\title{
La diversidad animal de España
}

\author{
Miguel Lizana' \\ José Luis Viejo
}

Sumario: I. INTRODUCCIÓN. II. LA DIVERSIDAD ANIMAL EN EL PLANETA. III. ¿CUÁNTAS ESPECIES ANIMALES EXISTEN EN ESPAÑA?. IV. LA DIVERSIDAD DE INVERTEBRADOS. 1. Poríferos. 2. Cnidarios. 3. Platelmintos. 4. Moluscos. 5. Anélidos. 6. Equinodermos. V. LOS VERTEBRADOS ESPAÑOLES. 1. El concepto geográfico y administrativo de España. 2. La diversidad de ecosistemas y hábitats en España. 3. El estado de conservación de los vertebrados españoles. VI. Los peces continentales españoles. 1. Los peces exóticos introducidos. VII. LA HERPETOFAUNA ESPAÑOLA. 1. Los anfibios españoles. 2. Los reptiles españoles. 3. Estado de conservación de los reptiles según las categorías UICN. 4. Los anfibios y reptiles introducidos en España. VIII. LAS AVES ESPAÑOLAS. 1. La importancia de Baleares y Canarias. 2. El estado de conservación de las aves españolas. IX. LOS MAMíFEROS ESPAÑOLES. 1. LAS ESPECIES INTRODUCIDAS. 2. LAS ESPECIES EMBLEMÁTICAS Y SU ESTADO DE CONSERVACIÓN. 3. LAS ESPECIES DE CAZA MAYOR. X. REFERENCIAS BIBLIOGRÁFICAS. XI. AGRADECIMIENTOS.

\section{INTRODUCCIÓN}

Biodiversidad o diversidad biológica es un neologismo compuesto de los términos bio (vida) y diversidad. Las raíces del concepto se encuentran en los trabajos de ecólogos que propusieron los primeros índices destinados a comparar la diversidad interna de los ecosistemas. El concepto más en boga, el de "biodiversidad" fue acuñado por Thomas Lovejoy en 1980, pero lo popularizó el entomólogo y divulgador Edward Wilson en 1986, sustituyendo al de diversidad biológica, menos eficaz desde el punto de vista de la comunicación. Desde 1986 el uso del término se ha extendido entre biólogos, ecologistas, dirigentes políticos y ciudadanos en general.

1 Profesor titular de Zoología. Universidad de Salamanca.

2 Catedrático de Zoología. Universidad Autónoma de Madrid. 
La definición más utilizada de Biodiversidad o Diversidad Biológica (a partir de ahora BD) es la que procede del Artículo 2 del Convenio sobre la Diversidad Biológica de Río de Janeiro (Brasil): "La variabilidad entre los organismos vivos, incluyendo los terrestres, marinos y de otros ecosistemas acuáticos, así como los complejos ecológicos de los que forman parte; esto incluye la diversidad dentro de las especies, entre especies y en los ecosistemas". De un modo resumido, se ha descrito como "la "totalidad de genes, especies, y ecosistemas de una región".

La biodiversidad tiene tres niveles principales: la diversidad genética, la diversidad de especies y la diversidad de ecosistemas. La primera alude tanto a la variación genética entre los distintos individuos de una población de organismos, como a la disparidad (variación) genética entre diferentes poblaciones de la misma especie. Este concepto, aunque de capital importancia, es con frecuencia difícil de esclarecer y no suele ser motivo de debate fuera de los medios estrictamente científicos. Muy distinto es lo que sucede con la diversidad de especies, que acapara el debate público y que es el nivel de la biodiversidad al que se presta más atención; la diversidad de especies a menudo se conoce como riqueza de especies. Por último, la diversidad de ecosistemas se refiere al número y variedad de sistemas biológicos (ecosistemas) que se pueden hallar en una determinada zona del planeta; este importantísimo componente de la biodiversidad ciertamente recibe atención tanto desde el ámbito de la ciencia ecológica, como de las instituciones públicas, si bien no termina de calar (como la diversidad genética) en la opinión pública; además, la atención que recibe, en tanto que análisis, debate y protección (en un plano puramente teórico, por desgracia) es considerablemente superior en los ámbitos internacionales que en los más locales, lo que no contribuye a su conservación. La conservación de la biodiversidad afecta por igual a los tres niveles, y olvidar o preterir cualquiera de ellos supondrá un fracaso en los planes o políticas referidos a su protección.

En este artículo nos vamos a referir principalmente al segundo nivel de la biodiversidad, es decir, a la diversidad de especies, en este caso, animales, pero queremos dejar claro desde el principio la indisoluble relación entre los tres niveles. Hay que recordar, sin embargo, que el número de especies de una zona también depende del concepto de "especie" que consideremos. En general, se hace referencia a un concepto "evolutivo o clásico" de especie. Si se aplicara un concepto más amplio, como el filogenético o cladista, el número de especies se multiplicaría, como ha sucedido en algunos estudios recientes sobre aves o murciélagos norteamericanos.

En este trabajo nos referiremos por tanto al concepto de especie evolutivo tradicional, sin entrar en niveles taxonómicos inferiores, como el de subespecie o poblacional. Las subespecies suponen una variabilidad genética que tienen una gran importancia a la hora de la conservación de poblaciones diferenciadas genética o geográficamente, pero esto excede el alcance de este trabajo.

El concepto “diversidad” tiene, en Ecología, unas connotaciones bastante específi40 cas. Por eso algunos ecólogos se han resistido a emplear alguno de estos términos. En 
cualquier caso, “diversidad” (en ecología), o “diversidad ecológica”, con sus diversos índices, alfa, beta y gamma no es lo mismo que "biodiversidad" o "diversidad biológica".

Como ya plantearon Darwin y Wallace hace siglo y medio, en términos generales, la diversidad biológica en los ecosistemas terrestres, entendida como diversidad de especies, disminuye con la latitud; dicho de otro modo, a medida que nos aproximamos a los trópicos o al Ecuador aumenta la riqueza de especies. Este gradiente se debe, entre otras razones, a la historia evolutiva y al clima; las comunidades tropicales son en general evolutivamente "más antiguas" que las boreales o australes, y en las primeras las perturbaciones climáticas generales más infrecuentes; considérense por ejemplo las glaciaciones. Los dos factores climáticos que más se correlacionan con la biodiversidad son la radiación solar y la disponibilidad de agua, mucho más abundantes, de modo conjunto, en las áreas tropicales. Pero a medida que disminuimos la escala, encontramos más factores que influyen en la diversidad, como el área de la zona considerada y la heterogeneidad ambiental derivada del relieve, la orientación de las montañas, la interacción con las actividades humanas, etcétera.

Pero... ¿Por qué nos preocupa tanto últimamente la biodiversidad? Probablemente porque la estamos perdiendo, y esta pérdida sin duda nos afecta en una amplísima gama de aspectos, el primero de los cuales podría ser la biofilia, término que, como el propio de biodiversidad, ha sido introducido por E.O. Wilson. La biofilia (literal y etimológicamente amor por la vida) es la innata inclinación, por una comprensible conexión, de los seres humanos hacia la naturaleza en general y hacia otras formas de vida en particular. La creencia de que otros organismos merecen vivir (o al menos sobrevivir) está en numerosas mitologías y religiones, si bien algunos de estos conceptos religiosos pueden haber contribuido también al expolio de la naturaleza, o al menos eso podría deducirse de las ideas platónicas que empapan la civilización y cultura judeo-cristianas: el Hombre como medida de todas las cosas. Pero es que además de estos aspectos biofílicos, la biodiversidad proporciona innumerables beneficios a los seres humanos, ya que muchas especies amenazadas podrían cultivarse o explotarse para la obtención de alimentos, fármacos, u otras materias primas. Se estima que al menos un $25 \%$ de las principios activos de la farmacopea moderna fueron originalmente descubiertos en las plantas, y eso sin contar con las medicinas de extracción vegetal directa que proporciona la farmacopea tradicional; la extinción de las especies acarrearía la pérdida de una fantástica fuente de medicamentos. Además de estos beneficios directos en forma de medicinas, alimentos, fibras textiles, herramientas, etcétera, la biodiversidad (o mejor, sus componentes) contribuye a unos esenciales servicios del ecosistema, que comprenden todos los procesos que permiten mantener la vida en el Planeta, tal y como la conocemos, y a la que pertenecemos los seres humanos, y entre los que podemos mencionar desde el mantenimiento y depuración de la atmósfera o la hidrosfera, hasta el reciclado de residuos o nutrientes, la polinización, la dispersión de semillas, el control de las plagas agrícolas o forestales, etcétera.

La principal amenaza de la biodiversidad es la acción humana sobre el Planeta, expresada en numerosas actividades que, genérica y básicamente, se pueden agru- 
par en cuatro: destrucción del hábitat, introducción de especies, sobreexplotación e intromisión en las redes ecológicas. Todas ellas están conectadas y a menudo unas llevan a otras; así, la destrucción de los bosques naturales (sean amazónicos, afrotropicales o del sudeste asiático) suele ser consecuencia de una sobreexplotación de los recursos madereros, que además supone con frecuencia la entrada de especies invasoras o la desaparición de especies clave en la dispersión de semillas o la polinización, como por ejemplo sucederá con las higueras (árboles del género Ficus) en relación con sus himenópteros Agaonidae polinizadores.

\section{LA DIVERSIDAD ANIMAL EN EL PLANETA}

La BD existente en la Tierra actualmente es el resultado de más de 4.000 millones de años de evolución. Durante mucho tiempo, ha sido un misterio conocer con exactitud cuántas especies animales se han descrito científicamente. Obsérvese que no decimos "especies animales existentes en la Tierra", ya que su número real es desconocido y sólo podemos aproximarnos mediante predicciones más o menos realistas. El conocimiento sobre la biodiversidad, en la que se incluye la diversidad animal, ha ido creciendo exponencialmente durante los últimos 200 años, desde que los naturalistas de la Ilustración desarrollaron sus trabajos de compilación y descripción, en particular Linneo (1758), quién con su Systema Naturae estableció el sistema binomial de clasificación, que se extendió rápidamente (May, 1988; Edwin, 1991; Wilson, 1992).

La pregunta de cuántas especies existen en la Tierra no tiene fácil respuesta, en gran medida a causa del enorme grado de incertidumbre de los datos manejados, lo cual a su vez es consecuencia de la carencia, escasez o imprecisión del conocimiento de numerosos grupos biológicos o de extensas áreas. Así, no se conocen por igual los animales que las plantas, los hongos o los protistas; y dentro de los primeros, la precisión de los datos es muy diferente entre los vertebrados que entre los insectos; y aún, entre los vertebrados, se conocen mucho mejor las aves que los peces, de manera que los datos que aparecen en la bibliografía, y los que vamos a dar en este artículo no dejan de ser aproximaciones, cuya exactitud además es muy dispar. En la tabla 1 mostramos el número de especies descritas y estimadas de los principales grupos de organismos vivientes (Heywood \& Watson, 1995); en ella se incluyen organismos de dudosa adscripción al mundo viviente, como los virus, y organismos en los que el concepto de especie es asimismo controvertido (bacterias).

La década de 1990 fue fundamental para la recopilación de los datos de la BD mundial. La Cumbre de la Tierra de Río de Janeiro de 1992 y el consiguiente Convenio de Biodiversidad desatacaron la necesidad de conocer y proteger la BD planetaria, con todos sus niveles y matices. Algunos libros como el de "Biodiversidad" de Edward O. Wilson (1992) pusieron las bases para el estudio rápido de la $\mathrm{BD}$, por ejemplo los short cuts o atajos, estudios intensivos en zonas de alta BD de todo el mundo que permitieran conocer la BD máxima y compararla entre zonas. Fruto de estos trabajos surgen datos más precisos. Dos

42 instituciones aportan información con un cierto detalle; la Unión Internacional para la 
Conservación de la Naturaleza (UICN en español, IUCN en inglés) y el World Conservation Monitoring Centre (WCMC) que han publicado periódicamente datos mundiales o regionales con el número de seres vivos y además su estado de conservación en el caso de la UICN. Groombridge et al (1992 a, b) ofrecieron la cifra de aproximadamente 1,75 millones de especies de seres vivos conocidas y descritas por la ciencia, de las cuales 1.300 .000 son animales. Las estimaciones del número total de seres vivos actuales (no extinguidos) varían entre 3,6 y 100 millones, siendo en torno a los 10 millones de especies el valor más aceptado. La mayoría de seres vivos pluricelulares son animales, sobre todo invertebrados, con 1,3 millones de especies, de las que 1,1 millones son especies descritas de insectos, y sólo unas 55.000 especies de vertebrados. De estos últimos 21.000 son peces, 5.000 son anfibios, 6.500 son reptiles, 8.700 son aves y 4.100 son mamíferos. Después de los animales, el segundo grupo de seres vivos más numeroso y bien conocido es el las plantas vasculares, con aproximadamente 250.000 especies. Los hongos aportan unas 70.000 especies. La diversidad de los microorganismos es poco conocida, pero sólo las diatomeas, mejor catalogadas gracias a su diversidad morfológica, suman casi 100.000 especies. Estos números crecen constantemente, ya que cada año se describen numerosas especies. La relación entre especies animales terrestres y marinas está ampliamente sesgada hacia las terrestres, con sólo unas 200.000 especies marinas. Es decir la mayor cantidad de BD, al menos en animales y plantas superiores, está en los ecosistemas terrestres.

\section{FIGURA 1}

Número de especies de los principales grupos de organismos. Tomado de Primack (1988) y Primack \& Ros (2002): Introducción a la biología de la conservación. Ed. Ariel, Barcelona

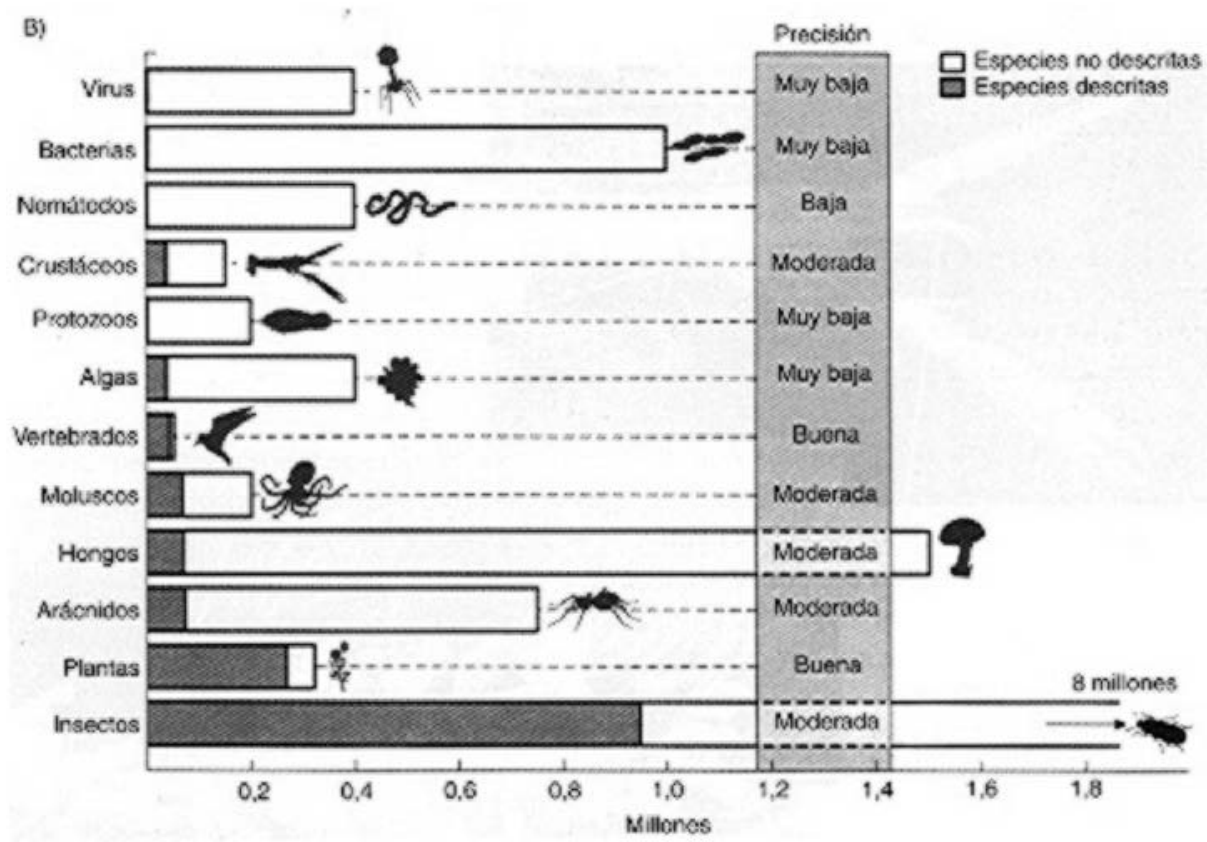


Sólo dos grupos de seres vivos, los vertebrados (55.000-60.000 especies) y las plantas superiores (230.000 especies), se consideran bien conocidos a nivel mundial, a pesar de que todos los años se descubren decenas o cientos de nuevos vertebrados en el mundo. Por supuesto, el número de Artrópodos e insectos conocidos crece casi por miles cada año. En términos generales, se estima que sólo se conoce un $5 \%$ de los hongos del mundo, o un 10\% de las bacterias, y numerosos taxa no han sido aun inventariados, como las bacterias, o la mayoría de los protistas (Meffe \& Carroll, 1997; Primack \& Ros, 2002; May, 2005; Wilson, 2005).

Al margen de consideraciones mucho más precisas, puede verse que de largo los artrópodos constituyen el grupo (en términos biológicos tronco o phylum) más numeroso, con más de un millón de especies descritas, y un número incomparablemente alto de especies por describir, que va desde la estimación más conservadora de unos dos millones y medio, hasta la más elevada de más de cien millones. Dada esta notable desproporción, dedicaremos un artículo separado a estos animales.

\section{TABLA 1}

Número de especies de los principales grupos de organismos*

\begin{tabular}{|c|c|c|c|c|c|}
\hline \multirow{2}{*}{ Organismos } & \multirow{2}{*}{$\begin{array}{c}\text { N. }{ }^{\circ} \text { de } \\
\text { especies } \\
\text { descritas }\end{array}$} & \multicolumn{3}{|c|}{ Número de especies estimadas } & \multirow{2}{*}{ Precisión } \\
\hline & & ALTO & BAJO & MEDIO & \\
\hline VIRUS & 4.000 & 1.000 .000 & 50.000 & 400.000 & Muy baja \\
\hline BACTERIAS & 4.000 & 3000000 & 50.000 & 1.000 .000 & Muy baja \\
\hline HONGOS & 72.000 & 2.700 .000 & 200.000 & 1.500 .000 & Moderada \\
\hline PROTOZOOS & 40.000 & 200.000 & 60.000 & 200.000 & Muy baja \\
\hline ALGAS & 40.000 & 1.000 .000 & 150.000 & 400.000 & Muy baja \\
\hline PLANTAS & 270.000 & 500.000 & 300.000 & 320.000 & Buena \\
\hline NEMATODOS & 25.000 & 1.000 .000 & 100.000 & 400.000 & Baja \\
\hline \multicolumn{6}{|l|}{ ARTRÓPODOS } \\
\hline CRUSTÁCEOS & 40.000 & 200.000 & 75.000 & 150.000 & Moderada \\
\hline ARÁCNIDOS & 75.000 & 1.000 .000 & 300.000 & 750.000 & Moderada \\
\hline INSECTOS & 950.000 & 100.000 .000 & 2.000 .000 & 8.000 .000 & Moderada \\
\hline MOLUSCOS & 70.000 & 200.000 & 100.000 & 200.000 & Moderada \\
\hline CORDADOS & 45.000 & 55.000 & 50.000 & 50.000 & Buena \\
\hline OTROS & 115.000 & 800.000 & 200.000 & 250.000 & Moderada \\
\hline TOTAL & 1.750 .000 & 111.655 .000 & 363.5000 & 13.620 .000 & Muy baja \\
\hline
\end{tabular}

44 * Modificado de Heywood \& Watson, 1995. 
En lo que concierne a los animales, puede observarse que el nivel de conocimiento taxonómico, es decir de las especies (u otros taxones) es muy desigual y desde luego está lejos de acercarse a la diversidad total; en este sentido, cabe mencionar a los nematodos (gusanos redondos) como el tronco que, en términos relativos, más incertidumbre ofrece, aunque son los artrópodos los que en términos generales menos conocemos; por el contrario, los cordados son los mejor conocidos y de los que no es verosímil que en el futuro se descubra un número de especies significativamente alto.

\section{III. ¿CUÁNTAS ESPECIES ANIMALES EXISTEN EN ESPAÑA?}

Los límites de las entidades geopolíticas, como son los estados, no siempre coinciden con los de las unidades biogeográficas, más aún, lo habitual es que no lo hagan, de manera que hablar de la "fauna española" tiene escaso sentido biogeográfico, por más que sea una expresión útil desde otros puntos de vista. Recuérdese que la pertenencia al Estado Español de diversos territorios separados de la unidad geográfica continental (más bien deberíamos decir peninsular) hace que sean tan "españoles" (término más bien jurídico en este caso) las aves de la Sierra de la Demanda, como los reptiles de Chafarinas o los escarabajos del Teide. Así, tendremos que diferenciar en este artículo, las especies genuinamente peninsulares de las baleares (con frecuencia casi idénticas a las anteriores), las canarias o las norteafricanas (Alborán, Chafarinas, Ceuta, Melilla y diversos otros enclaves).

Desde el punto de vista biogeográfico, el territorio español se encuentra situado en la región Paleártica, en concreto en su extremo occidental, y presenta dos grandes unidades faunísticas diferentes: el área ibero-balear y las islas Canarias. En relación con la península Ibérica, el territorio puede dividirse en dos regiones: la Eurosiberiana y la Mediterránea, o lo que en términos coloquiales podemos definir como la España húmeda y la España seca. A ellas se añade la singularidad canaria, cuyo territorio pertenece a la región Macaronésica. Estas divisiones corresponden más bien a los animales terrestres, ya que la biogeografía marina es diferente, y establece tres regiones: Lusitánica, Mediterránea y Mauritánica. Como sucede en otras áreas geográficas, salvo los cordados, la mayoría de los grupos zoológicos españoles carecen de una estimación precisa y fiable de su amplitud taxonómica, por lo que tendremos que para valorar la riqueza faunística española tendremos que acudir necesariamente a aproximaciones y extrapolaciones.

En la tabla 2 mostramos el número aproximado e inferido de especies descritas en distintos espacios, y el porcentaje de diferentes grupos sobre el total. En los vertebrados se incluyen los peces continentales y marinos, y en las aves, sólo las residentes y nidificantes. Como vemos, la inmensa mayoría de las especies animales descritas son invertebrados, nombre que poco ayuda a la comprensión de la heterogeneidad que intenta agrupar. En el mundo, sólo el 3\% de las especies descritas son vertebrados, y el resto se incluye en el cajón de sastre de los invertebrados; es decir, el 97\% de 
los animales conocidos pertenecen a esta última categoría, y el 80\% son insectos. Los datos para España son parecidos. Dado que la fauna de vertebrados es la mejor conocida, y que la proporción entre el número de especies de insectos y de vertebrados (excluidos peces) es ligeramente superior al $80 \%$, se puede inferir que en España podría haber entre 46.000 y 48.000 especies de insectos (Ramos et al., 2002). Estas inferencias se complican en relación con los demás invertebrados, a pesar de lo cual se han propuesto cifras para la fauna española tales como unas 5.300 especies de artrópodos no insectos (arácnidos, crustáceos, miriápodos, etc.) y unas 4.900 del resto: esponjas, cnidarios, platelmintos, nematodos, anélidos, moluscos, equinodermos, etcétera (Ramos et al., 2002).

\section{TABLA 2}

Número aproximado e inferido de especies descritas*

\begin{tabular}{|c|c|c|c|c|c|}
\hline \multirow{3}{*}{$\begin{array}{l}\text { Grupo animal } \\
\text { Insectos }\end{array}$} & \multicolumn{2}{|c|}{ Mundo } & \multirow{2}{*}{$\begin{array}{c}\begin{array}{c}\text { Cuenca } \\
\text { Mediterránea }\end{array} \\
\text { Número de }\end{array}$} & \multicolumn{2}{|c|}{ Península Ibérica } \\
\hline & \multirow{2}{*}{$\begin{array}{c}\begin{array}{c}\text { N. }{ }^{\circ} \text { de } \\
\text { especies }\end{array} \\
1.110 .000\end{array}$} & \multirow{2}{*}{$\begin{array}{c}\% \\
79,6\end{array}$} & & pecies & $\%$ \\
\hline & & & 150.000 & 46.900 & 80,7 \\
\hline Artrópodos no insectos & 125.000 & 9 & 16.900 & 5.280 & 9,1 \\
\hline Otros invertebrados & 116.000 & 8,3 & 15.680 & 4.900 & 8,4 \\
\hline Vertebrados & 44.000 & 3,1 & 2.120 & 1.068 & 1,8 \\
\hline TOTAL & 1.395 .000 & 100 & 184.700 & 58.148 & 100 \\
\hline
\end{tabular}

* Incluye en distintos espacios, y porcentaje de diferentes grupos sobre el total. En los vertebrados se incluyen los peces continentales y marinos, y en las aves, sólo las residentes y nidificantes. Tomado de Ramos et al., 2002.

\section{LA DIVERSIDAD DE INVERTEBRADOS}

Como hemos comentado antes, los llamados invertebrados son un conjunto heterogéneo de taxones animales cuyo único nexo es una carencia: no tienen vértebras. Este término viene utilizándose desde hace dos siglos (fue Lamarck el que lo propuso, en 1809) y por más intentos de sustitución que se hayan hecho, no se ha encontrado un sustituto que defina a los aproximadamente 34 troncos de animales que no tienen vértebras. El resto de animales son los vertebrados, conjunto animal evolutivamente homogéneo y que se agrupa en un solo taxón (clado), que a su vez constituye una rama de un árbol evolutivo (los Cordados) en el que el resto de los clados agrupa a animales carentes de vértebras. Pues bien, los Cordados son el $35 .^{\circ}$ tronco (phylum) animal (por poner un orden que no significa nada en concreto) y agrupa tanto a vertebrados (peces, anfibios, reptiles, aves y mamíferos), como a in46 vertebrados (tunicados y cefalocordados). 
A continuación daremos un somero repaso a la diversidad de algunos de los grupos de invertebrados más relevantes, si bien, y dada la extraordinaria importancia de los artrópodos, dedicaremos un artículo entero a este tronco. Sólo nos extenderemos (y aún así brevemente) en los troncos de invertebrados con más de 5000 especies conocidas en el mundo. Dado que los invertebrados no artrópodos tienen en el mar su residencia ecológica principal, en la tabla 3 (Templado, 2006) mostramos la biodiversidad marina en términos generales, para que el lector se haga una idea de su magnitud y pueda comparar entre los diferentes grupos de organismos. Por otra parte, y debido a la creciente preocupación por la conservación de la fauna, en España se han ido incorporando diversas especies al Catálogo Nacional de Especies Amenazadas, lo que recogemos en las tablas 4 y 5 (MMARM, 2009).

\section{TABLA 3}

Biodiversidad marina*

\begin{tabular}{|l|c|c|c|c|c|}
\hline & Mundiales & Europeas & Mediterráneas & Españolas & Canarias \\
\hline ALGAS & 6.600 & 1684 & 980 & 1035 & 639 \\
\hline Clorofitas & 1.100 & 328 & 200 & 215 & 118 \\
\hline Feofitas & 1.500 & 437 & 260 & 270 & 130 \\
\hline Rodofitas & 4.000 & 919 & 520 & 550 & 391 \\
\hline ANGIOSPERMAS & 55 & 5 & 5 & 5 & 3 \\
\hline ANIMALES & 188.349 & $\mathbf{2 4 . 1 8 5}$ & $\mathbf{1 2 . 0 0 0}$ & 9.253 & 3.950 \\
\hline Poríferos & 9.000 & 1.640 & 590 & 550 & 157 \\
\hline * Placozoos & 2 & 2 & 2 & 1 & - \\
\hline * Mesozoos & 85 & 35 & 20 & $?$ & - \\
\hline Cnidarios & 10.000 & 1.329 & 730 & 650 & 164 \\
\hline * Ctenóforos & 110 & 38 & 30 & 30 & 4 \\
\hline Platelmintos & 15.000 & $2.398(?)$ & 900 & $?$ & 37 \\
\hline Rotíferos & 250 & 139 & 59 & 20 & - \\
\hline * Gnatostomúlidos & 80 & 25 & 10 & 4 & - \\
\hline Nemertinos & 750 & 478 & 187 & 45 & - \\
\hline * Gastrotricos & 400 & 237 & 165 & $?$ & - \\
\hline * Loricíferos & 10 & 2 & 2 & 1 & - \\
\hline * Kinorrincos & 120 & 37 & 28 & 5 & 1 \\
\hline Ciclióforos & 4 & 3 & 2 & 3 & - \\
\hline Nematomorfos & 10 & 3 & 1 & $?$ & - \\
\hline * Priapúlidos & 15 & 7 & 5 & 3 & - \\
\hline Nematodos & 12.000 & 1837 & 703 & $?$ & - \\
\hline Acantocéfalos & 200 & 67 & $?$ & $?$ & - \\
\hline & & & & & \\
\hline
\end{tabular}


TABLA 3 (cont.)

Biodiversidad marina*

\begin{tabular}{|c|c|c|c|c|c|}
\hline & Mundiales & Europeas & Mediterráneas & Españolas & Canarias \\
\hline * Entoproctos & 170 & 45 & 19 & 5 & - \\
\hline *Equiúridos & 140 & 19 & 6 & 5 & 2 \\
\hline *Sipuncúlidos & 160 & 44 & 33 & 35 & 6 \\
\hline Moluscos & 60.000 & 3.353 & 2.800 & 2.250 & 1.170 \\
\hline Anélidos & 12.000 & 2.074 & 1.100 & 1.000 & 305 \\
\hline *Pogonóforos & 120 & 23 & 5 & 3 & - \\
\hline Tardígrados & 120 & 76 & 60 & 20 & - \\
\hline Quelicerados & 1.000 & 361 & 275 & 190 & 12 \\
\hline Crustáceos & 38.000 & $6.522(?)$ & 2.600 & 2.500 & 1.095 \\
\hline Briozoos & 4.000 & 724 & 250 & 280 & 131 \\
\hline * Braquiópodos & 350 & $18(?)$ & 16 & 31 & 15 \\
\hline * Foronídeos & 16 & 9 & 8 & 8 & 2 \\
\hline * Quetognatos & 70 & 42 & 25 & 30 & 22 \\
\hline * Hemicordados & 90 & 17 & 5 & 5 & - \\
\hline * Equinodermos & 7.000 & 648 & 230 & 275 & 82 \\
\hline Cordados & 17.123 & 1.933 & 921 & 1.532 & 745 \\
\hline (*Urocordados) & 2.100 & 481 & 320 & 350 & 28 \\
\hline (* Cefalocordados) & 23 & 2 & 1 & 2 & - \\
\hline (Vertebrados) & 15.000 & 1.450 & 900 & 1.180 & 717 \\
\hline Totales & $\cong 195.000$ & 25.871 & $\cong 13.000$ & $\cong 10.300$ & 4.592 \\
\hline
\end{tabular}

* Número de especies de los distintos grupos vegetales y animales a nivel mundial, europeo, mediterráneo, español (incluyendo Canarias) y canario. Tomado de Templado, 2006.

Se han señalado con un asterisco los grupos exclusivamente marinos. Los números de especies mundiales, mediterráneas y españolas son estimativos o aproximados y se refieren a especies descritas y citadas (no a especies posibles). En muchos casos el número de especies citadas es muy inferior al real, debido a un deficiente conocimiento del grupo en ese área geográfica. Las interrogaciones en la columna de las especies españolas se refieren a aquellos grupos cuyo número de especies citadas se considera inferior al $5 \%$ de las que deben existir. Por otro lado, 48 los números que se consignan en las columnas de especies europeas y canarias no 
son estimativos, sino que corresponden con exactitud a los que figuran en el European Register of Marine Especies (Costello et al., 2001) y a las recogidas en el "Proyecto BIOTA" (Moro et al., 2003), respectivamente. En lo que se refiere a la lista de especies europeas, los números referentes a los platelmintos y a los crustáceos están sobredimensionados, posiblemente por haberse incluido también las as especies no marinas (esto claramente sucede con los isópodos, dentro de los crustáceos, y con los grupos parásitos, dentro de los platelmintos). Por el contrario, la cifra de braquiópodos parece subestimada, pues el número de especies citadas de este grupo en los mares europeos debe ser próxima a 40. De cara a llamar la atención sobre ello, se ha puesto una interrogación a continuación de las cifras dadas para estos grupos.

\section{TABLA 4}

Número de taxones (especies y subespecies) incluidos por Categorías de Amenaza en el Catálogo Nacional de Especies Amenazadas

\begin{tabular}{|c|c|c|c|c|c|}
\hline Grupo & $\begin{array}{c}\text { En } \\
\text { peligro de } \\
\text { extinción }\end{array}$ & $\begin{array}{l}\text { Sensible a la } \\
\text { alteración de } \\
\text { su hábitat }\end{array}$ & Vulnerable & $\begin{array}{l}\text { De interés } \\
\text { especial }\end{array}$ & Total \\
\hline TOTAL & $166^{*}$ & $21^{*}$ & $61 *$ & $363^{*}$ & $\begin{array}{c}611^{*} \\
602 \text { taxones }\end{array}$ \\
\hline FLORA & $112^{*}$ & $7^{*}$ & $9^{*}$ & 11 & $\begin{array}{c}139^{*} \\
137 \text { taxones }\end{array}$ \\
\hline INVERTEBRADOS & 16 & 7 & 9 & 10 & $\begin{array}{c}42 \\
42 \text { taxones }\end{array}$ \\
\hline No Artrópodos & 4 & 1 & 4 & 1 & 10 taxones \\
\hline Artrópodos & 12 & 6 & 5 & 9 & 32 taxones \\
\hline VERTEBRADOS & $38^{*}$ & $7 *$ & $43^{*}$ & $342^{*}$ & $\begin{array}{c}430 * \\
423 \text { taxones }\end{array}$ \\
\hline Peces & 4 & 0 & 6 & 1 & $\begin{array}{c}11 \\
11 \text { taxones }\end{array}$ \\
\hline Anfibios & 1 & 0 & 1 & 20 & $\begin{array}{c}22 \\
22 \text { taxones }\end{array}$ \\
\hline Reptiles & 5 & 3 & 1 & 42 & $\begin{array}{c}51 \\
51 \text { taxones }\end{array}$ \\
\hline Aves & $21^{*}$ & 3 & $12^{*}$ & $251^{*}$ & $\begin{array}{c}287^{*} \\
283 \text { taxones }\end{array}$ \\
\hline Mamíferos & 7 & $1^{*}$ & $23^{*}$ & $28 *$ & $\begin{array}{c}59^{*} \\
56 \text { taxones }\end{array}$ \\
\hline
\end{tabular}

Fuente: MMARM, 2009. 
TABLA 5

Lista de especies de invertebrados no artrópodos incluidas en el Catálogo Nacional de Especies Amenazadas

\begin{tabular}{|l|c|}
\hline \multicolumn{1}{|c|}{ Especie o subespecie } & Categoría \\
\hline Margaritifera auricularia (Spengler, 1793) & En peligro de extinción \\
\hline Patella candei candei (D’Orbigny) & En peligro de extinción \\
\hline Theodoxus velascoi (Graells, 1846) & En peligro de extinción \\
\hline Patella ferruginea (Gmelin, 1791) & En peligro de extinción \\
\hline Asterina pancerii (Gasco, 1870) & Vensible a la alteración de su hábitat \\
\hline Pinna nobilis (Linnaeus, 1757) & Vulnerable \\
\hline Charonia lampas lampas (Linnaeus, 1758) & Vulnerable \\
\hline Dendropoma petraeum (Monterosato, 1884) & Vulnerable \\
\hline Astroides calycularis (Pallas, 1766) & De interés especial \\
\hline Centrostephanus longispinus (Philippi, 1845) & \\
\hline
\end{tabular}

Fuente: MMARM, 2009.

\section{Poríferos}

No se conoce muy bien la fauna de poríferos (esponjas) de las aguas españolas, pero una cifra superior a las 700 especies no sería exagerada. En el mundo se han descrito unas 9000 especies. Se trata de animales marinos sencillos, que carecen de tejidos verdaderos, filtradores de plancton y bentónicos. Las esponjas producen diversas sustancias de carácter defensivo (antibióticos u otros) que pueden tener considerable interés en la industria farmacéutica.

\section{Cnidarios}

Los cnidarios son animales sencillos, aunque de estructura algo más compleja que las esponjas, que incluyen a organismos tan populares (o impopulares, según el punto de vista) como los pólipos y las medusas. La mayoría son marinos, aunque algunas formas son comunes en las aguas dulces, incluidos estanques y charcas, como Hydra. En el mundo se han descrito alrededor de 10000 especies, de las que en aguas españolas podrían encontrarse más de 800. En el Catálogo Nacional de Especies Amenazadas se ha incluido la especie Astroides calycularis (Anthozoa, Scleractinia, Dendrophyllidae); se trata de una madrépora muy llamativa por el color naranja de los pólipos que forman la colonia; en las costas españolas se puede encontrar desde

50 el Cabo de Palos hasta el mar de Alborán y el entorno del Estrecho. 


\section{Platelmintos}

Los platelmintos son gusanos planos que carecen de cavidad corporal y sistema circulatorio; incluyen unas 20000 especies, entre las que están las planarias (turbelarios), las duelas (trematodos) y las tenias (cestodos), entre otros. Poco se sabe de la fauna española de platelmintos, que podría estar constituida por cerca de un millar de especies. Algunas especies tienen considerable importancia médica o veterinaria, dado que causan enfermedades a los seres humanos o los animales domésticos; en este sentido podemos mencionar entre los trematodos la duela del hígado (Fasciola hepatica), presente en España, o la esquistosomiasis, producida por Schistosoma, ausente de España; entre los cestodos se incluyen las tenias, algunas de las cuales afectan gravemente a los seres humanos, como el quiste hidatídico.

\section{Moluscos}

Se conocen unas 93000 especies de moluscos en el mundo, de las que en España podría haber cerca de 5 000. Los moluscos son invertebrados conocidos y populares, con el cuerpo blando que con frecuencia protegen con una concha. Presentan tanto especies marinas, como dulceacuícolas e incluso terrestres, entre las que se pueden mencionar los gasterópodos (caracoles y babosas), los bivalvos (almejas, ostras y mejillones), los cefalópodos (pulpos, calamares y sepias) y los poliplacóforos (quitones). Además de su enorme importancia en los ecosistemas, los moluscos constituyen un destacado grupo zoológico desde el punto de vista de la alimentación humana, tanto por sus pesquerías (cefalópodos), como por su cultivo (mejillones, berberechos, almejas y ostras). Desde el punto de vista de la conservación podemos decir que los moluscos son un grupo relativamente amenazado, en particular los gasterópodos terrestres. Según el Libro Rojo de los Invertebrados de España (Verdú y Galante, 2006) en España se han catalogado 95 especies con problemas de conservación, de las cuales 89 son gasterópodos y 6 son bivalvos; la mayoría de los gasterópodos amenazados son pulmonados, es decir, caracoles terrestres, ya que aportan 69 especies a la lista roja. Entre las especies de moluscos amenazados podemos destacar las siguientes:

- Margaritifera auricularia, una almeja de río (náyade) en peligro de extinción, que sobrevive en contados lugares del río Ebro y del Canal Imperial de Aragón. Entre las principales causas de la extinción de las náyades están la alteración o destrucción del hábitat (ríos), la disminución o extinción de los peces a los que se asocian las larvas, la sobreexplotación por la búsqueda del nácar, y la introducción de especies exóticas. Otra náyade también amenazada en España es Margaritifera margaritifera, si bien no está tan restringida y aparece en algunos puntos de los ríos del noroeste peninsular (Aarujo, 2006).

- Belgrandiella edmundi, un pequeño gasterópodo de la familia de los hidróbidos, propio de manantiales de la isla de Mallorca, y considerado en peligro de 
extinción. Una especie próxima, Belgrandiella galaica, sólo conocida de O Courel (Lugo), está catalogada en peligro crítico. También en peligro de extinción se halla otro hidróbido, Spathogyna fezi, de manantiales de Cuenca y Castellón, o Tarraconia rolani, de manantiales de Tarragona (Arconada et al., 2006).

- Melanopsis penchinati, un gasterópodo de la familia Melanopsidae, endémico de surgencias termales de los alrededores de Alhama de Aragón (Zaragoza), y catalogado como en peligro crítico (Martínez-Ortí et al., 2006 a).

- Theodoxus boeticus, gasterópodo de la familia Neritidae, catalogada en peligro de extinción, y que aparece en fuentes y manantiales de la Comunidad Valenciana, Murcia y Andalucía Oriental. Theodoxus valentinus y Theodoxus velascoi, de surgencias próximas al río Verde (Valencia), están catalogadas en peligro crítico (Martínez-Ortí et al., 2006 b).

- Napaeus isletae, gasterópodo pulmonado de la familia Enidae, es un endemismo de Gran Canaria y está catalogado como en peligro crítico. Otros pulmonados amenazados son: Sculptiferussacia clausiliaeformis, propio de la península de Jandía (Fuerteventura), considerado en peligro de extinción; Hemicycla paeteliana, familia Helicidae, también de Jandía, en peligro de extinción; Hemicycla plicaria, de Tenerife, en peligro de extinción; Hemicycla saulcyi, de Gran Canaria, en peligro de extinción; y Canariella eutropis (familia Hygromiidae), de Jandía, en peligro de extinción (Ibañez y Alonso, 2006).

Otros moluscos amenazados, que aparecen en el Catálogo Nacional de Especies Amenazadas, son:

- Patella candei (Gastropoda, Patellidae). Se trata de una lapa canaria considerada en peligro de extinción.

- Patella ferruginea. Otra lapa también considerada en peligro de extinción. En este caso la especie se extendía por las costas del mar de Alborán, pero en la actualidad su distribución está muy mermada y sólo existen poblaciones viables en la orilla meridional, es decir, Ceuta, Melilla, islas Chafarinas, etc. (Templado et al., 2004).

- Pinna nobilis. Es un bivalvo endémico del Mediterráneo, de la familia Pinnidae considerado vulnerable, y que se puede encontrar desde las costas de Cabo de Gata hasta el cabo San Antonio. Está asociado a las praderas de Posidonia oceánica (Templado et al., 2004).

- Charonia lampas. Se trata de un gasterópodo Cymatiidae, conocido como caracola o bucino, incluido en el Catálogo con la categoría de vulnerable. Su área de distribución incluye gran parte del litoral español, aunque sus poblaciones 52 son realmente escasas (Templado et al., 2004). 
- Dendropoma petraeum. Es un gasterópodo vermétido, cuya concha no está enrollada en espiral, sino que presenta la forma de un tubo sinuoso que queda adherido al sustrato o a otros tubos semejantes, para formar auténticos conglomerados de consistencia rocosa, gracias también a un alga calcárea incrustante (Templado et al., 2004). Esta especie está catalogada como vulnerable. Su conservación es doblemente importante, ya que a su mero interés zoológico, se une la comunidad cuyo desarrollo permiten los conglomerados rocosos y porosos, a veces conocidos como arrecifes de vermétidos, y que aparecen en mares tropicales o subtropicales; esta especie es endémica del Mediterráneo, con escasos enclaves en las cotas atlánticas de Cádiz y de Marruecos.

\section{Anélidos}

Son animales de aspecto vermiforme. Presentan una conspicua segmentación, tanto externa como interna, y sedas quitinosas. Este tronco se divide en tres grandes grupos o clases: Poliquetos (en su mayor parte marinos), Oligoquetos (lombrices de tierra, la mayoría edáficas y unas pocas de agua dulce y estuarinas) e Hirudíneos (sanguijuelas, ectoparásitros de agua dulce, con algunas excepciones marinas). En total, los Anélidos comprenden unas 13000 conocidas a nivel mundial, de las que unas 9.000 son poliquetos. Estos últimos son los gusanos marinos más abundantes en todo tipo de hábitats. En España es un grupo bien estudiado del que se conocen unas 1000 especies. Dentro de los Oligoquetos, han sido bien estudiadas las lombrices de tierra, Lumbricidae, con unas 100 especies citadas, pero otras familias con muy numerosas especies, como los enquitreidos, son mal conocidas, pero las especies presentes en nuestros suelos y riberas de los ríos pueden superar las 200. Además, se han citado en nuestras aguas 28 de hirudíneos (dos de ellas marinas).

\section{Equinodermos}

Se caracterizan por una simetría radial. Las cerca de 7000 especies actuales conocidas son exclusivamente marinas y comprenden las comátulas o lirios de mar (Crinoideos), estrellas de mar (Asteroideos), ofiuras (Ofiuroideos), erizos (Equinoideos) y holoturias o pepinos de mar (Holoturoideos), además de un elevado número de formas fósiles. A pesar de que puede considerarse como un grupo relicto (más abundante en épocas pasadas que en la actualidad) y que su número de especies no es muy elevado en comparación con otros grupos, se trata de animales muy comunes en todo tipo de fondos marinos, desempeñan un importante papel ecológico y son muy utilizados para la caracterización de las diferentes comunidades bentónicas. Los erizos son los principales macroherbívoros de los fondos litorales y las estrellas se encuentran entre los principales depredadores, tanto en sustratos duros como sedimentarios. A pesar de ser un grupo bien conocido a nivel general, en nuestras costas han sido insuficientemente estudiados. En aguas españolas se conocen cerca de 300 especies. 
En el Catálogo Nacional de Especies Amenazadas se incluyen dos equinodermos: Asterina pancerii y Centrostephanus longispinus. El primero es un asteroideo conocido como "estrella del capitán pequeña", endémico del Mediterráneo, y que en las costas españolas sólo se ha encontrado en Cabo de Palos (Murcia), Agua Amarga (Almería), Bahía de Palma de Mallorca, Ibiza e islas Columbretes (TEMPLADO et al., 2004). Está catalogado como sensible a la alteración de su hábitat. Centrostephanus longispinus es un erizo de mar (Equinoideos) conocido como "puercoespín marino"; en España se encuentra la subespecie nominal, cuya área de distribución abarca parte del Atlántico oriental y el Mediterráneo; en aguas españolas se halla en algunos enclaves de la costa mediterránea y de la zona de Gibraltar. Se le asigna la categoría de interés especial.

\section{LOS VERTEBRADOS ESPAÑOLES}

Es casi un tópico decir que España tiene la mayor BD de Europa. Lo podemos leer tanto en trabajos de divulgación y científicos, como en informes políticos regionales, nacionales, de ONGs o de la propia Unión Europea. Sin embargo, para un zoólogo, es sorprendente comprobar la escasez de datos "reales" y confirmados, distintos de las estimaciones, acerca del número de animales tanto en el ámbito mundial, como en el regional (europeo) o incluso español.

También es sorprendente comprobar cómo la información más o menos precisa sobre el número de especies españolas es muy reciente y puede seguirse su evolución en diversos trabajos e informes, con un notable aumento en las últimas décadas en la riqueza española de especies, debido sobre todo al mayor conocimiento. Desde los datos muy básicos del ICONA en los años 80 del siglo XX, los mucho más precisos utilizados en la Estrategia española de conservación de la BD (aproximadamente 1994) y la excelente información recogida en los diversos capítulos del libro "la diversidad biológica de España” (Díaz Pineda et al, 2002 o los capítulos del libro "La Naturaleza en España", del Ministerio de Medio Ambiente, coordinado por Asensio (2002).

Los datos existentes en los atlas de vertebrados del Ministerio de Medio Ambiente (años 2002 a 2007) son ya mucho más precisos pues recogen la descripción de numerosas especies, sobre todo en el caso de los peces continentales y herpetos. Esta información, aunque en general demasiado sucinta, se actualiza en los informes anuales del Ministerio de Medio Ambiente (Perfil Ambiental de España, 2004 a 2008; Cuarto informe de Biodiversidad, 2009, etc.) basados en los sistemas de indicadores ambientales, en este caso de la BD española.

Entre las distintas iniciativas para tener unos datos precisos de la BD animal española, debemos resaltar el proyecto "Fauna Ibérica" (Museo Nacional de Ciencias Naturales-(SIC) que ha servido para actualizar la información, mediante una serie de valiosas monografías, particularmente de grupos de invertebrados y de algunos gru54 pos de vertebrados como los anfibios y reptiles. A pesar de este esfuerzo, es sorpren- 
dente el desconocimiento del número de especies para diversos grupos de invertebrados (Ramos et al., 2002), basado en muchos casos en estimaciones y comparaciones con otros países mediterráneos (ver Díaz Pineda et al., 2002). Es improbable que esta tendencia cambie, dada la disminución de especialistas en todo el mundo y en España en grupos de invertebrados. Por un lado, la creencia de que estos especialistas son innecesarios en un mundo científico de promoción de los taxónomos y biólogos moleculares, la reducción de gastos en ciencias como la taxonomía, etc. No olvidemos que sin especialistas en cada grupo ni siquiera podremos identificar a las especies, por muchos magníficos taxónomos moleculares que tuviéramos. Es imposible proteger la BD si no se conoce adecuadamente.

\section{El concepto geográfico y administrativo de España}

El territorio español se compone de la parte española de la península Ibérica, los archipiélagos Balear y Canario y las plazas de soberanía del norte de África: Ceuta, Melilla, los peñones de Vélez de la Gomera y Alhucemas y las islas Chafarinas (que suelen denominarse territorios transfretanos).

La superficie de España es de aproximadamente 500.000 km2. Su posición geográfica la convierte en una de las principales rutas migratorias para las aves europeas y en el pasado fue un refugio faunístico muy importante, como las otras penínsulas europeas, durante las glaciaciones. España ocupa un lugar a caballo entre varias regiones biogeográficas, lo que hace que su paisaje sea sumamente variado y complejo en el contexto europeo, pero tal diversidad ambiental no sólo se debe a la situación geográfica de la Península, sino que la orografía tiene mucho que ver en ello. Además, la cercanía a África y los contactos históricos, que influyen en la fauna ibérica aportando especies típicamente africanas.

Desde el punto de vista biogeográfico, en la Península se encuentran representadas las dos regiones principales de Europa occidental: la Mediterránea y la Eurosiberiana. En la Mediterránea se han delimitado cinco pisos bioclimáticos (termo, meso, supra, oro y criomediterráneo), mientras que en la Eurosiberiana encontramos cuatro (colino, montano, subalpino y alpino).

España es el segundo país europeo con mayor promedio de altitud (20\% del territorio tiene altitudes por encima de $1000 \mathrm{~m}$ ). En el norte se sitúan dos cadenas orográficas (cordillera Cantábrica y Pirineos), en el centro otras dos dividen la península Ibérica de este a oeste (Sistema Central y Sistema Ibérico) y en el sur la cadena bética y la sierra de Alcaraz suponen una nueva barrera hacia el sur. Estas montañas, y otras de menor altitud (dorsal Gallega, cordilleras Costeras Catalanas, Tramontana, Sierra Morena y Montes de Toledo), que delimitan los grandes espacios llanos (mesetas norte y sur) y a grandes depresiones producidas por los principales ríos que riegan la Península (Ebro, Duero, Tajo, Guadiana y Guadalquivir). Toda esta heterogeneidad de 
hábitats y relieves y su posición geográfica hacen de España un lugar privilegiado para la fauna.

El archipiélago canario está situado en el Atlántico y está compuesto por ocho islas: La Palma, El Hierro, Tenerife, Gran Canaria, Fuerteventura, Lanzarote y La Graciosa y grupos de islotes y roques. La superficie total de tierras emergidas es de 7490 km2. El Archipiélago presenta numerosos endemismos animales y vegetales y está considerado como un Área de Aves Endémicas (Endemic Bird Area, EBA), de importancia para la herpetofauna y la mastofauna.

Un aspecto importante a tener en cuenta al hablar de la BD española es la dimensión geográfico-administrativa del Estado español. La islas Canarias forman sin ninguna duda parte de España, a pesar de encontrarse en territorio geográfico africano, Sin embargo, hace años la fauna de Ceuta, Melilla y otros territorios españoles en el Norte de África (territorios transfretanos) no se contabilizaba como parte de la fauna “española”. Actualmente, sí se consideran estos datos y por tanto el Estado español tiene la misma responsabilidad sobre estas especies que en el resto del territorio español. Sólo en los últimos años, aproximadamente a partir del año 2000, se empiezan a recoger los datos de la biodiversidad de estos territorios, incrementando así notablemente el número de especies españolas.

Por otro lado, cuando comparamos la BD española con la europea, debemos de considerar los límites geográficos de Europa; cuando la BD española se comparaba con la Unión Europea de 12 países, la BD española era la mayor con mucha diferencia. Si consideramos 17 estados o en la actualidad 27, las cifras cambian ligeramente, pero España sigue siendo el país de mayor BD animal y vegetal seguido de otros estados mediterráneos de una superficie similar como Francia, Grecia o Italia; y en general el del mayor número de endemismos vegetales o animales, en gran medida por la aportación de Baleares y especialmente Canarias, Hay que tener en cuenta también la superficie de cada país, y así se obtienen los índices de riqueza de especies que tienen en cuenta la superficie de cada país. España sigue siendo el estado europeo con mayor índice de riqueza. Sólo un país, Turquía, a caballo entre Europa y Asia podría competir en BD con España.

En España es posible encontrar todavía una serie de especies ya desaparecidas (lobo, oso, águilas, quebrantahuesos, et) en otras naciones europeas. Ello es debido a que históricamente ha sido un territorio escasamente poblado si se lo compara con países como Alemania, Gran Bretaña o Italia, todos ellos de menor extensión, y a la tardía industrialización, que hizo que el declive de numerosas especies y la extinción de algunas otras fuera un fenómeno documentado a lo largo del siglo XX. También hay que destacar la gran cantidad de especies presentes debido a la influencia de la fauna africana (camaleón común, corredor, erizo moruno, gineta, calamón, melonciIlo, etc.) y el número de endemismos presentes en las islas Baleares (ferreret, pardela balear) y Canarias (palomas de la laurisilva, perenquén, Crocidura canariensis, hubara, 56 tarabilla canaria, halcón tagarote). 
TABLA 6

Número de especies descritas y número de especies endémicas para los cuatro grupos de vertebrados mejor conocidos en los países europeos con una biodiversidad más alta

\begin{tabular}{|c|c|c|c|c|c|}
\hline \multirow{2}{*}{ País } & \multicolumn{5}{|c|}{ Número de especies } \\
\hline & Mamíferos & Peces & Reptiles & Anfibios & Total \\
\hline España & 118 & 368 & 56 & 26 & 568 \\
\hline Italia & 118 & 232 & 58 & 38 & 446 \\
\hline Francia & 93 & 267 & 32 & 32 & 424 \\
\hline Grecia & 95 & 244 & 51 & 15 & 405 \\
\hline Ex-Yugoslavia & 95 & 245 & 41 & 23 & 404 \\
\hline Rumania & 84 & 249 & 25 & 19 & 377 \\
\hline Bulgaria & 81 & 242 & 33 & 17 & 373 \\
\hline Alemania & 76 & 237 & 12 & 20 & 345 \\
\hline Austria & 83 & 227 & 14 & 20 & 344 \\
\hline Ex-Checoslovaquia & 81 & 227 & 12 & 19 & 339 \\
\hline Albania & 68 & 215 & 31 & 13 & 327 \\
\hline \multirow[t]{2}{*}{ Portugal } & 63 & 214 & 29 & 17 & 323 \\
\hline & \multicolumn{5}{|c|}{ Número de especies endémicas } \\
\hline España & 12 & 5 & 19 & 9 & $45(7,92)$ \\
\hline Italia & 4 & 0 & 3 & 12 & $19(4,26)$ \\
\hline Francia & 0 & 9 & 0 & 3 & $12(2,83)$ \\
\hline Grecia & 2 & 0 & 4 & 1 & $7(1,73)$ \\
\hline Reino Unido & 0 & 13 & 0 & 0 & $13(1,50)$ \\
\hline Portugal & 1 & 2 & 1 & 0 & $4(1,24)$ \\
\hline Ex-Yugoslavia & 2 & 0 & 2 & 0 & $4(0,99)$ \\
\hline
\end{tabular}

Fuente: Informe Dobris (2003).

2. La diversidad de ecosistemas y hábitats en España³

En la Península Ibérica existen dos grandes zonas bioclimáticamente bien diferenciadas: el dominio eurosiberiano y el mediterráneo, con sus correspondientes

3 Este apartado se basa fundamentalmente en el Perfil Ambiental de España (2007, 2008) y en el Cuarto informe nacional sobre la diversidad biológica española del Ministerio de Medio Ambiente, Medio Rural y Marino (2009). 
áreas de transición. El norte y el noroeste (es decir la porción más septentrional de Portugal, Galicia, la cornisa cantábrica y la región pirenaica) son similares a gran parte del resto de Europa, con un clima templado caracterizado por un invierno húmedo y frío y lluvias durante el verano, con generalmente bosques caducifolios. El resto de la península soporta un régimen climático mediterráneo, caracterizado por inviernos suaves y lluviosos, y veranos cálidos y secos. Es la zona ocupada por el bosque y matorral mediterráneos.

El territorio español de la Península Ibérica, Norte de África e Islas Baleares se sitúa en la región mediterránea, y el archipiélago canario se sitúa en la Región Macaronésica. La región Mediterránea es uno de los, al menos, 25 "hotspots" o puntos calientes de biodiversidad que existen en el mundo (Oosterbroek, 1994; Myers et al., 2000). Estos puntos se definen no sólo por su BD total sino por el número de vertebrados y plantas endémicos de la zona. En la región existen 22.500 plantas vasculares endémicas, 9 aves, 11 mamíferos, 14 anfibios, todos ellos endémicos de la región y amenazados, y 5 especies extintas. Entre la fauna de mayor interés podemos citar al lince ibérico y al macaco de Berbería (Gibraltar). La región mediterránea es por tanto un área de conservación prioritaria a nivel mundial. El sur de la península Ibérica y la región macaronésica tienen además una relevancia especial por su elevada diversidad y endemicidad.

FIGURA 2

La región Mediterránea, punto caliente de la BD. Tomado de Myers et al., 2000

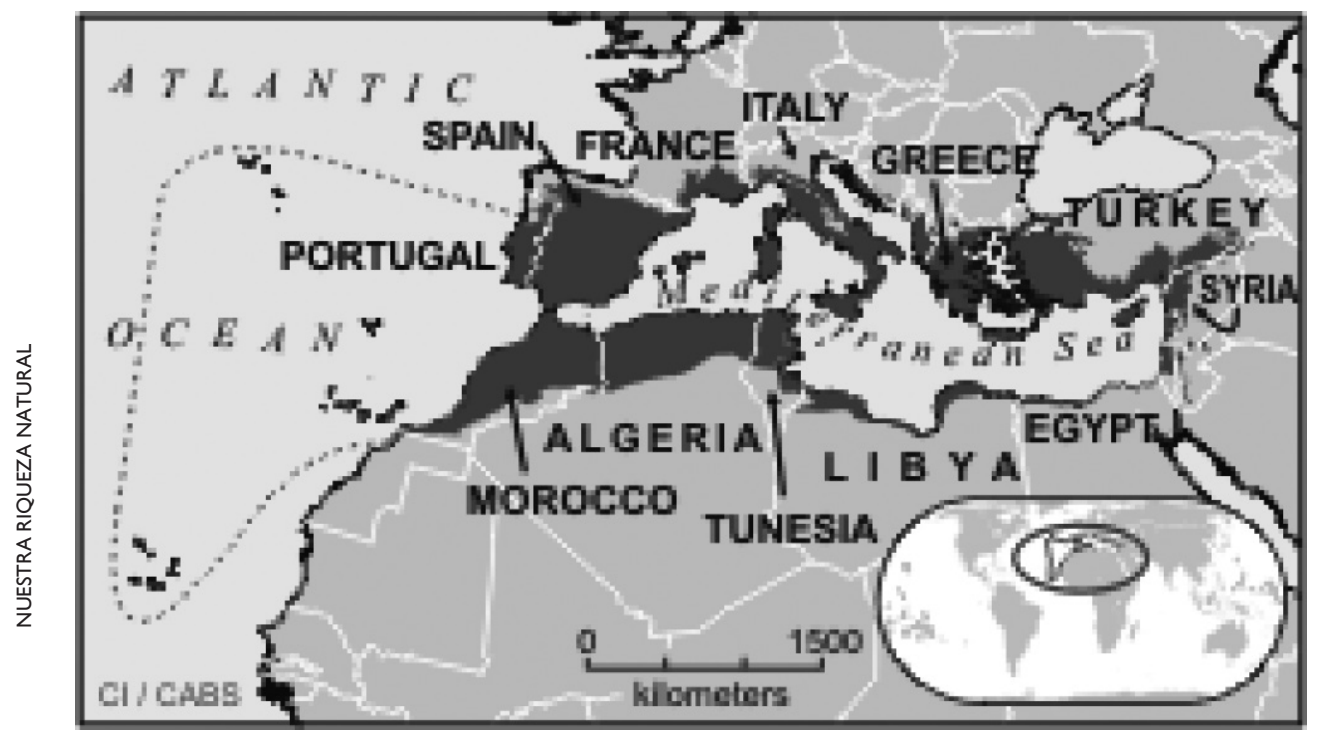


En el contexto de la Unión Europea, de los 197 tipos de hábitat de interés en este ámbito geográfico que recoge el anexo I de la Directiva "hábitats", unos 120 (aproximadamente el 60\%) se distribuyen en España, que participa de cuatro de las siete regiones biogeográficas definidas en la UE: mediterránea, atlántica, alpina y macaronésica. Entre esos hábitats, el $50 \%$ de los considerados prioritarios están bien representados en España. Así, España resulta ser uno de los países de más alta diversidad de hábitats naturales en la Unión Europea y, con gran diferencia, el país en donde estos hábitats ocupan todavía una mayor extensión.

Con respecto a los hábitat de interés recogidos en la Directiva “hábitats", el paisaje vegetal de España se muestra como un mosaico de formaciones arbóreas, arbustivas y herbáceas naturales, junto a cultivos agrícolas y repoblaciones forestales. A esto se añade una gran variedad de ecosistemas vinculados a los $8.000 \mathrm{~km}$ de costa, entre los que cabe destacar la zona intermareal, playas, acantilados, sistemas dunares, saladares y estepas salinas, etc. Por otra parte España es también rica en hábitats de agua dulce, con $75.000 \mathrm{~km}$ de ríos y al menos 1.500 humedales, que suponen un $0,22 \%$ de la superficie territorial; estos humedales son en general de pequeño tamaño, pero de primera importancia en cuanto centros de diversidad biológica.

En cuanto al medio marino, los factores oceanográficos y biogeográficos favorecen también que la diversidad biológica de las aguas costeras españolas sea de las mayores de la Unión Europea. Al sur de la Península hacen frontera tres regiones marinas (mauritana, lusitana y mediterránea); de los 49 grandes ecosistemas marinos definidos según el sistema de clasificación global del ambiente marino costero, tres incluyen a las aguas españolas: Costas Ibéricas, Mediterráneo y Corriente de Canarias.

La gran diversidad de hábitats en España alberga una elevada diversidad de especies animales, lo que hace que España sea el país responsable de la conservación de la mayor diversidad faunística de Europa occidental. Se estiman en torno a 80.00090.000 especies de flora y fauna en España, si bien se trata de una cifra conservadora ya que para algunos grupos (especialmente Artrópodos) el conocimiento es muy escaso. Este número se ha incrementado fuertemente pues a mediados de los 90 (Estrategia para la conservación de la BD española, 1994-1999) la cifra de trabajo era de 55.000-60.000 especies animales en España.

El territorio español cuenta con 10.000 especies de plantas diferentes, se calcula que existen unas 20.000 especies de hongos, líquenes y musgos y entre 8.000 y 9.000 especies de plantas vasculares (helechos y plantas con flores) que representan el $80 \%$ de las existentes en la Unión Europea y casi el 60\% de las que se hallan en todo el continente. De este último grupo, más de 6.500 son plantas autóctonas, con unos 1.500 endemismos únicos en el mundo, y otros 500 son endemismos compartidos con el Norte de África.

La estimación actual del número de especies de los vertebrados españoles (ver tabla) ronda las 1.730 especies, correspondientes a 69 peces continentales, 35 anfi- 
bios, 87 reptiles, 158 mamíferos y 521 aves (incluyendo aves reproductoras e invernantes). Esto supone menos del $2 \%$ del número de especies de la fauna española. El resto son invertebrados, fundamentalmente insectos. Sobre este pequeño porcentaje de especies se concentran mayoritariamente los esfuerzos y el dinero dedicado a conservación por administraciones, fundaciones, científicos, ONGs, etc. Dada la amplísima BD española, lo lógico es trabajar en la conservación de los hábitats prioritarios según la Directiva y trabajar especialmente en los taxones amenazados, especialmente los endémicos, así como los taxones emblemáticos o "bandera" (lince ibérico, oso, por mencionar algunos) que puedan servir como cobertura al resto de especies de su comunidad.

El grado de conocimiento puede considerarse bueno para los vertebrados, a pesar de los cambios constantes motivados por estudios más profundos y fundamentalmente por la aplicación de las técnicas genéticas moleculares para la diferenciación de nuevas especies. El listado de especies de los territorios norteafricanos presenta muchas lagunas y debería trabajarse más. Hay un grupo que, curiosamente dada su importancia comercial, no suele mencionarse en los inventarios o estadísticas de la BD española. Son los peces marinos, de los que no sabemos con exactitud el número de especies en nuestras costas, barajándose entre 600 y 1100. Por supuesto, no existen tampoco datos generales sobre el estado de conservación o libros rojos de los peces marinos españoles (con excepción de las especies que se hallan también en los ríos como lampreas, anguilas, esturiones, salmones, etc.). El estudio de los peces marinos españoles es prioritario para completar esta laguna tan Ilamativa.

En el contexto europeo, este patrimonio biológico cobra especial relevancia. Al menos un 54\% del número total de especies conocidas en Europa está en España y cerca del 50\% de especies endémicas de Europa están presentes en nuestro país, siendo muchas de esas especies también exclusivas (endémicas) del territorio español. La siguiente tabla muestra el conocimiento actual (año 2008) de la BD española.

TABLA 7

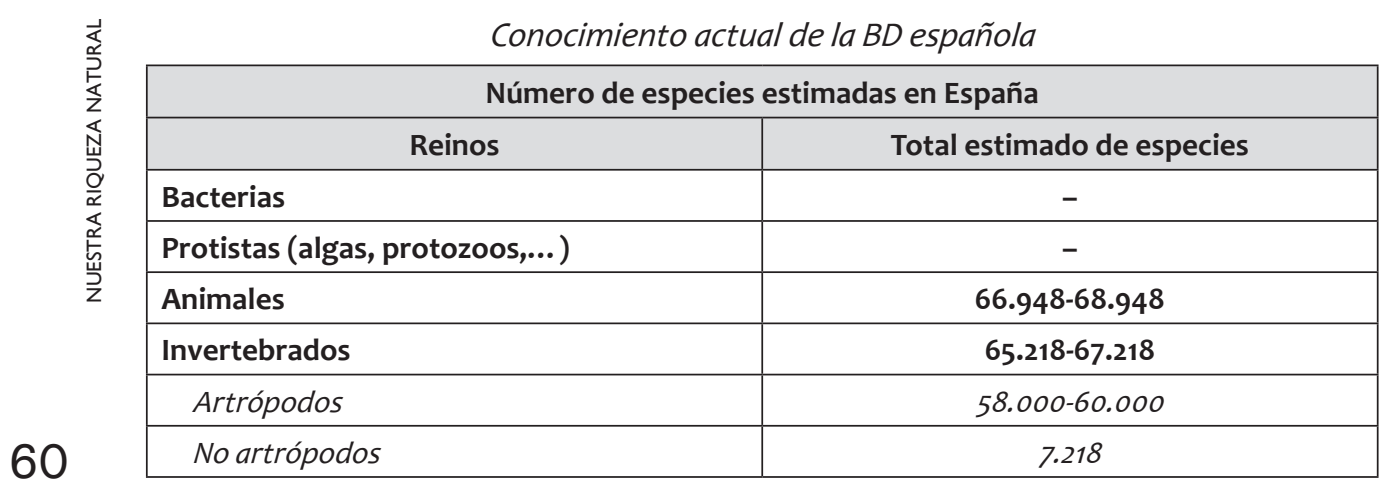


TABLA 7 (cont.)

Conocimiento actual de la BD española

\begin{tabular}{|l|c|}
\hline \multicolumn{2}{|c|}{ Número de especies estimadas en España } \\
\hline Vertebrados & Total estimado de especies \\
\hline Mamíferos & 1.730 \\
\hline Aves & 158 \\
\hline Reptiles & $521^{*}$ \\
\hline Anfibios & 87 \\
\hline Peces Continentales & 35 \\
\hline Peces Marinos & 69 \\
\hline Hongos & $600-1.000$ \\
\hline Plantas & $\mathbf{2 0 . 7 9 0}$ \\
\hline
\end{tabular}

Elaboración Ministerio de Medio Ambiente, 2005 y varias fuentes.

* Esta cifra incluye aves reproductoras, así como migradoras e invernantes que no se reproducen en España. Fuente: de Cuarto informe sobre la diversidad española, 2009.

La importancia de la fauna española, además de por su número de especies, viene dada también por su endemicidad (número de especies restringidas exclusivamente al territorio español); en este sentido, España ocupa un lugar muy importante en el contexto europeo.

Hay que señalar también la importancia de la península Ibérica, Ceuta y los dos archipiélagos para las migraciones de una enorme cantidad de animales. Son muchas las especies, sobre todo de aves, pero también de peces y mamíferos marinos, que utilizan nuestro territorio como lugar de paso entre sus áreas de cría norteñas y sus zonas de invernada tanto mediterráneas como del sur del Sahara, o entre sus lugares de reproducción en el Mediterráneo y de reposo en el Atlántico.

En términos generales, las regiones con mayor grado de endemicidad corresponden a las zonas montañosas y a las áreas insulares, donde el factor aislamiento se ha hecho sentir en los procesos evolutivos de manera extraordinaria. Canarias es un paradigma en cuanto a la riqueza y endemicidad de su flora y fauna. Así, en estas islas, se ha venido describiendo una especie nueva cada seis días en la década 19901999, lo que supone un dato récord en Europa. En la siguiente tabla se muestran los porcentajes de endemicidad estimados para algunos grupos de la biodiversidad en España. 
TABLA 8

Porcentajes de endemicidad para algunos elementos de la biodiversidad española

\begin{tabular}{|l|c|}
\hline \multicolumn{1}{|c|}{ Grupo } & \% endemicidad \\
\hline Plantas Vasculares & $\begin{array}{c}\text { Península y Baleares 18\% } \\
\text { Canarias 30\% }\end{array}$ \\
\hline Monocotiledóneas & $18 \%$ \\
\hline Dicotiledóneas & $30 \%$ \\
\hline Lepidópteros & $7 \%$ \\
\hline Mamíferos terrestres & $13,2 \%$ \\
\hline Aves (nidificantes) & $2,6 \%$ \\
\hline Reptiles & $11,5 \%$ \\
\hline Anfibios & $32 \%$ \\
\hline Peces continentales & $50-55 \% *$ \\
\hline
\end{tabular}

Elaboración Ministerio de Medio Ambiente, 2005 y varias fuentes.

* Esta cifra podría ser más elevada tras la reciente descripción de nuevas especies.

Tomado de Cuarto informe sobre la diversidad española, 2009. Síntesis de los Libros o Listas Rojas y de los Atlas desarrollados o en marcha para el conocimiento de la distribución y del estado de conservación de la biodiversidad española a nivel estatal, con indicación de las fechas de publicación.

\section{El estado de conservación de los vertebrados españoles}

El conocimiento acerca de la distribución y el estado de conservación de la flora y fauna silvestre en España ha avanzando notablemente en la última década. Se sabe que aproximadamente el $31 \%$ de los taxones de vertebrados españoles se encuentran amenazados actualmente, mientras que en materia de conocimiento sobre los invertebrados, todavía queda un largo camino por recorrer. La superficie protegida en España ha crecido notablemente, bien como espacios naturales protegidos por las Comunidades Autónomas, cuya superficie ya abarca el 9,22\% de la superficie española, o bien bajo la Red Natura 2000, en cuyo caso esta superficie se eleva al 26,43\%.

Respecto a las normativas nacionales para la conservación de espacios y taxones, debemos destacar la nueva Ley 42/2007 de conservación del patrimonio natural y la biodiversidad. La Ley 42/2007 establece el "Listado de Especies en Régimen de Protección Especial”, en el que se incluyen 815 especies que deben ser objeto de un seguimiento regular. También se adapta el existente Catálogo Español de Especies Amenazadas (en adelante, CNEA), en el que ahora sólo existen dos categorías de amenaza: en peligro de extinción, con 158 especies, y vulnerable, con 113 especies. Para las especies en peligro, las comunidades autónomas deberán elaborar planes de recuperación en un plazo no superior a 3 años, y para las vulnerables planes de con-

62 servación en un plazo de 5 años. 
En el Catálogo se incluyen los taxones (especies, subespecies y poblaciones) en peligro de extinción y vulnerables. EI CNEA es un registro administrativo abierto con efectos jurídicos claros tanto en las Comunidades Autónomas, como en la Administración Central. Se reconoce para las primeras la posibilidad de elaborar sus catálogos autonómicos y añadir además otras categorías específicas. La última actualización del CNEA es de Octubre de 2007 (ver web del Ministerio de Medio ambiente, Medio Rural y Marino). En el actual CNEA, la mayoría de los taxones corresponden a aves (47\%), seguidos de plantas (22\%). Los peces y anfibios suponen tan solo el $2 \%$ y el $4 \%$ respectivamente. El mayor problema del CNEA está en la falta de actualización rápida con respecto al conocimiento científico y técnico del estado de conservación de los taxones, mejor recogido por las categorías UICN.

En las siguientes figuras se recoge el número de especies amenazadas en el CNEA y las categorías UICN en el año 2005.

\section{FIGURA 3}

Porcentaje de especies amenazadas según a) CNEA (2004) y b) libros Rojos

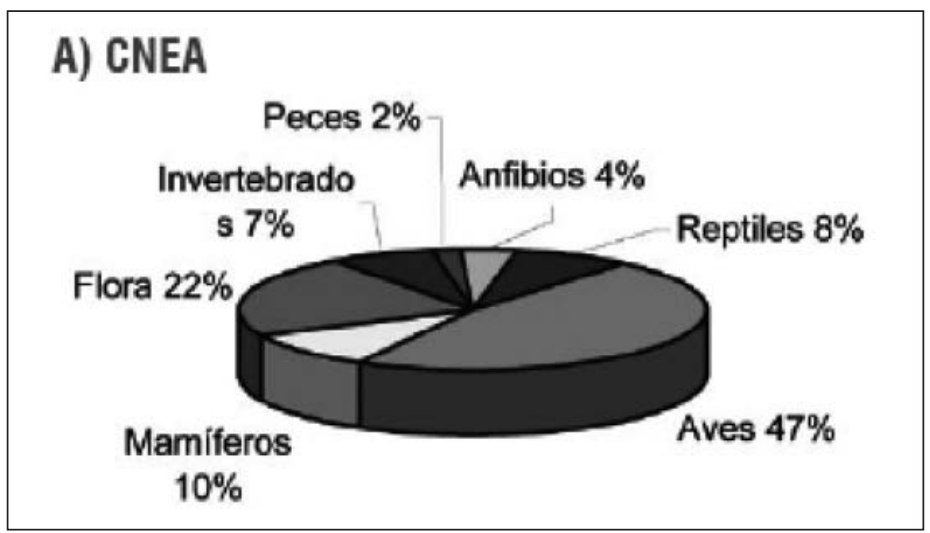

\section{B) LIBROS ROJOS}

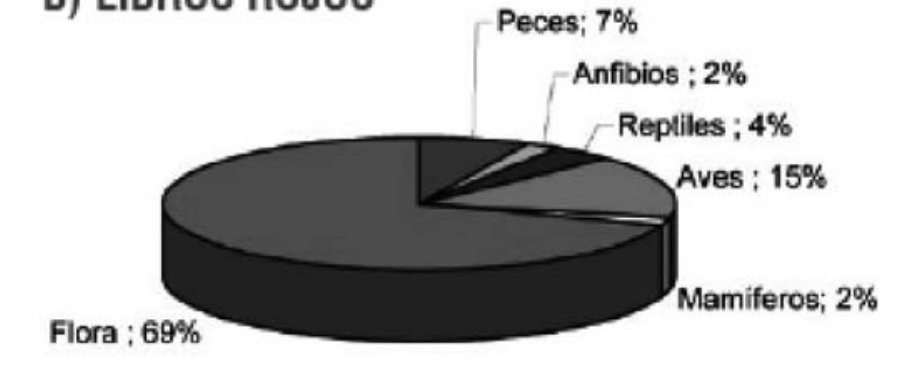

Fuente: Elaboración propia a partir de los datos del perfil ambiental 2005 (MMA). 
Según la nueva Ley 42/2007, se deben elaborar Estrategias nacionales de Conservación para todas las especies en peligro de extinción presentes en más de una Comunidad Autónoma. Hasta 2008 se han aprobado 14 y una Estrategia Nacional de Control de una especie exótica invasora, el mejillón cebra. Más de 105 Planes de Acción (planes de recuperación, conservación, etc.) de especies han sido adoptados por diversos gobiernos autonómicos. A pesar de que el número de Estrategias de Conservación sigue aumentando, quedan todavía muchas por desarrollar. Los estudios sobre las poblaciones de lince ibérico, oso pardo y urogallo cantábrico muestran tendencias preocupantes, mientras que el águila imperial, el buitre negro y el lobo se encuentran en mejor situación, especialmente este último.

\section{TABLA 9}

Estrategias nacionales para la conservación de taxones amenazados aprobadas

\begin{tabular}{|c|c|}
\hline Estrategia Nacional & Fecha de aprobación \\
\hline Lince ibérico & 1999,2008 \\
\hline Oso pardo cantábrico & 1999 \\
\hline Quebrantahuesos & 2000 \\
\hline Águila Imperial Ibérica & 2001 \\
\hline Urogallo cantábrico & 2004 \\
\hline Quebrantahuesos & 2000 \\
\hline Águila imperial & 2001 \\
\hline Urogallo cantábrico & 2004 \\
\hline Lobo & 2005 \\
\hline Malvasía cabeciblanca & 2005 \\
\hline Urogallo pirenaico & 2005 \\
\hline Visón europeo & 2005 \\
\hline Pardela balear & 2005 \\
\hline Oso pardo pirenaico & 2006 \\
\hline Focha moruna & 2007 \\
\hline Margaritota & 2007 \\
\hline Lapa ferruginea & 2008 \\
\hline
\end{tabular}

64 Fuente: Cuarto Informe de la BD española, 2009. 
Las Listas Rojas o Libros Rojos constituyen un inventario científico del estado de conservación de la diversidad biológica animal o vegetal de un territorio, pero carecen de carácter legal, que es, sin embargo, aportado por el CNEA. Se basan en las categorías desarrolladas por la UICN (última versión 2006); que reflejan el grado de amenaza de cada taxón. Su función principal es ser una herramienta orientativa a la hora de crear o modificar un Catálogo de Especies Amenazadas y desempeñan un papel divulgativo y de apoyo a la gestión del medio natural. En los Libros Rojos para España, la mayor proporción de especies amenazadas corresponde a plantas (69\%), seguidas de aves (15\%) y peces (7\%). Existe por tanto una notable discrepancia entre ambos catálogos y libros rojos, principalmente en lo que se refiere a plantas y peces, con porcentajes mucho menores en el CNEA con respecto a los Libros Rojos. Con respecto a la fauna, existen libros rojos de diversos grupos de Artrópodos y actualmente de todos los grupos de vertebrados, con excepción de los peces marinos. En la siguiente tabla podemos ver su evolución histórica.

TABLA 10

\begin{tabular}{|l|c|c|}
\hline \multicolumn{1}{c|}{$\begin{array}{c}\text { Componente de } \\
\text { Biodiversidad }\end{array}$} & Libro Rojo / Lista Roja & Atlas \\
\hline Mamíferos & 2001,2007 & 2001,2007 \\
\hline Aves & 2005 & 2003 \\
\hline Anfibios & 2002 & 2002 \\
\hline Reptiles & 2002 & 2001 \\
\hline Peces & 2006,2009 & 2009 \\
\hline Invertebrados & 2000,2008 & $2004,2006,2008$ \\
\hline Plantas Vasculares & - & 2003 \\
\hline Tipos de hábitats & En proceso & En proceso \\
\hline Briófitos & & 2002 \\
\hline
\end{tabular}

Respecto a la fauna y, concretamente, a las categorías más actualizadas de la UICN (Cuarto Informe sobre biodiversidad española, 2009), los vertebrados, para los que se tiene más información, puede decirse que aproximadamente un 30\% de las especies o subespecies españolas están dentro de las categorías "En Peligro Crítico", "En Peligro" y "Vulnerable": 30\% de los anfibios, 23\% de los reptiles, 49\% de los peces continentales, $19 \%$ de los mamíferos y $33 \%$ de las aves reproductoras. Es especialmente preocupante el estado de la ictiofauna continental española, principalmente por tratarse del grupo con el mayor porcentaje de endemismos. 
FIGURA 4

Estado de conservación de los vertebrados en España (Fuente: Ministerio de Medio Ambiente y Medio Rural y Marino, a partir de Libros y Listas Rojas. 2009)
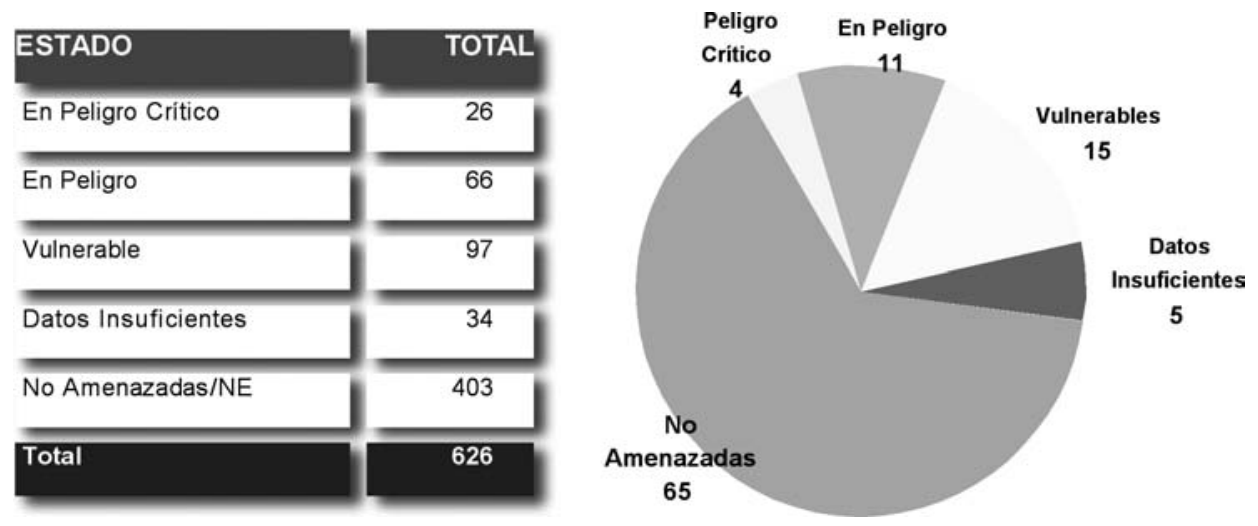

La aplicación de las nuevas categorías UICN y el mayor conocimiento sobre el estado de conservación de la fauna explica parte del aumento en el número de especies incluidas en alguna categoría de amenaza. No obstante, parece claro que el estado de conservación de la fauna de vertebrados terrestres españoles, considerados en conjunto, no sólo no ha mejorado durante el periodo 1992-2008, sino que parece haber empeorado ligeramente. Se espera un avance significativo en el conocimiento de la distribución y el estado de conservación de la biodiversidad en España, dentro del desarrollo reglamentario de la nueva Ley 42/2007, del Patrimonio Natural y de la Biodiversidad, pues en ella se impulsa la creación del Inventario Español del Patrimonio Natural y de la Biodiversidad.

\section{LOS PECES CONTINENTALES ESPAÑOLES}

Los peces son uno de los grupos más diversos de los vertebrados, quizá después de los mamíferos, no sólo en sus formas o tamaños, sino también en su biología y ecología. En cuanto al número de especies descritos, más de la mitad de los vertebrados vivientes son peces óseos del grupo de los teleósteos (51,1\%; 24.618 peces frente a 23.550 tetrápodos (anfibios, reptiles, aves y mamíferos). Nelson (1994) estimó en casi 10.000 el número de especies (40,5\% de los peces) que habitan las aguas continentales o dulces, ambientes que únicamente ocupan el $1 \%$ de la superficie terrestre y conforman menos del 0,01\% del agua presente en el planeta.

El conocimiento de los peces continentales (también llamados epicontinentales, fluviales o dulceacuícolas) españoles, que incluyen a los de agua dulce y estuarios, y deja fuera a las especies marinas, ha avanzado mucho en las dos últimas décadas en 66 España. Por un lado el descubrimiento de numerosas nuevas especies, muchas endé- 
micas de cada cuenca, y los estudios en profundidad de la filogenia de los grupos, ha llevado a grandes cambios taxonómicos, a nivel de género y especie, lo que hace difícil reconocer los nombres científicos actuales de las especies comunes.

Varios trabajos son fundamentales a escala estatal: el Atlas y Libro rojo de los peces continentales españoles (Doadrio, 2002) y otros excelentes trabajos resumen (Doadrio \& Elvira, 2002; Granado Lorencio, 2002). Numerosos trabajos analizan también la biogeografía, el estado de conservación, las especies exóticas introducidas, etc. (ver bibliografía).

Los peces tratados aquí incluyen las especies ibéricas y las de Baleares, pero no las Islas Canarias, pues no tiene ninguna especie fluvial dado su origen volcánico. En realidad, hablar de peces españoles es prácticamente hablar del territorio de la Península Ibérica. De acuerdo al Atlas (Doadrio, 2002), en la Península Ibérica existen 69 especies, entre autóctonas y exóticas, más diversos taxones a nivel subespecífico. En 1986 sólo se citaban 56 especies, lo que indica el rápido crecimiento en el conocimiento. De éstas, 35 son autóctonas de agua dulce; 10, también autóctonas, son de hábitos estuarinos y/o migradores; y 24 son especies exóticas, introducidas o foráneas, de agua dulce.

Hace años, se consideraba a la ictiofauna fluvial española como pobre en especies, comparada con la centroeuropea (Elvira, 1997). El gran número de especies endémicas descritas por técnicas morfológicas y/o moleculares hace que actualmente se la considere, por el contrario, como una de las más ricas y diversas de Europa, comparable a la de Grecia, pero con la importante característica de tener una muy elevada proporción de especies endémicas, más del 80\% de las autóctonas, especialmente en el grupo de los Cipriniformes y Ciprinodontiformes (Doadrio, 2002). El elevado número de especies endémicas se debe probablemente a la antigüedad de su origen, 25 millones de años, y al aislamiento posterior de la Península ibérica con relación a las faunas europeas y africanas (Elvira y Almodóvar, 2001). La situación actual es la existencia de una ictiofauna antigua, rica y diversa, que ha sufrido varios procesos de aislamiento, el último de los cuales ocurrió hace aproximadamente dos millones de años.

El origen de la ictiofauna continental española es antiguo y se remonta al Oligoceno Superior, hace al menos 25 millones de años. Fue en esa época cuando aparecieron los primeros Ciprínidos y comenzaron a desaparecer las familias tropicales que predominaban anteriormente de la península Ibérica (Doadrio \& Elvira, 2002). La colonización de la Península, hace 25 millones de años, por esta fauna moderna de peces continentales parece haber ocurrido por el norte, antes de que se levantaran de forma definitiva los Pirineos y la Península quedara aislada del resto de Europa y del norte de África. Sólo en el Mioceno Superior, con la desecación del Mediterráneo, pudo ser otra vez colonizada por fauna africana o centroeuropea. Por ejemplo, durante la regresión del Mediterráneo fue posible la unión de los ríos del sureste de Francia y de Cataluña, con el consiguiente intercambio de peces. Lo mismo pudo ocu- 
rrir con la unión de los ríos del sur de España y del Rif norteafricano. Sin embargo, desde la apertura del estrecho de Gibraltar, hace 5,5 millones de años, la Península ha quedado prácticamente aislada de la influencia de otras faunas de peces.

La configuración de la Península a través del tiempo debió de ser responsable de que sólo unos pequeños grupos de peces la colonizaran, evolucionando aisladamente y convirtiéndose en un laboratorio biológico para estudiar interesantes fenómenos de especiación. Por otro lado se encuentran taxones hibridogenéticos de peces, constituidos por hembras poliploides, asociados habitualmente a medios acuáticos muy temporales como son los ríos mediterráneos o los del desierto de México.

Otra característica es la pequeña distribución de muchos de los endemismos, con áreas de distribución restringidas a una parte de una cuenca, a una sola cuenca o a unas pocas cuencas fluviales. Ello se debe a la formación de las cuencas peninsulares al final del Plioceno, hace unos dos millones de años.

Repasaremos las principales especies de peces, en un orden evolutivo y teniendo en cuenta si son endémicas y/o están amenazadas. La familia de las lampreas, los Petromizóntidos (vertebrados agnados que no son verdaderos peces), está representada en España por 3 especies, de las cuales la lamprea de arroyo (Lampetra planari) es exclusivamente fluvial y se halla muy amenazada, con una sola población en ríos de Navarra. La lamprea de río (Lampetra fluviatilis) y la lamprea marina (Petromyzon marinus) son migradores anadromos (que viven en el mar pero se reproducen en los ríos). La lamprea de río se considera extinguida en España, aunque antes ocupaba la cuenca del Tajo. La lamprea marina ocupa los ríos cantábricos y las zonas de la desembocadura de diversos ríos del suroeste peninsular y el Ebro.

El esturión (Acipenser sturio) es el único representante autóctono en España de los Acipenséridos, una familia de peces óseos primitivos, los Condrósteos. En España hay citas históricas de esturión en numerosos ríos (en Sevilla había una fábrica de caviar, las huevas del esturión), pero actualmente sólo hay datos ya no tan recientes (año 1992) en la desembocadura del Guadalquivir. Es una especie en peligro crítico de extinción en España. Otra especie, el esturión del Adriático, parece ser una especie introducida, aunque ha habido una fuerte controversia al respecto.

La anguila (Anguilla anguilla), perteneciente a la familia Anguílidos, es una especie catadroma, ya que que habita los ríos de Europa occidental antes de alcanzar la madurez sexual pero migra para reproducirse en el océano Atlántico, en el mar de los Sargazos, y retorna como larva leptocéfala y angula a las costas y ríos de Europa occidental. En España se distribuye por todas las cuencas hidrográficas, aunque la construcción de las grandes presas ha limitado o impedido la posibilidad de completar su migración.

Dentro de los Salmónidos autóctonos, debemos destacar dos peces original68 mente anadromos (que viven en el mar y remontan los ríos para reproducirse). El 
salmón (Salmo salar) y la trucha común o pintona (Salmo trutta), en la que algunas poblaciones costeras remontan los ríos desde el mar para desovar (los reos) y parte de la población reside permanentemente en agua dulce, la trucha común o fario. El salmón habita los ríos del norte peninsular, del Miño al Bidasoa. Las truchas reos viven en las zonas costeras del norte mientras que las poblaciones residentes en agua dulce se encuentran en aguas frías, limpias y bien oxigenadas, en las zonas medias y altas de los ríos peninsulares. No está presente en la cuenca del Guadiana y algunos ríos de Levante y del sur peninsular

La aplicación masiva de las técnicas moleculares ha tenido como consecuencia la descripción de nuevos géneros y especies. Sólo en la familia de los Ciprínidos se han descrito 10 nuevas especies de endemismos ibéricos desde 2003. Cuatro son exclusivamente portugueses, mientras que el resto son endemismos españoles, como la Pardilla del Jándula Iberochondrostoma oretanum, el Bagre Squalius laietanus, el Cacho del Gallo Squalius castellanus, el Cacho del Guadiaro Squalius malacitanus y el Cacho de Levante Squalius valentinus (ver más información en Doadrio, 2002 y Elvira \& Almodóvar, 2008).

Los Ciprínidos constituyen la familia más diversificada y representativa de la ictiofauna dulceacuícola. En España se encuentran especies de siete géneros, cuatro de los cuales (Anaecypris, Barbus, Chondrostoma y Squalius) incluyen un elevado número de especies endémicas. Destacaremos al jarabugo (Anaecypris hispanica) por ser un endemismo ibérico de distribución muy limitada, pues sólo se encuentra en la cuenca del Guadiana y quizá en la del Guadalquivir. El género Barbus es uno de los más diversificados de la península Ibérica, con al menos ocho especies: el barbo común (Barbus bocagei), barbo comizo (B.comizo), barbo de Graells (B.graellsii), barbo mediterráneo (B.guiraonis), barbo colirrojo (B.haasi), barbo de montaña (B. meridionalis), barbo cabecicorto (B.microcephalus) y barbo gitano (B. sclateri).

El género Chondrostoma está representado en España por 9 especies. De las 6 más grandes en tamaño, 3 habitan el centro y oeste peninsular, y las otras 3 están limitadas al cuadrante nororiental. Las primeras son la boga del Duero (Ch.duriense), que ocupa las cuencas comprendidas entre el Eo y el Duero; la boga de la cuenca del Tajo (Ch. polylepys), y la boga del Guadiana (Ch. willkommii). Los grandes Chondrostoma no presentan poblaciones diferenciadas por cuencas fluviales, debido a su capacidad de dispersión y a sus migraciones en la época de la reproducción, como también en los barbos. Las dos especies de menor tamaño son la bermejuela (Ch.arcasii) y la pardilla (Ch.lemmingii). La bermejuela vive en el centro y norte peninsular. La pardilla se distribuye por el suroeste de la Península. Las especies pequeñas de Chondrostoma muestran unas poblaciones muy diferenciadas, que no concuerdan estrictamente con las cuencas fluviales ibéricas. Como ejemplo, Doadrio \& Elvira (2007) han descrito la que hasta ahora es la última especie de pez fluvial español, la sarda (Achondrostoma salmantinum), que sólo vive en una pequeña área de la provincia de Salamanca, en la Cuenca del Duero. La nueva especie está considerada "en peligro" debido a su restringida distribución así como a amenazas como la progresiva reducción de su há- 
bitat debida a la extracción excesiva de agua para la agricultura extensiva y la construcción de diques y presas en los cursos fluviales.

Dentro del género Squalius se reconocen en España dos líneas genéticas. La primera representada por el bagre (Squalius cephalus) que vive en la cuenca del Ebro y en las cuencas internas de Cataluña, así como al norte de los Pirineos. La otra línea está integrada por 4 especies endémicas de la península Ibérica: (S. alburnoides), el bordallo (S. caroliterti), la bogardilla (S. palaciosi) y el cacho (S.pyrenaicus). El calandino se distribuye por las cuencas de los Tajo, Guadiana, Odiel y Guadalquivir, y presenta una reproducción unisexual de tipo hibridogenético. El bordallo y el cacho son especies con reproducción sexual. El primero se distribuye por diversas cuencas del Oeste peninsular. El cacho se encuentra en la zona meridional de la Península (Tajo y tramo final del Ebro hacia el Sur). La bogardilla vive sólo se ha citado en una pequeña parte de la cuenca del Guadalquivir.

La familia de los Cobítidos está representada por tres especies endémicas de la Península: la lamprehuela (Cobitis calderoni), la colmilleja (C. paludica) y la colmilleja del Alagón (C.vettonica). La lamprehuela vive en el norte peninsular, en las cuencas del Duero y del Ebro, y más localmente en el Tajo. La colmilleja se distribuye por el centro y sur de la Península. La colmilleja del Alagón es una especie exclusiva de la subcuenca del Alagón, afluente del río Tajo.

La familia de los Balitóridos está representado por una especie, el lobo de río (Barbatula barbatula), de amplia distribución en Eurasia central y septentrional y que en España ocupa la zona comprendida entre los ríos Bidasoa y Nervión, en la vertiente cantábrica, y en la cuenca del Ebro.

Los Ciprinodóntidos y Valéncidos son dos familias próximas de Cprinodontiformes que presentan dos especies endémicas en España, el fartet (Aphanius iberus) y el samaruc (Valencia hispanica), ambas con una distribución mínima debida en gran parte a la destrucción de su hábitat típico, albuferas, aguas costeras, marjales, lagunas y charlcas de poca profundidad. El género Aphanius tiene una distribución circunmediterránea, mientras que el género Valencia tiene sólo dos especies, el samaruc del Mediterráneo español y Valencia letoumeouxi, de Grecia. Aphanius muestra dos poblaciones bien diferenciadas, una atlántica y otra mediterránea, que para algunos son especies diferentes. La población mediterránea se extiende por aguas próximas a la costa, desde los aiguamolls del aito Ampurdán hasta la albufera de Adra; mientras que la atlántica ocupa desde Cádiz hasta las marismas del Guadalquivir. El samaruc presenta un área de distribución muy restringida, entre el delta del Ebro y el marjal de Pego-Oliva, con sólo 6 o 7 localidades con poblaciones estables. Se trata de uno de los peces fluviales más amenazados.

Las familias de los Gasterosteidos, Cótidos y Blénidos incluyen en España especies exclusivamente fluviales. Los Gasterosteidos al espinoso (Gasterosteus gym70 nurus), en aguas próximas al litoral cantábrico y mediterráneo, y con una amplia dis- 
tribución en las aguas dulces de Galicia. El único representante de los Cótidos es el cavilat (Cottus gobio) que vive en los cursos altos de varios ríos pirenaicos. En cuanto a los Blénidos, el fraile (Salaria fluviatilis) es su única especie fluvial en España, con poblaciones a lo largo del Mediterráneo y en algunos puntos de la cuenca del Guadiana y del sur de España.

\section{Los peces exóticos introducidos}

Desgraciadamente, el número de especies de peces exóticas sigue creciendo en los ríos españoles, y su aclimatación (adaptación y reproducción en el medio natural) es uno de los principales factores de amenaza para los peces autóctonos. Los peces exóticos depredan, compiten o incluso hibridan con las especies autóctonas, de forma que las comunidades de peces actuales tienen muy poco que ver con las de hace 30 o 40 años y en general las especies autóctonas de pequeño tamaño y endémicas están ahora muy amenazadas. Al menos 24 especies de peces se han aclimatado en los medios fluviales españoles (Elvira, 1997; Elvira \& Almodóvar, 2001; Doadrio, 2002; Doadrio \& Elvira, 2002). Al principio se introdujeron para su consumo, pesca deportiva, acuariofilia, etc. Aunque en 1935 eran sólo 6 las especies introducidas, su número se incrementó exponencialmente en la segunda mitad del siglo XX. Las últimas introducciones realizadas "oficialmente" por la administración española fueron las del lucio en 1949, el blackbass en 1955 y el hucho o salmón del Danubio en 1968. Desde entonces, las nuevas especies han sido liberadas por particulares para su pesca o liberaciones desde la acuariofilia o la acuicultura. Entre las más graves está la de los siluros del Ebro en los 80, pero desde la década de 1990 se han liberado el alburno, esturión siberiano, brema blanca, pez gato moteado, fartet, gupi, etc.

Los peces exóticos tienen actualmente una amplia dispersión en las diferentes cuencas hidrográficas. La proporción de peces nativos frente a exóticos varía en las grandes cuencas peninsulares entre el 71\% del total de especies en Galicia (la región menos alterada) y el $41 \%$ en la cuenca del Duero, la más modificada. La media nacional es del 63\%. Un problema importante es la introducción de peces autóctonos ibéricos en cuencas donde no estaban naturalmente, generalmente debido a los trasvases entre cuencas. Esto es fácil dado el alto nivel de endemicidad en las cuencas hidrográficas ibéricas. Entres las especies “trasvasadas" podemos citar al carpín, el lobo de río, la colmilleja y la madrilla.

La vulnerabilidad de los sistemas acuáticos se maximiza, si cabe, en áreas geográficas de clima mediterráneo, con medios acuáticos temporales. A escala mundial, entre el $60 \%$ y el $80 \%$ de los peces nativos continentales de estas regiones están en grave peligro de extinción. El 56\% de los peces nativos del área mediterránea se halla amenazado (18\% CR: En Peligro Crítico; 18\% EN: En Peligro; 20\% VU: Vulnerable). La situación de grave declive de los peces autóctonos en la Península Ibérica es evidente. Este aspecto ha sido destacado en la Declaración de Peñíscola sobre la conservación de los peces continentales y sus hábitats (1994), y en el Primer 
seminario sobre conservación, recuperación y gestión de la ictiofauna continental ibérica (1997).

En el Atlas y Libro rojo (Doadrio 2002) se recogen 46 especies de peces autóctonos. Según las categorías UICN, el $84,7 \%$ presentan un nivel de amenaza superior al vulnerable. Los dos factores de amenaza más importantes son la destrucción y deterioro de los hábitats acuáticos y la introducción de especies exóticas.

El clima de la Península es, en general, mediterráneo, excepto en la vertiente cantábrica, con aparición de lluvias torrenciales y sequías que se suceden de forma más o menos impredecible. Como consecuencia, la proliferación de embalses desde mediados del siglo XIX, conduce en tener en la actualidad más de mil grandes embalses. La consecuencia inmediata y directa es el bloqueo de las migraciones aguas hacia y desde el mar, y por tanto, su capacidad reproductiva, encontrándose sin excepción amenazadas, cuando no en grave peligro de extinción.

La degradación directa y la contaminación de los hábitat acuáticos, tanto fluviales, como lagunas temporales o permanentes es una amenaza directa. Por un lado, la contaminación desmedida producto de los vertidos sistemáticos provenientes de industrias y ciudades. Por otro, la tecnificación de la agricultura y la consiguiente utilización de herbicidas, abonos no naturales, fertilizantes, etc. y un largo etcétera de sales y nutrientes de cualquier tipo que van a parar a los medios acuáticos y ríos.

Otro factor de riesgo para los intercambios de fauna son las conexiones artificiales entre grandes cuencas. Aunque en España se carece de grandes conexiones entre cuencas, la única de importancia, el trasvase Tajo-Segura, aparece ya como responsable de la llegada del pez rojo o carpín, del gobio y la boga del Tajo a la cuenca del Segura; de la boga del Tajo y del calandino a la cuenca del Júcar y de la bermejuela a la del Guadiana. Por último, debemos recalcar la sobrepesca deportiva como un factor de amenaza. Por otro lado, la repoblación con especies y líneas genéticas no autótoctonas, por ejemplo en las truchas.

\section{LA HERPETOFAUNA ESPAÑOLA}

Los anfibios y reptiles suelen considerarse conjuntamente, llamándolos herpetos o herpetofauna, y a la parte de la zoología que los estudia se la conoce como "herpetología". El agruparlos no se debe a ninguna razón científica especial, salvo la tradición, debido a que son vertebrados ectotermos terrestres, frente a los endodermos (aves y mamíferos), y al no tener un número tan elevado de especies como el de aves o mamíferos, lo que suele agruparlos en los libros y guías de campo. Comparten también algunos métodos de muestreo de campo comunes. Son también muy sensibles a las alteraciones ambientales. Los anfibios son en general buenos bioindicadores debido a su piel permeable a los agentes químicos, ciclos biológicos que combi-

72 nan fases terrestres y acuáticas y a habitar tanto el medio acuático, al menos como 
larvas, y el terrestre. Anfibios y reptiles están estrechamente ligados a sus hábitats y biotopos de reproducción debido a su escasa movilidad, lo que les hace especialmente sensibles a cambios locales concretos que impliquen la alteración, contaminación o destrucción de sus hábitats.

La herpetología española ha crecido exponencialmente; por un lado el conocimiento de la distribución y biología de las especies desde la década de los 80 debido al incremento en el número de herpetólogos aficionados o "profesionales" de las universidades y centros de investigación. También está aumentando el interés de la sociedad y las administraciones nacional y autonómicas por estos grupos de vertebrados, antes olvidados, y de los que se está empezando a comprender su importancia como bioindicadores de la salud de los sistemas ecológicos y su papel fundamental en las redes alimenticias y los ecosistemas.

Para preparar este texto hemos utilizado fundamentalmente las siguientes publicaciones, teniendo en cuenta que el número de publicaciones recientes sobre los herpetos españoles es enorme. Algunas publicaciones históricamente relevantes son la obra “Distribución y biogeografía de los anfibios y reptiles en España" (Pleguezuelos, 1997), realizada colectivamente por miembros de la Asociación Herpetológica Española (AHE), una asociación fundamental en el estudio y conservación de los anfibios y reptiles españoles. El "Atlas y Libro rojo de los anfibios y reptiles españoles" (Pleguezuelos, Márquez \& Lizana, 2002), es otra obra colectiva fundamental de la AHE financiada por el Ministerio de Medio Ambiente. Las recientes guías sobre los herpetos españoles como las de Barbadillo et al. (1999), Salvador \& García París (2001) y Salvador \& Pleguezuelos (2002) son también excelentes. Son también fundamentales las monografías de la serie "Fauna Ibérica" del CSIC-MNCN sobre los reptiles españoles (Salvador, 1998) y sobre los anfibios españoles (García Paris et al, 2004). Como resumen, aunque ligeramente anticuado por la gran cantidad de especies descritas posteriormente, citaremos también el capítulo sobre los anfibios y reptiles españoles de Barbadillo (2002), en el libro La Naturaleza en España (Asensio, 2002). Un buen lugar para conocer las últimas novedades es la página web de la AHE (www.herpetologica.org/www.ahe.org) y la de Vertebrados ibéricos del Museo Nacional de Ciencias Naturales-CSIC.

En el Atlas y Libro rojo de los anfibios y reptiles de España del año 2002 (Pleguezuelos et al., 2002), se recogían 32 especies de anfibios (10 urodelos, 22 anuros) y 76 de reptiles ( 9 quelonios, 51 saurios, 3 anfisbénidos, 13 ofidios), considerando sólo las especies autóctonas o de introducción antigua. Esta diversidad específica es la más elevada entre los países de Europa Occidental, lo cual también implica una elevada responsabilidad española en la conservación de la herpetofauna europea. Esta cifra ha aumentado considerablemente desde el año 2002 por la descripción de nuevas especies.

Para señalar brevemente las características definitorias de la herpetofauna española, deberíamos destacar la riqueza en especies, comparada con otros países euro- 
peos, pero especialmente el número de endemismos, tanto insulares (Baleares y Canarias), como de zonas montañosas o incluso cuencas hidrográficas en el caso de los anfibios. España cuanta en la actualidad con al menos 35 especies de anfibios y 87 de reptiles, es decir 122 "herpetos". El porcentaje de endemismos alcanzaría al menos el $45 \%$ de las especies.

El desarrollo de nuevas técnicas genéticas y moleculares y una mayor inversión científica y económica, han propiciado cambios recientes importantes en la taxonomía de los anfibios y reptiles españoles. Numerosas especies de herpetos se han descrito en los últimos años y la nomenclatura ha cambiado notablemente a nivel genérico. Remitimos a la lista patrón actualizada (AHE, 2009, ver web) para el conocimiento de dichos cambios.

En la última década se han descritos muchos nuevos taxones (especies y subespecies) de anfibios españoles, y se siguen describiendo a un ritmo incluso acelerado. Por ejemplo desde 1993 se han reconocido como especies válidas los anfibios Rana pyrenaica, Alytes dickhillenii, Discoglossus jeanneae, Pelodytes ibericus, Triturus pygmaeus, Calotriton arnoldi, etc. Entre los reptiles se han descrito Lacerta bilineata Podarcis atrata, diversas lagartijas del grupo Iberolacerta (Iberolacerta aurelioi, I..aranica, I. bonnali, I. martinezricai e I. galani). Por otro lado Podarcis carbonelli, Psammodromus manuelae, Psammodromus.jeanneae y otras numerosas novedades que están en marcha, como la separación de Podarcis hispanica en varias especies ibéricas. Comentaremos más adelante las novedades más importantes. El número de subespecies descritas es también muy alto.

Las razones para esta importante riqueza específica se podrían resumir en tres. Primero, la Península Ibérica se encuentra en un lugar biogeográficamente privilegiado, entre Europa y África, sometida a una larga e interesante historia paleogeográfica, con antiguas etapas de aislamiento del continente europeo, posterior conexión a éste, y conexiones y desconexiones con África. Ello ha favorecido el aumento de su biodiversidad, a través de la colonización por parte de fauna europea y africana, y de la aparición de muchos procesos de especiación por aislamiento, que explican la elevada tasa de endemismos para ser, aunque peninsular, un territorio continental.

Segunda, la elevada diversidad de reptiles en las Islas Canarias, que albergan 14 especies, casi todas endémicas, algunas conocidas como fósiles desde hace tiempo, pero con poblaciones supervivientes recientemente descubiertas. $Y$ en tercer lugar, la inclusión plena como fauna española de la presente en los territorios transfretanos que España posee en el Norte de Africa (Ceuta, Melilla, Chafarinas, etc.) que con sus escasos $35 \mathrm{~km}^{2}$ de extensión, aportan a la fauna española al menos 4 especies de anfibios y 10 de reptiles, en la mayoría de los casos especies que solo se encuentran en estos territorios dentro de la entidad administrativa de Europa.

Por otra parte, no podemos olvidar las especies introducidas. La introducción de 74 seres vivos fuera de su área de distribución natural representa, tras la pérdida de há- 
bitat, la segunda causa de amenaza a la biodiversidad global (Primack \& Ros, 2002). La introducción de seres vivos tiene un impacto negativo sobre las especies autóctonas a través de la competencia, depredación, contaminación genética, introducción de patógenos, etc. (Pleguezuelos, 2002). El número de especies de herpetos introducidos en España es creciente y preocupante, en especial en cuanto a las especies que se aclimatan como los galápagos de Florida. El problema es especialmente preocupante en los archipiélagos balear y canario. En Baleares, al menos 13 de los 16 herpetos son introducidas. En las Canarias la relación es de al menos 6 especies introducidas frente a 14 autóctonas. En las Islas Baleares, la rana verde común ha sido responsabilizada de la casi extinción (Alytes muletensis) o disminución de especies nativas.

En la Península Ibérica el número de especies introducidas es de al menos 6 frente a las autóctonas (68). A pesar de la gran cantidad de especies introducidas en Iberia, muchas son de introducción antigua y han afectado poco a la herpetofauna autóctona. En la Península, las regiones sureñas, en especial Andalucía, debido a su clima y extensión, albergan el mayor número de taxones introducidos, especialmente si se considera a los aclimatados. También en las cercanías de las grandes ciudades, como Madrid, Barcelona o Valencia, por citar algunas, se encuentran un buen número de herpetos introducidos.

\section{Los anfibios españoles}

Se considera actualmente la existencia de 35 especies en el territorio español, incluyendo la Península Ibérica, Baleares y Canarias (donde los anfibios existentes son introducidos) y también a los, al menos, 4 anfibios presentes en los territorios españoles nortefricanos. Algunas especies son dudosas como la especie híbrida Rana grafi. Para la nomenclatura seguimos la lista patrón propuesta por la AHE (2009) que presenta numerosos cambios tanto en género como en especies. De las 35 citadas en España, al menos 12 son endemismos ibéricos (35\%) y 5 (11,4\%) son endemismos "españoles", que no se encuentran en Portugal y por tanto España tiene una enorme responsabilidad en su conservación.

Los anfibios españoles pertenecen a 7 familias. El Orden Urodelos (los anfibios con cola en estado adulto) sólo tiene una familia en España, los Salamándridos, que incluyen a las salamandras y los tritones. Son 11 especies; dos de ellas, la salamandra moruna (Salamandra algira) y el gallipato (Pleurodeles walt), en el norte de África. El resto de especies son la salamandra rabilarga (Chioglossa lusitanica), el tritón pirenaico (Calotriton asper), el tritón del Montseny (Calotriton arnoldi), el gallipato (Pleurodeles walt') y la salamandra común (Salamandra salamandra).

Recientemente se han producido varios cambios dentro de los tritones típicos, ya que el género Triturus se ha dividido en 3 géneros diferentes. Triturus incluiría ahora a los tritones de mayor tamaño, el tritón jaspeado ( T. marmoratus) y el tritón pigmeo ( $T$. 
pygmaeus). Lissotriton incluiría al tritón ibérico o de Boscá (Lissotriton boscai) y al tritón palmeado (L. helveticus); y el género Mesotriton al tritón alpino M.alpestris.

Debemos destacar al tritón del Montseny (Calotriton arnoldi), muy próximo al tritón pirenaico (Calotriton asper, antes Euproctus) como el urodelo más recientemente descrito en España. Otras especies podrían describirse en un próximo futuro, relacionadas con el tritón ibérico (L.boscai) y con el gallipato ( $P$. walt)).

Los Anuros (anfibios sin cola en estado adulto) incluyen al menos 24 especies en el territorio español. Siete de ellas en la Península y Baleares y al menos 2 en el Norte de África, Bufo mauritanicus, el sapo moruno y Rana saharica, la rana verde africana. Hay dudas sobre si considerar al sapo partero del norte de África, como una especie separada (Alytes maurus) o seguir considerándola una subespecie de Alytes obstetricans. La mayor parte de los autores se inclinan por considerarlo una especie diferenciada.

Los Discoglósidos reúnen a los Anuros más primitivos de nuestra fauna. Comprenden 8 especies de los géneros Discoglossus y Alytes. El género Discoglossus comprende 4 especies, 3 peninsulares, dos autóctonas y endemismos ibéricos que son el sapillo pintojo ibérico (Discoglossus galganoi) y el sapillo pintojo meridional (Discoglossus jeanneae). El sapillo pintojo mediterráneo (Discoglossus pictus) es una especie introducida desde el Norte de África que habita la zona de Cataluña y Francia y el Norte de África. Para algunos autores, las poblaciones de D.pictus norteafricanas pertenecerían a la especie $D$. scovazzi, en lugar de ser una subespecie ( $D$. pictus scovazzi).

Los sapos parteros españoles (género Alytes) comprenden 4 (para algunos 5) especies. 1 endemismo español, 2 endemismos ibéricos y una especie de distribución europea. Están amenazados en diversos grados, desde la categoría de en peligro de extinción a vulnerable. Son los endemismos ibéricos sapo partero ibérico (Alytes cisternasii) y sapo partero de las Sierras béticas (A.dickhilleni). El sapo partero común (A.obstetricans) tiene una distribución centroeuropea además de ibérica. La especie más destacable de los Anuros por ser un endemismo exclusivamente español y estar en peligro de extinción es el sapo partero de las Baleares o ferreret (Alytes muletensis) que habita actualmente sólo los barrancos de la Sierra de Tramontana.en el Norte de Mallorca.

Los Bufónidos son los sapos terrestres típicos (géneros Bufo y Epidalea) e incluyen al menos 4 especies, 1 en el Norte de África (Bufo mauritanicus). El resto de especies son Bufo bufo, el sapo común y Epidalea calamita (antes Bufo calamita), el sapo corredor. Se ha propuesto que el sapo verde de las Baleares (Bufo viridis balearicus) sea elevado a la categoría de especie, Bufo balearicus.

La familia Hílidos (ranitas de San Antonio) tiene un enorme número de especies 76 en el mundo, pero sólo dos especies en España, la rana de San Antonio (Hyla arborea) 
y la ranita meridional (H. meridionalis). Ésta se halla en la Península y Canarias. Recientemente se comprobó que $H$. meridionalis es una especie introducida desde el Norte de África en tiempos recientes.

La familia de los Pelobátidos o sapos de espuelas sólo tiene una especie en territorio español (Pelobates cultripes). Poseen una espuela córnea es sus patas traseras que les sirve para excavar en suelos arenosos o blandos. Cercana es la familia Pelodytidae, de los sapillos moteados, con 2 especies, el sapillo moteado común (Pelodytes punctatus) y el sapillo moteado ibérico (P. ibericus), un endemismo ibérico descrito en el año 2000.

La familia Ranidae incluye 7 especies, las ranas pardas ( 5 especies) y las verdes (2). Las ranas pardas son la rana ágil (Rana dalmatina), la rana patilarga (Rana iberica, endemismo ibérico), la rana bermeja (Rana temporaria) y la rana del Pirineo, endemismo español (Rana pyrenaica). Las ranas verdes son la rana verde común, Pelophylax perezi (antes Rana perezi), que se halla en la Península e introducida en Baleares y Canarias. La rana verde norteafricana (Rana saharica) se encuentra en el Norte de África.

En la herpetofauna ibérica, destacan por su importancia los elementos endémicos. En el caso de los anfibios, los endemismos (al menos 12 especies) representan más del $40 \%$ del total de las especies autóctonas de España, siendo los Salamándridos y los Discoglósidos las familias que agrupan a un mayor número de ellos, seguidos de los Ránidos, con 2, y de los Pelodítidos, con al menos una.

Los patrones de distribución exhibidos por los endemismos ibéricos permiten realizar diferentes grupos. Un grupo de anfibios habita la mitad occidental ibérica y los sistemas montañosos del centro y sur Ibérico. Son el tritón ibérico (Lissotriton boscai), la rana patilarga (Rana iberica) o el sapillo pintojo ibérico (Discoglossus galganoi) Otro endemismo occidental presenta una distribución limitads al cuadrante noroccidental de la Península, como la salamandra rabilarga (Chioglossa lusitanica). Otro grupo son los endemismos meridionales de la mitad sur de la Península. Son los recientemente descritos tritón pigmeo (Triturus pygmaeus) y sapillo moteado meridional (Pelodytes ibericus). Un subgrupo bien diferenciado corresponde a especies limitadas a las regiones montañosas del sur peninsular, como es el sapo partero bético (Alytes dickhilleni) y, parcialmente, el sapo partero ibérico (Alytes cisternasii). El sapiIlo pintojo meridional (Discoglossus jeanneae) es un endemismo del sur peninsular, pero con una distribución mucho más extensa que alcanza amplias áreas de la mitad oriental de Iberia. El último grupo son los endemismos pirenaicos como la rana pirenaica (Rana pyrenaica), el tritón pirenaico (Calotriton asper, antes Euproctus asper), y el tritón del Montseny (Calotriton arnoldi), con una reducidísima distribución en esta sierra prepirenaica catalana.

La herpetofauna balear es muy importante. La riqueza de anfibios y reptiles del archipiélago balear es relativamente baja, sobre todo en lo referente a endemismos, 
ya que éstos incluyen en la actualidad sólo un anfibio anuro, el ferreret o sapillo balear y 2 de lagartijas. Otros anfibios endémicos se extinguieron un los últimos cientos de años, probablemente por la introducción de depredadores en las Baleares, como el sapo partero de Menorca, Alytes talaioticus, emparentada con el ferreret, y de un Discoglósido del grupo de los sapillos pintojos. En Baleares existen hasta 13 especies de anfibios y reptiles introducidos y numerosos mamíferos (gastos, ratas, comadreja, etc.) o serpientes. Su impacto ha sido enorme y ha llevado a la extinción o casi extinción de varios herpetos.

En las islas Canarias no hay anfibios autóctonos dado su carácter volcánico y aislamiento del continente africano y a que los anfibios son malos colonizadores a través del océano. Varias especies de anfibios se han asentado en las Canarias, especialmente la rana verde común (Pelophylax perezi) y la ranita meridional (Hyla meridionalis) que podría haber llegado de África directamente o a través de la Península Ibérica. En los territorios del Norte de África existen varias especies de anfibios, entre los que destacaríamos a la salamandra norteafricana (Salamandra algira) o el sapo moruno (Bufo mauritanicus) y otras que tienden a separarse específicamente de los de Iberia. Así el sapo partero moruno (Alytes maurus), el gallipato, sapo de espuelas, etc.

Con respecto al estado de conservación de los anfibios españoles, tenemos varios niveles que examinar. En cuanto al Catálogo nacional de especies amenazadas, sólo una especie, Alytes muletensis, el ferreret de Mallorca se considera en peligro de extinción. Salamandra algira, la salamandra norteafricana se considera Vulnerable. Claramente, el CNEA se halla desfasado en el caso de los herpetos con respecto al conocimiento del estado de conservación proporcionado por las categorías de la UICN. Márquez \& Lizana (2002) en su revisión de las categorías del libro rojo (en Pleguezuelos, 2002) y la posterior revisión de la AHE de 2004, recogen a una especie de anfibio en Peligro crítico, 3 en peligro de extinción, 8 vulnerables y 10 Casi amenazadas.

El ferreret es un endemismo de la isla de Mallorca, con una distribución actual limitada a una reducida área de la Sierra de Tramontana. Todas las localidades conocidas se incluyen en una pequeña área de cañones cársticos. La regresión del ferreret se debió históricamente a la introducción antrópica de fauna, en especial la culebra de agua viperina (Natrix maura) y la rana verde común ( $P$. perezi). Se la considera en Peligro crítico (CR). Sin embargo, se ha propuesto su paso a Vulnerable por el gobierno balear (AHE, 2005) debido a la mejora en su estado de conservación. El ferreret ha sido objeto de un plan de recuperación desde mediados de los 80 .

Anfibios en peligro de extinción (AHE, 2005) son Rana pyrenaica, elevada desde Vulnerable, Salamandra algira (que se mantiene como EN) y Rana dalmatina. Entre las vulnerables, citaremos a Chioglossa lusitanica, Salamandra salamandra, Mesotriton alpestris, Triturus pygmaeus, Alytes dickhillenii, Rana iberica y Bufo viridis o Bufo baleari78 cus, según se considere a nivel de especie o no. 
Rana pyrenaica es endémica de la región pirenaica centro-occidental (Navarra y Aragón). Las localidades conocidas se han hallado en la vertiente sur de los Pirineos. Es una especie torrentícola, que suele vivir en aguas corrientes frías, oxigenadas, poco eutróficas y sin presencia de truchas, y en fuentes, abrevaderos, aljibes y charcas con renovación hídrica. Rana dalmatina, la rana ágil, tiene una pequeña población española que constituye el borde suroccidental de distribución de la especie, y que se encuentra severamente fragmentada con un declive continuo en la extensión y calidad del hábitat y en el número de subpoblaciones. Con respecto a Salamandra algira, tiene una distribución exclusivamente norteafricana, Ha sido descubierta recientemente en Ceuta. Debido a su distribución puntual y muy localizada, y con reducidos efectivos poblacionales, es extremadamente frágil y vulnerable.

Diversas especies consideradas en 1992 como No amenazadas "NA" han aumentado su categoría de amenaza a Vulnerable "VU" al disponerse de una información más detallada sobre su distribución, estado de las poblaciones (Márquez \& Lizana, 2002; AHE, 2005) y/o haberse detectado un fuerte declive en los últimos años. Entre los anfibios Salamandra salamandra, con numerosas poblaciones amenazadas y Rana iberica, con un notable descenso en su número de poblaciones y abundancia en gran parte de su distribución. Otros cambios son menos drásticos, pero están en la línea del aumento de amenaza desde la categoría de no amenazado "NA" a casi amenazado "NT". Entre los anfibios se hallan Calotriton asper, Pleurodeles waltl, Alytes cisternasii, A obstetricans y Discoglossus jeanneae.

Con respecto a la directiva de Hábitats, 4 especies se encuentran en el Anexo II. y se consideran de interés prioritario por ser endémicas y estar muy amenazadas. Para su conservación es necesario designar Zonas de Especial Conservación (ZECs). Dieciséis anfibios españoles se encuentran catalogadas como de interés comunitario que requieren una protección estricta (anexo IV).

\section{Los reptiles españoles}

Se han citado 87-88 especies de reptiles en el territorio español. La cifra es difícil de concretar pues por un lado se están describiendo constantemente nuevas especies de lagartijas ibéricas y canarias (también eslizones) mediante técnicas moleculares, pero también porque incluimos en esta lista a las especies de los territorios norteafricanos y a las tortugas marinas que se encuentran, pero no nidifican, en las costas españolas (salvo una especie, la tortuga boba, que lo hace puntualmente).

Los reptiles pertenecen a grupos muy variados morfológicamente como son las tortugas, lagartos, serpientes, eslizones, camaleones, etc. Los Quelonios o tortugas españoles son 9 especies, prácticamente todas amenazadas en diverso grado, y que incluyen 5 tortugas marinas, Chelonia mydas, Eretmochelys imbricata, Lepidochelys kempii, Dermochelys coriacea y Caretta caretta. Sólo la tortuga boba (Caretta caretta) se reproduce todavía puntualmente en las costas españolas. Existen también 2 tortu- 
gas terrestres en la Península y Baleares, la tortuga mora (Testudo graeca) y la tortuga mediterránea (T. hermanni); y dos galápagos o tortugas acuáticas de agua dulce. El galápago común (Mayremys leprosa) y el europeo (Emys orbicularis). También hay diversas tortugas exóticas introducidas, en número y cantidad creciente, entre las que destaca por su presencia el galápago de Florida o tortuga de orejas rojas (Trachemys scripta). Ninguna tortuga es endémica del territorio español, pero resultan de interés prioritario desde el punto de vista de la conservación.

El otro gran grupo de reptiles son los Escamosos, con diversos grupos y familias. Un grupo peculiar es el de los Anfisbénidos, reptiles sin patas con aspecto de lombriz, cavadores y ciegos. En nuestra fauna encontramos 3 especies; en la Península la culebrilla ciega (Blanus cinereus) y 2 en el Norte de África, la culebrilla ciega de Tánger (Blanus tingitanus) y la culebrilla mora (Trogonophis wiegmanni).

La familia de los Camaleones está representada por el camaleón común (Chamaeleo chamaeleon) del sur de Iberia y Norte de África. La familia Ánguidos incluye en la Península Ibérica una sola especie ápoda, sin patas, con aspecto de serpiente. Es el lución o culebra de cristal (Anguis fragilis) dada la capacidad de autotomizar su cola. No se halla en Baleares o Canarias.

La familia de los eslizones (Escíncidos) se compone de 12 especies, al menos 2 en la Península ibérica, Chalcides striatus y el endemismo ibérico Chalcides bedriagai; 3 especies endémicas de Canarias, la lisneja (Chalcides simonyi), la lisa variable (Ch. sexlineatus) y la lisa dorada (Ch.viridanus); y al menos 7 especies en los territorios del norte de África o transfretanos (Novoumeces algeriensis, Chalcides colosii, Ch.mauritanicus, Ch.minutus, Ch.ocellatus, Ch. parallelus y Ch. pseudostriatus).

Las salamanquesas o gecos (familia Gecónidos o Gekónidos) presenta al menos 7 especies en territorio español, 2 de ellas en la Península y Baleares, la salamanquesa común (Tarentola mauritanica) y la rosada (Hemidactylus turcicus). En Canarias hay al menos 4 especies endémicas del archipiélago, el perenquén o salamanquesa majorero (Tarentola angustimentalis), perenquén de Boettger ( $T$. boettgeri), perenquén común (T.delalandii) y el pracan o perenquén de Gomera (T. gomerensis). Por último, hay al menos una especie en el Norte de África e isla de Alborán, el geco de Alborán (Saurodactylus mauritanicus).

La familia de los Agámidos (familia típicamente africana) incluye 1 especie de lagarto africano, el agama de Bibrón (Agama impalearis) en Melilla y Norte de África. La familia de los Lacértidos (lagartijas y lagartos típicos) consta al menos de 36 especies, aunque este número sigue aumentando con las descripciones recientes y las previstas de nuevas especies. Al menos 22 especies se encuentran en la Península Ibérica., Una es exclusiva de las islas Columbretes, frente a Castellón (Podarcis atrata, antes subespecie de $P$.hispanica). Al menos 8 especies son lagartos endémicos de Canarias (género Gallotia), 2 endémicas de Baleares y 2 introducidas; y 2 lagartijas del Norte de 80 África (Podarcis vaucheri), antes subespecie de $P$. hispa 
En la Península ibérica citaremos a la lagartija colirroja (Acanthodactylus erythrurus), el endemismo español lagartija de Valverde (Algyroides marchi), lagarto ágil del Pirineo (Lacerta agilis), lagarto ocelado (Lacerta lepida; para otros autores Timon lepidus), el endemismo ibérico lagarto verdinegro (Lacerta schreiberi), lagarto verde (Lacerta bilineata), lagartija de turbera Lacerta (Zootoca) vivipara. También encontramos a la lagartija de Marruecos (Lacerta perspicillata), introducida en la isla de Menorca.

En la Península Ibérica encontramos también varias grandes lagartijas que han sufrido un cambio espectacular en su taxonomía en los últimos 10 años. De la antigua consideración de una sola lagartija serrana (Lacerta monticola) con poblaciones en Pirineos, Cordillera Cantábrica, Galicia y Sistema Central, se ha pasado a un complejo de al menos 6 especies agrupados en el género Iberolacerta, emparentado con lagartijas del Cáucaso. Todas ellas son endemismos españoles, o bien un endemismo ibérico en el caso de I. monticola, pues se halla en Portugal.

En la actualidad sólo se mantiene el nombre I. monticola para las poblaciones de Galicia, Cordillera Cantábrica y Sierra de la Estrella en Portugal. Las poblaciones del Pirineo que antes se consideraban una subespecie ( $L$. $m$. bonnali $)$ se han elevado a rango específico (Iberolacerta bonnali, I. aurelioi, I. aranica). Las "monticola” del Sistema Central se han diferenciado en dos especies: I.cyreni (Guadarrama y Gredos) e I. martinezricai (Peña de Francia, Salamanca). La especie de la Peña de Francia, con una distribución y efectivos poblacionales muy reducidos, estaría en peligro de extinción y sería más próxima a las poblaciones cantábricas (I. monticola) que a las del Sistema Central (I. cyreni). Una de las últimas especies descritas (año 2006) de lagartijas es la lagartija leonesa (Iberolacerta galani), especie endémica de los Montes de León, en las provincias de León, Zamora y Orense.

El género Podarcis tiene al menos 10 especies descritas, 7 ibéricas, 2 en Baleares y 1 introducida. Las especies ibéricas son los endemismos ibéricos lagartija de Bocage (Podarcis bocagei) y lagartija de Carbonell (Podarcis carbonelli), el endemismo español de las islas Columbretes ( $P$.atrata) y la lagartija roquera ( $P$. muralis), de amplia distribución europea. Por último la lagartija ibérica, el taxón "Podarcis hispanica", es en realidad un complejo de 4-5 especies que están aún por describir. Por ejemplo, la lagartija andaluza (Podarcis vaucheri), diferenciada recientemente de P.hispanica, se encuentra a ambos lados del Estrecho de Gibraltar, en Andalucía (Cádiz) y Norte de África, con una cierta diferenciación genética entre ambas poblaciones.

Dos especies de lagartijas del género Podarcis son endemismos del archipiélago balear y presentan una gran diferenciación subespecífica en los islotes que rodean las Baleares, etando algunas poblaciones muy amenazadas. Son la lagartija de las Pitiusas ( $P$. pityusensis) y la lagartija balear ( $P$.lilfordi). Por último, hay 1 lagartija introducida, la lagartija italiana (Podarcis sicula) que se halla en la isla de Menorca, en el puerto de Almería y en Santander. 
El género Psammodromus incluye 3 especies en España, la lagartija cenicienta (Ps. hispanicus) que se ha dividido muy recientemente en dos especies, aunque existe un debate sobre la aceptación de esta división a nivel específico o subespecífico (ver www.vertebradosibericos.org/reptiles). Son la lagartija colilarga occidental (Ps. manuelae) presente en la mayor parte de las regiones occidentales de la Península Ibérica excepto en el extremo norte. La otra es la lagartija colilarga oriental (Ps. jeanneae) presente en la mayor parte de las regiones orientales de la Península Ibérica.

Los lagartos canarios forman un grupo interesantísimo desde el punto de vista de su evolución, como de su conservación y la historia de su descubrimiento e incluso proceso de extinción. Son 6 especies actuales y alguna(s) extintas pertenecientes al género Gallotia, próximo al género Psammodromus. Los antecesores de los lagartos canarios llegaron de la cercana costa africana en balsas naturales diferenciándose rápidamente en las diversas islas del archipiélago.

Las especies actuales son el lagarto atlántico (Gallotia atlantica), lagarto de Lehrs (G. caesaris), lagarto tizón (Gallotia galloti), lagarto canario moteado (G. intermedia) y varios lagartos llamados "gigantes" por el gran tamaño que alcanzaban antes de la llegada del hombre y de los depredadores introducidos a las Canarias, y que todavía alcanzan. Son el lagarto gigante de Gran Canaria (G.stehlini) y varios en peligro critico de extinción como el lagarto gigante de El Hierro (G.simonyi), de La Gomera (G. gomerana) y de La Palma (G. auaritae).

Los Ofidios o serpientes incluyen 13 especies autóctonas en la Península Ibérica (3 de ellas también en Baleares). Hay algunas citas de serpientes en el Norte de África, pero las citas son antiguas o dudosas y por ello no las recogeremos aquí. La nomenclatura de las serpientes españolas ha cambiado notablemente en los últimos años (AHE, 2009), especialmente a nivel genérico. Existen 10 especies pertenecientes a la familia Colúbridos y 3 a los Vipéridos o víboras. Entre las culebras citaremos a la culebra de herradura (Hemorrhois hippocrepis), culebra verdiamarilla (Hierophis viridiflavus), culebras lisas europea (Coronella austriaca) y meridional (Coronella girondica), culebra de cogulla occidental (Macroprotodon brevis), culebra de Esculapio (Zamenis longissimus), culebra de escalera (Rhinechis scalaris), culebra bastarda (Malpolon monspessulanus) y las culebras de agua culebra viperina (Natrix maura) y de collar (Natrix natrix). Las 3 víboras son la víbora áspid (Vipera aspis), la víbora hocicuda ( $V$. latasti) y la única serpiente endémica de la Península ibérica, la víbora cantábrica ( $V$. seoanei). Vipera latasti y Natrix maura se hallan también en el Norte de África.

Desde su origen volcánico a principios del Mioceno, el Archipiélago Canario ha estado totalmente aislado del continente Africano y eso ha quedado reflejado en la composición de su fauna, muy rica en endemismos. Recordemos que aún sin anfibios autóctonos en Canarias, hay al menos 15 especies autóctonas de reptiles (lagartos, eslizones, perenquenes), sin contar a las tortugas marinas. Gallotia es un género endémico de las islas, con al menos un representante en cada una de las islas mayores y 82 en casi todos los islotes. La llegada del hombre y sus acompañantes habituales (ga- 
tos, ratas, etc.) supuso romper el frágil equilibrio de las islas, afectando especialmente a las especies más vulnerables o quizá apetecibles (como los lagartos gigantes).

La intensa depredación que ejercen las ratas, los perros y, sobre todo, los gatos sobre los lagartos herbívoros gigantes, unidos al pequeño tamaño de puesta y a la tardía madurez reproductora, han llevado a una situación crítica a Gallotia auaritae, $G$. bravoana, G. intermedia o G. simonyi. Los recientes descubrimientos de algunas especies que se suponían extintas hasta ahora en islas como Tenerife, La Gomera o La Palma y el establecimiento de planes de recuperación para las especies más amenazadas, los lagartos gigantes del Hierro y Gomera muestran la actividad a favor de la protección de estas especies.

Las islas Baleares recogen en las islas principales e islotes al menos 13 especies de herpetos actuales, 3 autóctonas y 10 introducidas. Las autóctonas son la representación actual de la exclusiva fauna plio-pleistocénica de vertebrados terrestres que ocupó las islas antes de la llegada del hombre. Son el ferreret y 2 lagartijas endémicas, Podarcis lilfordi y P.pityusensis. Como especies introducidas por el hombre están la ranita meridional, la rana verde común, la lagartija de Marruecos, la lagartija italiana, el galápago europeo y ambas tortugas terrestres, la mora y la mediterránea. Entre las serpientes introducidas están la culebra viperina, la culebra de escalera y la culebra de cogulla.

En los territorios españoles del Norte de África: Ceuta, Melilla, Islas Chafarinas, Peñón de Alhucemas y Peñón de Vélez de la Gomera podemos señalar una alta riqueza de especies (se han citado al menos 11 especies) en una superficie muy pequeña y en general una alta densidad de población. Entre las especies de Ceuta podemos citar a Salamandra algira (en peligro), Hyla meridionalis, varios Chalcides., Blanus tingitanus, Trogonophis wiegmanni, Testudo graeca, Mauremys leprosa, Chamaeleo chamaeleon, Hemorrhois hippocrepis, y como tortugas marinas Caretta caretta y Dermochelys coriacea. La información sobre Melilla, Chafarinas, etc.,revela que hay varios reptiles de dudosa presencia actual como Lacerta tangitana, Psammodromus blanci, Mesalina olivieri, Mesalina guttulata, Psammophis schokari y Vipera latasti. Las islas Chafarinas con varias especies de Chalcides es Zona de Interés Herpetológico Importante en el Inventario de las Áreas Importantes para los Anfibios y Reptiles de España.

\section{Estado de conservación de los reptiles según las categorías UICN}

El libro rojo de los reptiles españoles se actualizó por Márquez \& Lizana (2002) y posteriormente la AHE ha revisado dichas categorías en el año 2005. Cinco especies se encuentran en peligro crítico CR, 6 en peligro (EN), 12 son Vulnerables (VU) y 10 Casi amenazadas (NT). Varios taxones se hallan en Peligro Crítico "CR". Entre ellos la tortuga laud, la tortuga carey Eretmochelys imbricata y el lagarto canario Gallotia simonyi. La tortuga marina Caretta caretta, Testudo graeca, Testudo hermanni y Chelonia mydas se hallan en peligro de extinción "EN". Diversos taxones se hallan en la 
categoría de Vulnerable "V", como Emys orbicularis, Chalcides mauritanicus, Ch.paraIlelus, Ch. simonyi, Podarcis lilfordi, Algyroides marchi y Lacerta bonnali.

Algunas especies recientemente descritas se hallan también amenazadas. En los reptiles se consideran en peligro crítico (CR) a Iberolacerta martinezricai, Iberolacerta aranica (Pirineos), Gallotia intermedia (Tenerife) y Gallotia bravoana (Gomera). Iberolacerta aurelioi, también de reciente descripción, se cataloga en un grado de amenaza menor, en peligro "EN".

Diversas especies consideradas en 1992 como no amenazadas "NA" han aumentado su categoría de amenaza a vulnerable "VU" Son los eslizones Chalcides colosii y Ch. pseudostriatus. También en el galápago Mauremys leprosa, considerado anteriormente común, se aprecia un notable declive. En el mismo sentido podemos señalar a Podarcis atrata, pasando de NA a Vulnerable "VU".

Diversos reptiles se consideran casi amenazados "NT", como Chalcides bedriagai, Iberolacerta monticola, Lacerta schreiberi o Zootoca vivipara. Especialmente significativo es el caso de dos serpientes, Macroprotodon brevis y Vipera latasti.

Como casos más significativos en cuanto a la disminución en su categoría de amenaza, está el del Camaleón, que ha pasado de considerarse en peligro de extinción en 1992 a la categoría de casi amenazado "NT". El amplio número de expertos consultados avala este brusco cambio. Por otro lado, Lacerta agilis ha pasado de vulnerable "V" a casi amenazado "NT" y Podarcis pityusensis ha pasado de rara " $\mathrm{R}$ " a vulnerable "VU".

\section{Los anfibios y reptiles introducidos en España}

En el territorio español, para tratar a las especies de anfibios y reptiles introducidas debe considerarse la época de su introducción, y su estatus reproductor en la naturaleza. Hay un grupo de especies de introducción antigua que se remonta en algunos casos hasta el Neolítico. Son el sapillo pintojo, sapo moruno, tortuga mora, camaleón común y lagartija italiana en la Península Ibérica; sapo verde, ranita meridional, rana común, galápago europeo, tortuga mora, tortuga mediterránea, salamanquesa común, salamanquesa rosada, lagartija italiana, lagartija de Marruecos, culebra de escalera, culebra de cogulla, culebra viperina, en las Islas Baleares; ranita meridional, rana común y salamanquesa rosada, en las Islas Canarias.

El grupo de especies de introducción reciente comprende a aquellas que llegaron a nuestro territorio en la últimas décadas: rana toro, galápago americano o de Florida, perenquén de Boettger, lagartija de la Pitiusas, en la Península Ibérica; galápago americano, lagartija cenicienta, en los territorios españoles del Norte de Áfri84 ca; rana magrebí, iguana común, correcaminos arleguín, en las Islas Canarias; lagartija colilarga en las Islas Baleares; sapo común, en los dos archipiélagos. 
Poblaciones de algunas especies han sido traslocadas dentro de España a comarcas o regiones donde no se conocía su presencia de forma natural. Es el caso del gaIlipato, tritón alpino, tritón palmeado, tritón jaspeado, ranita meridional, sapo común, lagartija cenicienta, lagarto verde, galápago leproso, dentro de la Península Ibérica; sapo verde, lagartija de las Pitiusas, lagartija balear, dentro de las Islas Baleares; lisa dorada, lagarto atlántico, lagarto tizón de La Gomera y El Hierro, lagarto tizón, lagarto de Gran Canaria, dentro de las Islas Canarias.

Además, se han econtrado hasta 28 especies no nativas en la naturaleza ( 5 anfibios, 23 reptiles), pero solo como especies aclimatadas, puesto que no se han encontrado pruebas de su reproducción. La mayoría de ellas son especies típicas utilizadas como animales de compañía. Las regiones españolas con el mayor número de especies no nativas fueron las insulares, las islas Baleares y las Canarias. La mayoría de las especies no nativas en esas islas fueron introducidas durante el Neolítico y la Edad Antigua (por ejemplo, 13 de las 16 especies no nativas en las Islas Baleares). Especies con un importante tamaño corporal y/o significado religioso para las culturas antiguas (por ejemplo, quelonios, ofidios), fueron introducidas deliberadamente, mientras que lo contrario sucedió para las especies con pequeño tamaño corporal (gecos, lagartijas).

En conclusión, el escenario para la problemática de las especies de anfibios y reptiles introducidos en España no es aún dramático, pero medidas administrativas podrían y deben ser tomadas para controlar o erradicar estas especies, especialmente en el caso de las invasoras, como el galápago americano.

\section{LAS AVES ESPAÑOLAS}

La avifauna española es una de las más ricas e interesantes de Europa. Las aves son los vertebrados terrestres más numerosos en España (aprox. 521 especies), aunque por detrás de los peces marinos. Para este trabajo-resumen utilizaremos principalmente los datos del Atlas de las aves de España (Purroy, 1997), el Atlas nacional de las aves reproductoras (Martí \& del Moral, 2003); y el Libro rojo de las aves de España (Madroño et al., 2004) así como el capítulo de aves del libro “La naturaleza en España" de de Juana (2002). La mayor parte de los atlas y trabajos generales sobre las aves españolas se refieren únicamente a las aves reproductoras o nidificantes en el territorio español, pero no olvidemos que también hay numerosas especies migratorias de paso o que vienen a invernar o a estivar, pero no se reproducen aquí.

Cuantificar el número exacto de aves españolas es por tanto una empresa difícil, ya que depende de criterios geográficos, del concepto de especie y del grado de conocimiento y estudio del territorio. La cifra ha ido aumentando desde que Francisco Bernis publicara en 1954 la primera lista patrón de las aves españolas (incluyendo Baleares y Canarias). Bernis citaba 404 especies, mientras que en el atlas de Purroy (1997) se da la cifra total de 521. En el último atlas nacional (Martí \& del Moral, 2003) 
se recogen como especies reproductoras un total de 337 aves, frente a las 700 aproximadamente citadas en Europa occidental, es decir más del 50\% de las europeas. En Europa occidental se estima en unas 412 especies las aves nidificantes (De Juana, 2002), por lo que España tendría una alta proporción (80\%) de las aves que se reproducen en Europa. Si comparamos la avifauna nidificante española con la de otros países de Europa occidental comprobamos que es similar, o ligeramente superior con los datos actuales a la de países mediterráneos de tamaño similar como Francia o Grecia.

Generalmente se distinguen dentro de las reproductoras a las nativas o autóctonas y las introducidas por la acción humana (voluntaria o involuntariamente), que se reproducen en libertad. Como especies nativas se consideran aquellas que crían habitualmente en España, y que se han detectado desde el año 1985 a 2002.

TABLA 11

Especies que nidifican regularmente en diferentes países de Europa

\begin{tabular}{|l|c|c|}
\hline & Especies nidificantes & Especies/1.000 km² \\
\hline España (Península y Baleares) & 254 & 0,51 \\
\hline Francia (continente y Córcega) & 259 & 0,48 \\
\hline Grecia & 237 & 1,80 \\
\hline Polonia & 218 & 0,70 \\
\hline Reino Unido & 193 & 0,79 \\
\hline Rumanía & 233 & 0,99 \\
\hline Suecia & 237 & 0,53 \\
\hline
\end{tabular}

Tomado de De Juana, 2002.

Un total de 288 especies se consideran nativas, algunas de reproducción muy ocasional o sólo posible; y 49 son especies introducidas, aunque esta relación no es exhaustiva y no todas son reproductoras habituales. Se ha obtenido una media de 75 especies de aves por cuadrícula UTM de $10 \times 10 \mathrm{Km}$. De las 288 especies nativas, 266 pueden considerarse reproductoras habituales, aunque algunas con poblaciones muy pequeñas. Otras 17 especies nativas son reproductoras sólo posibles u ocasionales, como colonizadoras recientes o que habrían pasado desapercibidas como reproductoras. Para otras 5 especies no hay información concluyente sobre su estatus reproductor.

De las 49 aves introducidas (voluntaria o accidentalmente), 6 se reproducen habitualmente en España y han dado lugar a poblaciones reproductoras autosostenibles. Otras 43 especies introducidas no se han establecido todavía como reproducto86 ras regulares en España, pero se han reproducido esporádicamente. 
La avifauna peninsular es rica en aves reproductoras e invernantes, aunque no cuenta con edemismos peninsulares debido a su capacidad de dispersión, por ejemplo comparando con los herpetos o pequeños mamíferos. Endemismos ibéricos que casi lo son españoles son el águila imperial ibérica (Aquila adalberti), con muy escasa o nula reproducción en Portugal y Marruecos, y el mosquitero ibérico (Phylloscopus brehmii), que además de en Iberia cría sólo en una reducida parte de Francia. El resto de aves ibéricas se extienden por áreas más o menos extensas de Europa y África.

\section{La importancia de Baleares y Canarias}

Al comparar la riqueza de aves de la Península con las islas Baleares y las Canarias, podemos observar que de acuerdo a un principio biogeográfico básico, la riqueza de aves es menor en las islas que en el continente, pero que los archipiélagos canario y balear tienen más endemismos, incluso en un grupo de gran capacidad de desplazamiento como las aves. La siguiente tabla, tomada del atlas de 1997 (Purroy, 1997) y por tanto no actualizada, muestra como el porcentaje de endemismos es del $8,7 \%$ en las Canarias, mientras que no hay ningún taxón endémico en la Península Ibérica.

Hay que destacar la gran importancia de la avifauna canaria por la proporción de sus endemismos a nivel específico y subespecífico. Como parte integrante de la región biogeográfica Macaronésica, las Canarias presentan un gran porcentaje de sus seres vivos exclusivos o compartidos únicamente con los vecinos archipiélagos de Madeira y Azores. Entre las aves endémicas pueden destacarse a las palomas turqué (Columba bollii) y rabiche (Columba junionae), la tarabilla canaria (Saxicola dacotiae) y el pinzón azul (Fringilla teydea) en Tenerife, y la subespecie F. t. polatezki, amenazada de extinción, en Gran Canaria. También fue único en el mundo el ostrero canario, probablemente extinguido por la llegada de los humanos a las islas. Son también endemismos macaronésicos el vencejo unicolor, el bisbita caminero y el canario, origen de las aves domésticas canoras.

TABLA 12

Número de especies de aves nidificantes regulares en España

\begin{tabular}{|l|c|c|c|c|}
\hline \multicolumn{1}{|c|}{ Territorio } & N. $^{\circ}$ total & $\begin{array}{c}\text { N. }{ }^{\circ} \text { no } \\
\text { compartidas }\end{array}$ & $\begin{array}{c}\mathbf{N}^{\circ} \text { endémicas }^{\circ} \\
\text { endémicas }\end{array}$ & $\begin{array}{c}\% \text { de } \\
\text { endém }\end{array}$ \\
\hline Península & 252 & 143 & 0 & 0,0 \\
\hline Baleares & 96 & 2 & 1 & 1,0 \\
\hline Canarias & 69 & 17 & 6 & 8,7 \\
\hline España & 272 & & 7 & 2,6 \\
\hline
\end{tabular}

Tomado de De Juana, 2002. 
Toda una serie de aves canarias se hallan más o menos diferenciadas de las continentales y existen dudas sobre si considerarlas subespecies o verdaderas especies. Citaremos algunas como el reyezuelo tinerfeño o canario, el mosquitero canario, las razas insulares del pinzón vulgar o el herrerillo. La gran variedad de altitudes, hábitats y paisajes determinan una avifauna diversa para cada isla canaria y otras especies comunes a todas ellas, como el cernícalo vulgar, el triguero, la tarabilla canaria o la chova piquirroja. Diversas especies migratorias recalan en las Canarias, algunas regular y otras accidentalmente. Varias aves de climas desérticos africanos ocupan las islas más orientales, como el corredor sahariano y la avutarda hubara. Varias aves marinas son únicas en España, por ejemplo el petrel de Bulwer, la pardela pichoneta, la pardela chica, el paíño de Madeira y el paíño pechialbo.

Entre las aves de las Baleares de mayor interés figuran las aves marinas, en especial una especie considerada endémica y en peligro de extinción, la pardela balear. Los acantilados costeros de las islas Baleares concentran las zonas de reproducción del halcón de Eleonora. Otras especies a destacar son la curruca sarda, que sólo vive en Cerdeña y Baleares, y que presenta en Baleares una subespecie endémica (Sy/via sarda balearica). Existen otras aves diferenciadas como el papamoscas gris. Las aves que nidifican de manera regular en las Baleares no llega al centenar de especies. Pueden desatacarse algunas marinas como la pardela cenicienta, paíño europeo, cormorán moñudo, gaviota de Audouin y dos aves rapaces ligadas al mar, el águila pescadora y el halcón de Eleonora.

\section{El estado de conservación de las aves españolas}

Utilizaremos aquí principalmente los datos del libro rojo de las aves españolas (Madroño et al., 2004), mostrando sólo algunos ejemplos de la aves más amenazadas, en peligro crítico o en peligro de extinción según las categorías de la UICN, dado el gran número de especies que impide un comentario detallado de todas ellas.

Dos aves españolas endémicas se han extinguido desde el siglo XIX: el ostrero canario (Haematopus meadewaldoi) y la tarabilla canaria (Saxicola dacotiae murielae) subespecie de las islas de Montaña Clara y Alegranza. El resto de los taxones extinguidos lo eran a nivel regional, y aunque ya no forman parte de la avifauna española sobreviven en otras regiones. El 25\% de la avifauna reproductora española (391 taxa, considerando especies y subespecies) se considera amenazada en diversas categorías (CR, EN, VU), el 8\% (32 taxa) "Casi Amenazadas" (NT), y el 6\% (25 taxa) se halla en la categoría de “Datos Insuficientes” (DD).

Los 15 (3,8\%) taxones de aves considerados según las categorías UICN como en Peligro Crítico tienen un alto riesgo de extinción en un futuro próximo (probabilidad $>50 \%$ en las próximas tres generaciones). Comentaremos muy brevemente la situación de las especies más amenazadas ( $C R$ y EN) y/o emblemáticas, especialmente 88 aquellas que sean endemismos españoles o ibéricos. Entre ellos destacan los ende- 
mismos españoles de Baleares o Canarias, para los que España tiene un alto grado de responsabilidad pues su extinción supondría una extinción global. Son la pardela balear (Puffinus mauretanicus), el alimoche canario o guirre (Neophron percnopterus majorensis), la subespecie canaria de terrera marismeña (Calandrella rufescens) y el pinzón azul de Gran Canaria (Fringilla teydea polatzeki).

\section{FIGURA 5}

Datos alusivos al número de taxones de aves amenazadas. Tomado del Libro rojo de las aves españolas (Madroño et al, 2004)

\begin{tabular}{|c|c|c|c|c|c|c|c|c|c|}
\hline \multirow{2}{*}{\multicolumn{5}{|c|}{$\begin{array}{l}\text { TABLA 2. NÚMERO DE TAXONES QUE HAN } \\
\text { CALIFICADO PARA CADA UNA DE LAS } \\
\text { CATEGORIAS DE LA UICN }\end{array}$}} & \multicolumn{5}{|c|}{ Tabla 2b: Taxones con "problemas de conservación" } \\
\hline & & & & & $\mathrm{CR}$ & 15 & & & \multirow{5}{*}{$40 \%$} \\
\hline \multicolumn{5}{|c|}{ Tabla 2a } & $\mathrm{EN}$ & 39 & $25 \%$ & $34 \%$ & \\
\hline EX & 2 & $1 \%$ & \multirow[b]{2}{*}{9} & \multirow{3}{*}{$5 \%$} & vo & 45 & & & \\
\hline RE & 7 & $4 \%$ & & & NT & 32 & & & \\
\hline $\mathrm{CR}$ & 15 & $9 \%$ & \multirow{3}{*}{99} & & DD & 25 & & & \\
\hline EN & 39 & $22 \%$ & & \multirow{2}{*}{$57 \%$} & Totales & \multicolumn{2}{|l|}{156} & & \\
\hline vU & 45 & $26 \%$ & & & \multirow{5}{*}{\multicolumn{5}{|c|}{ 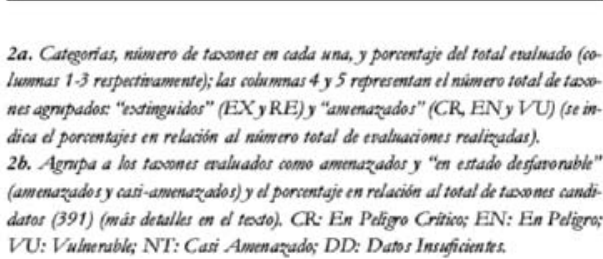 }} \\
\hline NT & 32 & $18 \%$ & 32 & $18 \%$ & & & & & \\
\hline DD & 25 & $14 \%$ & 25 & $14 \%$ & & & & & \\
\hline LC & 10 & $6 \%$ & 10 & $6 \%$ & & & & & \\
\hline \multicolumn{2}{|l|}{ Totales } & $100 \%$ & \multicolumn{2}{|l|}{175} & & & & & \\
\hline
\end{tabular}

El águila pescadora (Pandion haliaetus), En Peligro Crítico, tiene una amplia población mundial. En España tiene una población muy pequeña (años 2001-2002) de unas 30-38 parejas repartidas por los archipiélagos balear y canario).

La pardela balear (Puffinus mauretanicus) se halla En Peligro Crítico. Su distribución se restringe a las islas Baleares (islotes e islas mayores). Las principales amenazas las constituyen los depredadores terrestres y la presión pesquera. Las causas son el declive de la población (7,4\% anual), un área de ocupación efectiva inferior a 10 km² y un tamaño poblacional que no supera las 2.000 parejas reproductoras.

El avetoro común (Botaurus stellaris) se halla En Peligro Crítico. Tiene una población fluctuante y en declive, inferior a 25 territorios. Ha desaparecido como reproductor de numerosas zonas españolas en especial las marismas del Guadalquivir y el delta del Ebro.

El ánsar campestre de la tundra (Anser fabalis rossicus) se considera En Peligro Crítico. Era la especie de ánsar más común en gran parte de España en la pri- 
mera mitad del siglo XX, con una única población invernante en Zamora a finales de los años sesenta, población que prácticamente ha desaparecido durante el invierno del 2000/2001. En los últimos 25 años se han producido sólo citas aisladas y puntuales. El tarro canelo (Tadorna ferruginea), En Peligro Crítico, se ha extinguido como reproductor y prácticamente como visitante post-reproductor en el sur de la península Ibérica. Conserva una población nidificante inferior a seis parejas en Fuerteventura.

La subespecie de alimoche canario (Neophron percnopterus majorensis), En Peligro Crítico, conocida localmente como "guirre" ha sufrido a partir de la década de 1950 un rápido proceso de desaparición en prácticamente todo el archipiélago, donde tan sólo quedarían 25-29 parejas: una en Lanzarote, otra en Alegranza y una última población en Fuerteventura, que aglutina a más del 90\% de la población total, unos 130 individuos.

Otros taxones, como la cerceta pardilla (Marmaronetta angustirostris) tienen aproximadamente un tercio de la población mundial en territorio español. La cerceta pardilla se halla En Peligro Crítico pues ha sufrido una drástica disminución poblacional (notablemente entre los años 1950 y 1990) en sus núcleos principales en Andalucía y Levante, habiendo desaparecido prácticamente como reproductor del PN de Doñana. La pequeña población de 30-200 parejas fluctúa considerablemente en tamaño según los años, y está concentrada en pocos sitios afectados por serias amenazas.

Algo parecido sucede con la focha moruna (Fulica cristata), aunque implicando la extinción de la especie en Europa. Otras especies están muy amenazadas en España pero tienen una amplia distribución geográfica europea o mundial, como el porrón pardo (Aythya nyroca), tarro canelo (Tadorna ferruginea), avetoro (Botaurus stellaris), torillo (Turnix sylvatica), arao común (Uria aalge), ánsar campestre (Anser fabalis rossicus) y alcaudón chico (Lanius minor).

La focha moruna (Fulica cristata) se halla En Peligro Crítico. Cuenta en España con una población inferior a 250 individuos maduros. En la década de 90 dejó de reproducirse en las marismas de Doñana, y las pocas parejas se hallan en varios humedales de Cádiz. Su estado se debe a una combinación de factores, sobre todo la pérdida de calidad del hábitat y la caza accidental por confusión con la focha común.

El torillo andaluz (Turnix sylvatica) se halla también En Peligro Crítico y no hay prácticamente datos en España. La forma mediterránea se encuentra en Marruecos y recientemente hay algunos avistamientos en Andalucía. Si no está extinto, podría estarlo en pocos años.

El porrón pardo (Aythya nyroca) sufre una drástica disminución poblacional, es90 pecialmente en su núcleo principal en las marismas del Guadalquivir, y casi se ha ex- 
tinguido como reproductor ya que en las últimas dos décadas sus poblaciones se reducen a 0-10 parejas, enfrentándose a un alto riesgo de extinción. El torillo andaluz (Turnix sylvatica) se halla En Peligro Crítico en España. La forma mediterránea sigue aún existiendo en algunos puntos de Marruecos y presumiblemente en Andalucía, aunque su supervivencia no está asegurada por muchos años. No existen prácticamente datos sobre la especie.

Treinta y nueve (10\%) taxa de aves españolas se encuentran en la categoría "En peligro" (EN) mientras que $45(11,5 \%)$ taxones son considerados "Vulnerables" (VU) en el libro rojo (Madroño et al, 2004) Un 8\% de la avifauna (32 taxones) se supone como "Casi Amenazado" (NT), lo que nos indica que se encuentran próximas a considerarse amenazadas.

El águila imperial ibérica (Aquila adalberti), En Peligro, es una de las aves emblemáticas al ser un endemismo ibérico. Tiene una población muy pequeña, de unos 350 ejemplares maduros, que se está recuperando en las últimas décadas. Cuenta con tres subpoblaciones con escaso intercambio entre las mismas: una "septentrional" (principalmente el Sistema Central y Extremadura), (62\%) una segunda "central" al sur del Tajo (Montes de Toledo, Tierra de Barros y Sierra Morena), la más pequeña, con un mínimo de 14 ejemplares maduros en las marismas del Guadalquivir. Las mayores amenazas son la disminución del conejo, su presa principal, y la muerte por electrocución en los tendidos eléctricos.

El águila-azor perdicera (Hieraaetus fasciatus), En Peligro, ha desaparecido prácticamente de la meseta norte, quedando poblaciones relictas en Castilla y León, zona centro y Castilla-La Mancha. Las poblaciones del sureste, levantinas y catalanas, han sufrido descensos muy bruscos. Las únicas poblaciones estables se sitúan en zonas de Andalucía y Extremadura. La población cuenta con unas 1.500 parejas.

El halcón tagarote (Falco pelegrinoides pelegrinoides), En Peligro, tiene un mínimo de 75 parejas, restringidas a las Canarias. En la actualidad se encuentra en franco incremento poblacional, probablemente debido a la abundancia de recursos tróficos.

La subespecie de urogallo cantábrico (Tetrao urogallus cantabricus) se halla en Peligro. Ha sufrido un declive continuado durante las últimas décadas (45\% en los últimos 18 años) y en la actualidad probablemente no supera los 500-600 individuos maduros (año 2001). Su área de distribución es inferior a $5.000 \mathrm{~km}^{2}$, se encuentra cada vez más restringida y está a punto de fragmentarse en dos subpoblaciones aisladas (ninguna de las cuales contiene más de 250 adultos). Existe una estrategia nacional reciente para esta subespecie. La subespecie de urogallo pirenaico (Tetrao urogallus aquitanicus) también ha sido calificado como En Peligro. Cuenta con una pequeña población estimada en 1.378 individuos maduros (en 2001) en la vertiente sur pirenaica, El pequeño tamaño poblacional, el declive existente y el grueso de la población concentrada (95\%) en una sola subpoblación. 
El petrel de Bulwer (Bulweria bulwerii) es considerado En Peligro. La población española ha sido cifrada en unas 1.000 parejas reproductoras, repartidas entre todas las islas e islotes del archipiélago canario, a excepción de Gran Canaria y Fuerteventura. La predación por ratas y gatos, y la pérdida de hábitat son las principales amenazas para sus colonias de cría.

La pardela Cenicienta (Calonectris diomedea diomedea) se encuentra En Peligro de extinción porque cuenta con una población reproductora pequeña que está siendo sometida a una mortalidad muy elevada y claramente insostenible a largo plazo. La forma mediterránea se reproduce mayormente en las islas Baleares y Chafarinas, con colonias menores en las Columbretes e islotes de las costas murcianas y andaluzas. La pardela Pichoneta (Puffinus puffinus), tambien En peligro, es una de las aves marinas nidificantes en el territorio nacional más desconocida. Su población ha sido cifrada en algo más de 200 parejas para el conjunto del archipiélago canario. La subespecie de pardela chica (Puffinus assimilis baroli) se halla En Peligro; esta subespecie nidifica en Canarias en Alegranza, Montaña Clara, Lanzarote, Gran Canaria, Tenerife y La Gomera. Su población podría estar por debajo de las 400 parejas.

El paíño de Madeira (Oceanodroma castro), En Peligro, vive en Canarias y su población española es de 550-600 parejas. La tendencia es regresiva, siendo sus principales amenazas la predación por gatos y ratas y las molestias de ciertas actividades humanas. El cormorán moñudo (Phalacrocorax aristotelis aristotelis), En Peligro, se distribuye en España en las costas del mar Cantábrico y Galicia. El total de la población entre 1995-1999 se ha estimado entre 1.700 y 2.900 parejas (un 17\% menos que en censos anteriores.

La malvasía cabeciblanca (Oxyura leucocephala), En Peligro, tiene unos 2.300 individuos y se halla en declive por la expansión de la malvasía canela, una especie americana, introducida en Europa y que hibrida con la cabeciblanca con ejemplares híbridos fértiles. Existe un programa de erradicación de malvasías canelas.

El milano real (Milvus milvus) se halla actualmente En Peligro. En 1994 se realizó el primer censo nacional y ya se detectó una importante regresión. Puede haber sufrido, en tan sólo siete años, una regresión del 50\% en Castilla y León, donde se concentraba alrededor de la mitad de la población en 1994. Extinto recientemente en las islas Canarias, y localmente en varias zonas marginales de la distribución peninsular. En disminución en el resto, con excepción del noreste peninsular. La causa principal parece ser el uso de veneno, al que la especie es muy sensible, tanto al de uso cinegético, como a rodenticidas u otros pesticidas. También es una especie muy sensible a la electrocución y a la desaparición de muladares.

El quebrantahuesos (Gypaetus barbatus), En Peligro, parece mantenerse estable o en ligero crecimiento en el Pirineo, aunque con una población muy pequeña en torno a los 250 individuos maduros. Persisten como amenazas la muerte en 92 tendidos eléctricos y el uso de veneno. El abandono de los usos ganaderos tradi- 
cionales es otro factor desfavorable. El alimoche común (Neophron percnopterus), En Peligro, mantiene en España la mayor población de todo el Paleártico occidental y una de las más importantes del mundo. En España se estima que un mínimo del $25 \%$ de territorios se han perdido entre 1987 y 2000 . Las amenazas principales son los venenos, disminución de presas potenciales, mortalidad en migración e invernada.

Varias aves canarias propias de zonas esteparias y abiertas se hallan en peligro; son la avutarda hubara (Chlamydotis undulata fuertaventurae) que habita en Fuerteventura y está amenazada principalmente por la destrucción y alteración del hábitat, así como por las molestias antrópicas. También pueden citarse en Canarias al corredor sahariano (Cursorius cursor) y dos subespecies canarias del alcaraván común (Burhinus oedicnemus insularum y B.o.distinctus)

Otras especies son emblemáticas de nuestra avifauna, a pesar de no estar tan amenazadas como las anteriores. Por ejemplo casi todas las rapaces se hallan en la categoría de Vulnerable. Destaquemos también a la cigüeña negra (Ciconia nigra), Vulnerable por tener una pequeña población reproductora de aproximadamente 322 parejas seguras distribuidas en el centro y sur occidental de la península Ibérica. El buitre negro (Aegypius monachus) es Vulnerable. Ha aumentado una importante recuperación en las últimas décadas, alcanzando en 2001 unas 1.334 parejas. En Andalucía la tendencia es negativa, debido al envenenamiento de ejemplares. La disminución del conejo, causada por las enfermedades, afecta su disponibilidad como presa para varios depredadores.

Dos aves esteparias se hallan en la categoría de vulnerables, la avutarda y el sisón. La avutarda común (Otis tarda) de amplia distribución Paleártica y que en España se distribuye principalmente por las dos submesetas y, de forma marginal en los valles de los ríos Guadalquivir y Ebro. La población actual se estima en 23.000 individuos, la mayor parte en Castilla y León (46\%), seguida de Extremadura (30\%), CastillaLa Mancha (16\%) y Madrid (5\%). El sisón común (Tetrax tetrax) ha sufrido un fuerte declive en los últimos 20 años. Las amenazas están en la intensificación de la agricultura y cambios en las prácticas agrícolas tradicionales.

La subespecie española de la perdiz pardilla (Perdix perdix hispaniensis) se considera Vulnerable. Esta especie, de la que se permite su caza en varias autonomías a pesar de su delicado estado, se distribuye en 3 núcleos montañosos de la cordillera Cantábrica, el Sistema Ibérico y Pirineos. Las poblaciones se van aislando lo que podría conducir a la extinción local. Las amenazas se relacionan con el declive de las prácticas agropecuarias tradicionales de montaña lo que provoca la recolonización matorral y forestal.

Las principales amenazas para las aves españolas amenazadas (128 taxa en las categorías CR EN, VU y NT) pueden resumirse en varios apartados (Madroño et al, 2004): 
- Destrucción o pérdida de hábitat: Es la amenaza que afecta a un mayor número de taxones (90) entre los que destacan a 8 En Peligro Crítico: el porrón pardo, terrera marismeña, focha moruna, alcaudón chico, cerceta pardilla, pardela balear y torillo. Además, para 62 taxones, esta amenaza se considerada como de importancia alta.

- Molestias humanas: son variadas (actividades deportivas, observación o fotografía de fauna, paseos, circulación fuera de pistas, recoger leña o setas, etc.). Afecta a 53 taxa, de los cuales 4 están como en peligro crítico CR; la terrera marismeña, pinzón de Gran Canaria, alimoche canario y águila pescadora. Para el $36 \%$ de los taxones la importancia de la amenaza es Alta.

- Abandono agrícola e intensificación agrícola y ganadera: La agricultura intensiva con roturación de nuevas tierras, destrucción de lindes y setos, arado profundo, aumento de los fitosanitarios, puesta en regadío, etc. supone la destrucción de lindes y roturación de eriales, afectando especialmente a las aves esteparias y del secano cerealista. Se ven afectados 52 taxones, entre ellos 3 taxones CR y otros $18 \mathrm{EN}$; entre ellos el cernícalo primilla (Falco naumanni), avutarda (Otis tarda), sisón (Tetrax tetras), ganga y ortega y terrera marismeña (Calandrella rufescens).

- Causas naturales: Se incluyen aquí factores ecológicos naturales como la depredación, la competencia interespecífica u otras interacciones entre especies, que normalmente no suponen una amenaza, pero en taxones con distribución y poblaciones muy reducidas puede incrementar la posibilidad de extinción. Siete taxa En Peligro Crítico CR se encuentran en esta situación, entre ellos el pinzón de Gran Canaria, alcaudón chico, torillo y arao.

- Caza insostenible o ilegal: la caza ilegal o furtiva (recordemos que varias comunidades autónomas incumplen todavía la directiva de aves, al permitir el uso de métodos masivos o no selectivos, caza en periodos reproductores, reclamos, etc.) supone una amenaza adicional para taxa en estado crítico CR como el avetoro, alimoche canario y águila pescadora, y para otras emblemáticas como el quebrantahuesos (Gypaetus barbatus) o el águila perdicera (Hieraaetus fasciatus). En este apartado podríamos incluir también el creciente uso ilegal de venenos para combatir a los depredadores como una perversa práctica "cinegética" en la gestión de cotos y que afecta sobre todo a aves carroñeras como el buitre negro y leonado, y a rapaces como el milano real, busardo ratonero, águila imperial y muchas otras especies en menor grado.

- Competencia y depredación por especies introducidas: aquí se incluyen especies introducidas de aves, peces y mamíferos que depredan o compiten con las aves locales, como los animales domésticos asilvestrados o no. Esta es una amenaza frecuente en las aves marinas y en la avifauna canaria en general. Las cuatro especies en estado Crítico afectadas son la terrera marisme- 
ña, pinzón de Gran Canaria, focha moruna y pardela balear. Otras 19 especies catalogadas como En Peligro (EN) también se ven afectadas por esta amenaza.

- Electrocuciones o colisiones en tendidos eléctricos e infraestructuras: los tendidos eléctricos afectan a 24 taxones, teniendo para 10 de ellos una importancia alta. Las especies más afectadas son rapaces y aves grandes y de vuelo lento como la avutarda y el sisón. Tres especies en estado crítico (CR) se ven afectadas, el avetoro, quebrantahuesos y águila pescadora. Las amenazas causadas por otras infraestructuras (parques eólicos, carreteras, etc.) afectan a un amplio número de taxones.

El resto de amenazas (mala gestión del hábitat, quema de rastrojos, reforestaciones, deforestación, destrucción o degradación de riveras, abandono de explotaciones salinas, contaminación lumínica y colisión con alambradas) afectan individualmente a menos de 20 especies, aunque específicamente a algunas especies en peligro como el veneno para el alimoche canario y el milano real.

\section{LOS MAMÍFEROS ESPAÑOLES}

Hemos utilizado para este resumen básicamente la información contenida en el Atlas de los mamíferos terrestres de España (Palomo \& Gisbert, 2002) y la ampliación del mismo "Atlas y libro rojo de los mamíferos terrestres de España (Palomo, Gisbert \& Blanco, 2007) que como su título indica incluye una revisión de las categorías UICN (Libro Rojo). En estas publicaciones no se recoge información sobre los mamíferos marinos españoles (Cetáceos). También se ha utilizado el capítulo de Delibes \& Gisbert (2002) sobre los mamíferos españoles en el libro de Díaz Pineda et al (2002).

Los mamíferos constituyen un grupo de vertebrados terrestres de amplísima distribución geográfica y diversidad morfológica. Se han descrito algo más de 5.400 especies en toda la Tierra y algunos autores indican la cifra de trabajo de 6.000 especies, al tiempo que es evidente que probablemente queden muchos micromamíferos por descubrir en regiones tropicales y/o remotas.

Como en el resto de vertebrados, cuando hablamos de los mamíferos españoles nos referimos al área peninsular, los archipiélagos balear y canario y los territorios norteafricanos. La información disponible es mucho más amplia para los mamíferos terrestres que para los marinos, aunque éstos sean pocas especies en comparación y difíciles de adscribir administrativamente al territorio español. Por último existen diversos mamíferos introducidos o domesticados (hasta 8 especies).

Las comunidades de mamíferos españolas son consecuencia de la historia geológica y biogeográfica, la ubicación geográfica y su climatología. La Península Ibérica 
pertenece a la región Paleártica y su fauna de mamíferos terrestres es típicamente europea, con algunos elementos africanos originales. Dejemos fuera de este análisis a los murciélagos por su capacidad de volar e incluso de migrar a largas distancias en algunas especies, y a los Cetáceos por su capacidad de desplazamiento. El Estrecho de Gibraltar se abrió a finales del periodo Mesiniense (hace algo más de 5 millones de años), con lo que la conexión occidental entre Europa y el norte de África quedó interrumpida. La eficacia de esta barrera marina ha condicionado el poblamiento actual, siendo la mayoría de mamíferos típicamente centroeuropeos y de amplia distribución. Otras especies son propias del área mediterránea, en muchos casos endemismos ibéricos. Diversas especies de mamíferos africanos han sido introducidas en Iberia por el hombre hace varios siglos o incluso milenios, por ejemplo el erizo moruno, gineta, meloncillo, ratón moruno, etc.

Los mamíferos endémicos ibéricos son una gran proporción en nuestra fauna respecto a otras regiones europeas. En un sentido estricto, la liebre de piornal es el único mamífero endémico de la España peninsular, ya que se encuentra sólo en la Cordillera Cantábrica. El resto de endemismos son ibéricos, como por ejemplo la cabra montés, o bien con una pequeña área en Francia o Portugal para varias especies como el desmán ibérico, la rata de agua y los topillos pirenaico, mediterráneo y lusitano. El topo ibérico y la liebre ibérica ocupan casi toda la península, excepto el tercio nororiental, mientras que la musaraña ibérica se limita al noroeste. Por su parte el topillo de Cabrera está presente en la España Central y el Prepirineo, mientras que el lince ibérico, tal vez el felino más amenazado del planeta, ocupaba hasta hace pocas décadas buena parte de nuestra geografía, pero se encuentra hoy en día al borde de la extinción, habiendo desaparecido de Portugal. Esta elevada proporción de endemismos (cerca del $20 \%$ de las especies consideradas) es sensiblemente superior al encontrado en cualquier otra región de Europa. La explicación hay que buscarla en el papel de las penínsulas mediterráneas, y especialmente la ibérica, como refugio de fauna durante las últimas glaciaciones. En nuestro caso, además, hay que considerar la disposición de las cordilleras y grandes ríos, que actúan a modo de barreras más que de corredores, lo que favorece un mayor nivel de endemicidad. Este fenómeno no es exclusivo de los mamíferos, sino que también se da en otros grupos animales y vegetales.

En el primer atlas de los mamíferos terrestres de España (Palomo \& Gisbert, 2002) se citaron 106 especies, repartidas en 7 órdenes taxonómicos. Como sucede con los peces continentales, la aplicación de loas nuevas técnicas moleculares a los mamíferos ha supuesto cambios taxonómicos a nivel de grupos, especies y subespecies. Seguimos aquí la nomenclatura del "Atlas y libro rojo de los mamíferos terrestres de España” (Palomo, Gisbert \& Ruiz Olmo, 2007) que a su vez sigue la nomenclatura supraespecífica de "Mammal Species of the World: A Taxonomic and Geographic Referente" $3^{\mathrm{a}}$ ed. (Wilson \& Reeder, 2005). Esto implica numerosas novedades taxonómicas. Diversas cuestiones están en debate, lo que podría modificar en un futuro la 96 composición de la lista de especies españolas. 
En la actualidad (Palomo et al., 2007), se considera que los mamíferos terrestres españoles incluyen 107 especies, 94 en la Península Ibérica, 4 exclusivas de las Islas Canarias y 9 de distribución transfretana (es decir de los territorios españoles en el Norte de África; Ceuta, Melilla y diversos peñones e islotes). Delibes \& Gisbert (2002) aumentan esta cifra hasta 158 especies, considerando también a los Cetáceos, las especies introducidas, etc. Hay un orden exclusivamente marino, los Cetáceos, con 32 especies y 8 órdenes taxonómicos de grupos terrestres: 2 especies en los Erinaceomorfos y 14 en los Soricomorfos (antes Insectívoros), 31 especies de Quirópteros, 18 Carnívoros, 8 Artiodáctilos, 28 Roedores, 5 Lagomorfos y 1 Macroscélido.

La fauna europea de mamíferos es pobre, comparada con la tropical, a pesar de la variedad de hábitats apropiados para el grupo. En España se encontrarían entre 106 y 107 especies autóctonas terrestres, de las 264 citadas en Europa occidental; es decir aproximadamente el 38\% de las mismas. De las 42 familias de mamíferos descritas en el Paleártico, 21 están presentes en la Península Ibérica. Algunas especies son problemáticas, por hallarse sólo en la vertiente francesa de los Pirineos (el muscardino) o en el Peñón de Gibraltar (Macaco o mona de Berbería).

El Orden Cetáceos recoge 32 especies en las costas españolas. Incluye a los delfines y ballenas. Algunos son comunes en las cosatas como el delfín listado (Stenella coeruleoalbus), el delfín mular (Tursiops truncatus), el calderón (Globicephala melas), la marsopa (Phocoena phocoena), la orca (Orcinus orca) y el cachalote (Physeter catodon). Las Canarias, el estrecho de Gibraltar y el mar de Alborán son zonas excelentes para el creciente turismo de observación.

Aproximadamente 90 especies son mamíferos autóctonos de la España peninsular. Entre los Erinaceomorfos hay 2 especies de erizos, el europeo y el moruno. Dentro de los Soricomorfos, se incluyen las restantes 12 especies de insectívoros que incluyen dos especies de topos, el desmán ibérico, en peligro de extinción, y 9 musarañas, entre ellas el musgaño enano o musarañita, que es el mamífero más pequeño de Europa.

Los Murciélagos o Quirópteros son el orden mejor representado, con cerca de 30 especies diferentes: 4 murciélagos rinolofos (género Rhinolophus), 9 ratoneros (Myotis), 4 enanos (Pipistrellus), 3 nóctulos (Nyctalus), 3 orejudos (Plecotus), 1 de montaña (Hypsugo), 1 hortelano (Eptesicus), 1 de bosque (Barbastella), 1 murciélago de cueva (Miniopterus) y 1 rabudo (Tadarida). La mayor parte de nuestros murciélagos están amenazados por causas variadas (destrucción de refugios, alteración del hábitat; uso de insecticidas, etc.).

El grupo de los Carnívoros comprende 16 especies autóctonas, incluyendo algunas especies emblemáticas y/o muy amenazadas. Entre ellas grandes carnívoros como el lince ibérico, oso pardo, el lobo o la nutria. No debemos olvidar al grupo de 
las focas (Fócidos), hasta 6 especies, que visitan ocasionalmente nuestras costas, pero que ya no crían en ellas desde hace muchas décadas. La foca monje del Mediterráneo sería una especie prioritaria pues prácticamente ha desaparecido de las costas españolas, aunque criaba con regularidad hasta la primera mitad del s. XX en las costas mediterráneas y las Baleares.

Los Ungulados comprenden los mamíferos que tienen pezuñas y se dividen en los Artiodáctilos y los Perisodáctilos. No existen actualmente en España Perisodáctilos silvestres y entre las formas domesticadas están los caballos, burros, asnos y mulas. En los Artiodáctilos encontramos especies salvajes y domesticadas como los cerdos, cabras, ovejas y vacas. Las 6 especies silvestres (autóctonas) existentes son el jabalí, 2 cérvidos (ciervo, gamo), 1 capreólido (corzo), 2 bóvidos (rebeco y cabra montés). Todos ellos tienen gran interés cinegético, lo que condiciona claramente su distribución y abundancia.

El orden de los Roedores es el más abundante en especies a nivel mundial. Su alimentación es básicamente herbívora, aunque existen especies granívoras, frugívoras y forrajeras, y omnívoras. En España se incluyen 20 roedores autóctonos en la Península Ibérica, 4 especies transfretanas y 4 introducidas. Destaquemos a la ardilla roja (Sciurus vulgaris) como especie emblemática de las zonas forestales; 2 especies de lirones (género Glis; gris y careto), 8 topillos (6 Microtus, Clethrionomys, Chionomys, Micromys...), 2 ratas de agua (Arvicola), 5 especies de ratones (Apodemus, Mus) y dos de ratas (Rattus). El orden de los Lagomorfos incluye 3 especies de liebres (gén. Lepus) presentes en Iberia, y el conejo (Oryctolagus cuniculus), una especie clave por ser la presa fundamental en los ecosistemas mediterráneos para diversos depredadores muy amenazados como el lince ibérico o el águila imperial. Las enfermedades introducidas en esta especie, neumonía hemorrágica vírica y mixomatosis, han supuesto la práctica desaparición del conejo en numerosas zonas peninsulares, con el consiguiente declive de sus depredadores especializados.

\section{Las especies introducidas}

Diversas especies han sido introducidas en España en diversos momentos históricos, podemos citar a los gamos, ratón moruno, gineta, meloncillo, aunque la época de su llegada o introducción no es bien conocida. Otras especies, parecen haber llegado de Asia en la Edad Media como la rata gris (propagadora de la peste) o después de las guerras napoleónicas, como la rata negra. En cualquier caso, son especies que llevan en nuestro país el suficiente lapso de tiempo como para ser consideradas nativas o autóctonas. En cierto modo, la consideración de una especie como alóctona o invasora se basa en criterios exclusivamente de tipo temporal.

En ocasiones se conoce con detalle tanto la fecha como la vía de entrada; éste es 98 el caso de la ardilla moruna y del visón americano, cuyas poblaciones actuales proce- 
den de ejemplares escapados de cautividad. Otras, como la marmota, la rata almizclera o el coipú, han entrado a la península desde Francia, a través del País Vasco o por los Pirineos. En otras ocasiones las poblaciones foráneas son fruto de introducciones cinegéticas recientes llevadas a cabo por el ser humano, como en el caso del muflón y el arruí.

El visón americano (Neovison vison) es una especie invasora en expansión que está afectando muy negativamente a otras especies de vertebrados. Especie norteamericana introducida para su cría por para la industria peletera y semiacuática, puede encontrarse en las cercanías de cualquier medio ribereño. Las primeras poblaciones españolas proceden de una granja del Espinar (Segovia), la primera instalada en España y de la que escaparon los primeros ejemplares hacia 1958. Es una especie invasora en expansión. Se ha intentado en diversas zonas españolas, con poco éxito, limitar su abundancia, por sus efectos nocivos sobre el visón europeo y el turón especialmente.

La ardilla moruna (Atlantoxerus getulus) es una ardilla terrestre de origen norteafricano. En España habita la isla de Fuerteventura y se han citado individuos en Gran Canaria y Lanzarote. El impacto socioeconómico de la ardilla moruna en Fuerteventura parece escaso aunque los agricultores se quejan de los daños en los cultivos y en los muros. También se ha comentado la disminución de especies de caza menor como la perdiz, por consumo de sus huevos. No hay datos precisos que lo demuestre.

La marmota alpina (Marmota marmota) es originaria de los Alpes y los Montes Tatra. En la vertiente francesa de los Pirineos han sido introducidos ejemplares desde 1948 procedentes de los Alpes occidentales. Actualmente se encuentra en expansión en todo el Pirineo, desde Gerona a Navarra.

\section{Las especies emblemáticas y su estado de conservación}

Analizaremos el estado de conservación de los mamíferos terrestres españoles basándonos en el Catálogo nacional de especies amenazadas (CNEA) y en las categorías de la UICN, revisadas en el Atlas y Libro rojo del año 2007 (Palomo et al., 2007). Nos detendremos únicamente en las especies más amenazadas, en peligro crítico (CR) o en peligro de extinción EN.

La descripción de las categorías de la IUCN han cambiado notablemente entre el libro rojo de 1992 y el año 2006 (Palomo et al., 2007), pero en la siguiente tabla se observa que no ha habido cambios en las especies más amenazadas, que siguen estando muy amenazadas o han aumentado incluso a “En Peligro Crítico". Recordemos que estas categorías se refieren al territorio español, existiendo otras más generales a escala mundial cuando la especie tiene una distribución mayor. 


\begin{tabular}{|l|r|l|r|}
\hline \multicolumn{1}{|c|}{ Libro Rojo 2006 } & & \multicolumn{1}{|c|}{ Libro Rojo 1992 } & \\
\hline En peligro crítico (CR) & 3 & & 4 \\
\hline En peligro (EN) & 1 & En peligro (E) & 2 \\
\hline Vulnerable (VU) & 6 & Vulnerable (VU) & 5 \\
\hline Casi amenazadas (NT) & 5 & Rara (R) & 5 \\
\hline Datos insuficientes (DD) & 3 & Insuficientemente conocida (K) & 45 \\
\hline Preocupación menor (LC) & 43 & No amenazada (NA) & 5 \\
\hline No evaluadas (NE) & 15 & No evaluadas & 66 \\
\hline Especies totales & 76 & Especies totales & \\
\hline
\end{tabular}

Tres especies se encuentran En Peligro Crítico (CR), el lince ibérico, el oso y la foca monje. Una especie En Peligro de extinción (EN), el visón europeo.

El lince ibérico (Lynx pardinus) está en Peligro Crítico de extinción. Como especie exclusiva de España, ya que parece haberse extinguido en Portugal, existe una enorme responsabilidad española de salvar al lince ibérico, considerado el felino más amenazado del mundo. Es importante recuperar su hábitat y especialmente las poblaciones de conejos con el fin de plantear la reintroducción futura en zonas donde se extinguió recientemente. La situación parece haber mejorado por la estabilización y cría en cautividad.

El lince ibérico es un endemismo de la Península Ibérica y originalmente se encontraba en las zonas de clima mediterráneo. A lo largo del siglo XX desaparece de la mayor parte de la Península, con múltiples episodios de fragmentación poblacional y extinción local. En 1988 sólo se identificaron 48 núcleos de presencia estable agrupados en nueve poblaciones con una estimación para España de 1.136 linces de más de un año, repartidos en 9 subpoblaciones muy fragmentadas y aisladas entre sí, calculándose que quedaban alrededor de 350 hembras reproductoras.

Entre 1999 y 2002 se estimó que en España había 160 linces de más de un año distribuidos en un área de 2.200 km², repartidos en dos subpoblaciones en Andalucía, una en Doñana (con 8 hembras reproductoras) y otra en Sierra Morena Oriental (1823 hembras reproductoras). Por lo tanto, sólo en 16 años (1985-2001), el área de ocupación de la especie ha disminuido un $87 \%$, el área con reproducción un 93\%, el número de hembras reproductoras en más de un $90 \%$ y la cantidad de linces de más de un año de edad en un $86 \%$. En 2005 se ha estimado que en Andalucía quedan entre 83 y 167 linces de más de un año de edad, entre 32 a 42 en Doñana, y de 51 a 125 en Sierra Morena. De 2001 a 2005 el declive parece haberse desacelerado, observándose incluso algunos signos de estabilización, al menos en la población de Sierra Morena.

El oso pardo (Ursus arctos) está también en Peligro Crítico. Antiguamente ocupaba toda la Península Ibérica, pero desde el s. XVIII sólo quedan dos núcleos, la zona 
Galaico-Cantábrica y la zona Pirenaica. La población pirenaica podría tener unos 20 ejemplares. En el Pirineo se han introducido ejemplares procedentes de Eslovenia para reforzar la población, aunque con escaso éxito por la persecución humana y el rechazo de los ganaderos de la zona francesa y española.

En la zona Galaico-Cantábrica el número de osos ha aumentado significativamente desde mediados de los 90, pero no hay prácticamente contactos entre las dos subpoblaciones. En la Cordillera Cantábrica hay unos 105-130 osos en dos núcleos aparentemente aislados: el occidental (unos 80-100 ejemplares) y el oriental (25-30 osos). Las amenazas a estas poblaciones se deben a la ocupación humana de las montañas, fragmentación, infraestructuras de carreteras, turísticas, estaciones de esquí, urbanizaciones, etc. No debemos olvidar que esta especie convive mal con la excesiva presencia humana en su hábitat. La proyectada estación de esquí de San Glorio en León podría llevar a la extinción a la población oriental de osos de la Cordillera Cantábrica. Este proyecto supone un incumplimiento de la Directiva de Hábitat y de la normativa que protege al oso pardo en España.

Un mamífero marino se encuentra también en peligro crítico $\mathrm{CR}$, la foca monje (Monachus monachus), que históricamente se distribuía a lo largo de las costas del Mediterráneo y el Mar Negro, y en el Atlántico a lo largo de la costa africana desde el Estrecho de Gibraltar hasta Mauritania, islas Desertas en Madeira (Portugal) y otras áreas del Mediterráneo. En España existen citas de capturas y observaciones durante el siglo XX en casi toda la costa del Mediterráneo, Baleares, Canarias e islas Chafarinas. Aunque se ha extinguido de la mayor parte de las costas y aguas españolas, la especie todavía frecuenta las Islas Chafarinas (Melilla), donde se ven ejemplares que forman parte de la pequeña población de la costa de Marruecos y Argelia.

El visón europeo (Mustela lutreola) se encuentra En Peligro de extinción (EN) en España. Hasta principios del siglo XIX ocupaba toda Europa central y septentrional y desde entonces se ha extinguido en más de 20 países europeos. La población europea occidental se restringe a una pequeña área en el suroeste de Francia y norte de España, que en estos momentos se encuentran separadas. No existen citas anteriores al siglo XIX en Francia y la especie no era conocida en España antes de 1950, por lo que la población ibérica procedería de la expansión natural que habría comenzado a principios del siglo XX.

En España está presente en Navarra, La Rioja, País Vasco y Castilla-León (NE de Burgos y $\mathrm{N}$ de Soria). Su tendencia poblacional es variable, con cuencas donde se ha expandido y otras de donde ha desaparecido, pero la especie sigue amenazada por la rápida expansión del introducido visón americano, un fenómeno que es ya irreversible. La población ha descendido desde unos 1.000 individuos a principios de los 90 hasta unos 500 ejemplares adultos en 2000-2001. Se prevé una reducción mayor en el futuro cuando las poblaciones de visón americano invadan las áreas del visón europeo. Existe en la actualidad un proyecto LIFE para la conservación del visón europeo que incluye la eliminación del visón americano en las zonas de contacto. 
Otras especies han incrementado su categoría de amenaza, subiendo a la categoría de Vulnerables. El conejo de monte (Oryctolagus cuniculus) es un endemismo ibérico, aunque con distribución mundial en la actualidad dada su caza y dispersión por el hombre desde épocas remotas. Suele ser más habitual en zonas mediterráneas, con coberturas de matorral cercanas al 40\%, y zonas de pastizales o cultivo herbáceo próximos. La severa disminución desde finales de los 80 a causa de la neumonía y la enfermedad hemorrágica (un 30\% de disminución en la última década) le ha llevado a la lista de especies amenazadas.

Las otras tres especies que muestran una disminución alarmante son micromamíferos poco conspícuos, dos de los cuales viven en medios acuáticos (la rata de agua y el desmán) mientras que el topillo de Cabrera vive sobre todo en prados húmedos. Los tres son endemismos o subendemismos (cuasiendemismos) ibéricos, restringidos a la Península Ibérica y a unas pocas áreas limítrofes. Estos micromamíferos pueden servir como bandera para recordarnos las necesidades de las pequeñas especies anónimas, que suscitan menores esfuerzos de conservación que los mamíferos más carismáticos. En la actualidad, la destrucción masiva de hábitat empieza a afectar a especies que en otro tiempo fueron comunes.

El desmán ibérico o topo de agua (Galemys pyrenaicus) es un casi-endemismo ibérico presente desde la vertiente francesa de los Pirineos hasta la mitad septentrional de Portugal, ocupando áreas del interior de la Península, Es un curioso "topo" acuático con un largo hocico provisto de pelos especializados que utiliza como un órgano táctil para detectar a sus presas mientras bucea. Vive en galerías al borde de ríos y arroyos de fuerte pendiente, siempre en aguas oxigenadas y limpias de corriente constante. Su presencia está ligada principalmente de la pendiente de los ríos, su profundidad (pequeña o moderada) y la velocidad de corriente, así como a la abundancia de invertebrados acuáticos. Se considera En peligro de extinción (Palomo et al, 2007).

El topillo de Cabrera (Microtus cabrerae) es un endemismo ibérico considerado Vulnerable. Habita zonas mediterráneas con vegetación herbácea abundante y verde a lo largo de todo el año, condicionada por tanto a zonas húmedas de montaña o de suelos húmedos, en prados cerca de arroyos, junqueras, etc.

La rata de agua (Arvicola sapidus) se distribuye por toda la Península Ibérica y gran parte de Francia. Es un roedor semiacuático ligado a los cursos de agua estable con abundante vegetación en sus márgenes. A veces se puede encontrar lejos de los cursos de agua, en prados húmedos, charcas secas o zonas turbosas. Se la considera Vulnerable según la UICN ya que parece existir una fuerte regresión en su distribución, superior al 30\% debida a la reducción o pérdida de calidad de hábitat y al efecto de taxones introducidos, como por ejemplo el visón americano.

La musaraña canaria (Crocidura canariensis) es otra especie Vulnerable según las categorías UICN (2006). Endémica de las Canarias, habita en las islas de Fuerteventu- 
ra y Lanzarote y en los islotes de Lobos y Montaña Clara. Su área de distribución es muy pequeña (menor de $2.500 \mathrm{~km}^{2}$ ). La urbanización y la desertificación causan la disminución del hábitat disponible. Atendiendo estrictamente a los criterios de la UICN, debería estar en peligro como EN B1, pero la Insectivore Red List Authority la incluyó en 2004 en la categoría VU.

Los Quirópteros o murciélagos tienen un papel beneficioso en el control de poblaciones de Insectos considerados perjudiciales para la agricultura o la salud. Son vitales para el equilibrio natural y buenos bioindicadores de la calidad del hábitat. Son un grupo muy numeroso, con cerca de 30 especies en territorio español. Casi todas las especies de Quirópteros se consideran amenazados y están en las categorías de EN Peligro (EN), Vulnerables (VU) o Casi amenazados (NT). En peligro podemos citar al rinolofo mediano de herradura y al orejudo canario. Como especies Vulnerables se encuentran el mediterráneo de herradura, ratonero grande, ratonero mediano, ratonero pardo, ratonero forestal, ratonero patudo, nóctulo mediano, nóctulo grande y murciélago de cueva. Son especies casi amenazadas (NT) el rinolofo o murciélago grande de herradura, pequeño de herradura, ratonero bigotudo, ratonero gris, pipistrello de Nathusius, pipistrello de Madeira, murciélago montañero, nóctulo pequeño, barbastela, orejudo dorado, orejudo gris y murciélago rabudo

Dentro de los Carnívoros, algunos se hallan en la categoría UICN Casi amenazado (NT), el turón y el gato montés. El turón (Mustela putorius) se encuentra en toda la Península Ibérica, pero no en Baleares o Canarias, aunque es escaso en las mesetas centrales y en la zona oriental. Parece estar en declive por la persecución humana ilegal (está protegido como todos los Carnívoros, sólo el zorro es especie cinegética), la pérdida de hábitat y la rarificación del conejo, una de sus presas habituales. El Turón podría ser afectado negativamente por la competencia causada por el visón americano, especialmente en las zonas cercanas a ríos y arroyos de Guadarrama.

El gato montés (Felis silvestris) ocupaba toda la Península, pero no las Baleares, Canarias o el norte de África. Su distribución actual se ha reducido y está centrada sobre todo en las zonas montañosas. Parece estar en declive por la hibridación genética y la transmisión de enfermedades de gatos domésticos o asilvestrados, los procesos de fragmentación, la pérdida de calidad de los hábitats naturales y la mortalidad directa por confusión durante la caza (no es especie cinegética).

Dos especies incluidas en la categoría Vulnerable en 1992 se encuentran en la actualidad en proceso de recuperación, la nutria y el lobo. El lobo (Canis lupus) es una especie emblemática en España. Ocupó toda la Península, pero su área de distribución se redujo fuertemente por la persecución humana y las armas de fuego durante los siglos XIX y XX. Está ausente de los archipiélagos balear y canario, y de los territorios del norte de África. Desde su máximo declive en la década de 1960-70, el lobo se está recuperando. En las últimas décadas ha recolonizado áreas muy humanizadas e incluso zonas agrícolas deforestadas. En España ocupa actualmente un área continua en el cuadrante noroccidental; en la mayor parte de Galicia y norte de Castilla y León, 
gran parte de Asturias y Cantabria y pequeñas porciones de Álava, Vizcaya, La Rioja y Guadalajara. En Andalucía (Sierra Morena) queda una pequeña población relicta y aislada.

En España se le considera actualmente Casi Amenazado (NT). Se calcula unas 250 manadas conocidas en España, lo que representa unos 2.000 individuos, de los que 1.000 serían ejemplares maduros. La población española es contigua a la portuguesa, que consta de 51 a 63 manadas. Los daños al ganado y la consiguiente hostilidad de los ganaderos constituyen su principal problema de conservación. Existe una Estrategia nacional para la conservación y la gestión del lobo en España, aprobada por la Comisión nacional de conservación de la naturaleza en 2004. La especie es enormemente adaptable y si no es perseguido ilegalmente, puede vivir en áreas densamente pobladas alimentándose de carroñas de animales domésticos.

Más optimista aún es el caso de la nutria (Lutra lutra), que se ha recuperado en los tres sondeos realizados por la SECEM desde el año 1984, por lo que se ha decidido considerarla como No Amenazada, debido a la protección legal directa y a la reducción de la contaminación de los ríos. Ocupaba toda la Península Ibérica, excepto tal vez la provincia de Almería. Nunca ha habitado las Baleares ni las Canarias. En la Península sufrió un importante proceso de regresión desde 1950 hasta mediados de los 80, desapareciendo especialmente de la mitad este, en los ríos de tipo mediterráneo. La nutria también desapareció de las zonas industrializadas, de las zonas más turísticas, de las grandes planicies agrícolas (con agricultura intensiva) y del entorno de las grandes ciudades. A partir de mediados de los 80 , la especie ha iniciado un lento proceso de recuperación en determinadas zonas, especialmente en el área pirenaica y zonas periféricas, en la zona central, en Andalucía occidental, y en algunos sectores de Castilla y León.

\section{Las especies de caza mayor}

La cabra montés (Capra pyrenaica) es una especie emblemática tanto desde el punto de vista de fauna salvaje autóctona de las montañas ibéricas, como por su enorme valor cinegético. Se la considera casi amenazada a nivel nacional, al menos algunas de sus poblaciones. Es endémica de la Península Ibérica. De las cuatro subespecies descritas por Ángel Cabrera en 1911 (puestas en duda por algunos autores), existen en la actualidad dos, al haberse extinguido C. p. Iusitanica, de Galicia y Portugal (a finales del siglo XIX) y C. p. pyrenaica (el bucardo pirenaico, cuyo último individuo murió en 1998). La subespecie C. p. victoriae se distribuye por el Sistema Central (Gredos) y otras zonas donde se ha reintroducido, La subespecie C. p. hispanica ocupa la zona mediterránea y Sierra Morena. En Sierra Nevada se ha descrito por Wyrwoll en 1999 la subespecie C.p nowaki o nowakiae y cuyo estatus es dudoso.

La población estimada en la Península es de unos 50.000 ejemplares distribuidos en más de 27 núcleos, entre los que destacan Sierra Nevada (16.000 ejemplares), Gre- 
dos (8.000), Maestrazgo (7.000), Serranía de Ronda y Sierras de Grazalema (4.000), Cazorla (2.500), Sierra Tejeda y Almijara (2.500), Sierras de Antequera (2.000), Sierra Morena (2.000) y Muela de Cortes (1.500). La fragmentación de las poblaciones y especialmente la baja variabilidad genética les confiere cierto grado de amenaza. Las epizootias también han causado mortalidad masiva en algunas poblaciones.

El jabalí (Sus scrofa) es una especie cinegética de caza mayor. Ampliamente distribuido por la Península y en expansión, ocupa hábitats forestales, marismas, agrosistemas y periferias urbanas. En las últimas décadas ha experimentado un fuerte incremento demográfico atribuible a cambios socioeconómicos que han comportado el progresivo despoblamiento rural y el abandono de actividades tradicionales que han provocado un importante aumento de la superficie de bosque y matorral y el incremento de la agricultura intensiva. La expansión de su población genera conflictos económicos y sociales (daños en cultivos, colisiones de vehículos). No requiere actualmente medidas de conservación, sino más bien de técnicas de control poblacional.

El venado o ciervo rojo (Cervus elaphus) se extiende por casi todo el territorio peninsular, excepto la parte más occidental de Galicia y la costa de Levante. No se encuentra en Baleares y Canarias o en los territorios españoles del norte de África. Es una especie cinegética de caza mayor. Las estadísticas hablan de más de 70.000 cazados al año de ambos sexos. La explotación de la caza mayor, con el ciervo como pieza fundamental, es un importante recurso económico, fundamentalmente en Extremadura, Castilla-La Mancha y Andalucía.

El gamo (Dama dama) es una especie de distribución original por la Europa mediterránea y Oriente próximo. Fue introducida en Iberia, aunque no se sabe exactamente cuándo (se habla de los romanos pero podría haber sido por los reyes españoles para cazaderos reales). A finales del siglo XIX vivía en estado salvaje en Sierra Morena, Cuenca del Tajo y Montes de Toledo y otros cazaderos reales. Fue introducido en Doñana a principios del siglo XX. Actualmente se halla en numerosas fincas y cotos de caza mayor con fines cinegéticos y de recreo.

El corzo (Capreolus capreolus) es una especie cinegética eminentemente forestal, que prefiere los bosques con matorral diverso y zonas de pastizal cercanas (puede llegar a explotar medios agrícolas). Sufrió un drástico descenso en sus poblaciones en la primera mitad del siglo XX y su recuperación se vio facilitada por el despoblamiento rural y regularización de la especie. En España se distribuye actualmente por toda la zona norte, desde Cataluña a Galicia, aunque es abundante en zonas forestales del Sistema Central e Ibérico. Se ha revalorizado como trofeo de caza mayor al aumentar sus poblaciones. Su expansión provoca problemas de gestión relacionados con daños a la agricultura, aprovechamientos forestales y atropellos.

El rebeco (Rupicapra pyrenaica) es un bóvido, a diferencia del ciervo, corzo o gamo. En la Península Ibérica existen dos núcleos poblacionales correspondientes a dos sub- 
especies: cantábrica y pirenaica, que algunos diferencian como especies. Las reservas de caza existentes en la Cordillera Cantábrica y Pirineos han permitido una notable recuperación poblacional. No poseen factores de amenaza particulares. Un nivel de caza razonable es suficiente para asegurar la conservación de sus poblaciones.

El muflón (Ovis aries $=0$. gmelini $)$ es otra de las especies introducidas para la caza mayor. Originario de Córcega, el muflón se considera el ancestro de las ovejas y de todas las poblaciones que existen en la actualidad en España. Los primeros ejemplares se introdujeron en España en la Serranía de Cuenca y posteriormente en la Sierra de Cazorla en 1954. De estos núcleos, se han extendido por toda el área mediterránea de la Península Ibérica, tanto en reservas de caza como en cotos de casi todas las provincias, llegando en los años 70 incluso al Parque Nacional del Teide. Está sin embargo ausente de Baleares y norte de África. Es una especie muy apreciada para la caza mayor, por lo que se está extendiendo con el consiguiente peligro de competencia con otros ungulados silvestres.

El Arruí o carnero de Berbería (Ammotragus lervia) es otra de las especies introducidas para la caza mayor. Procede de las zonas escarpadas y montañosas de las regiones semidesérticas del norte de África. En España se introdujo en 1970 en el Parque Natural de Sierra Espuña, Murcia, origen de la expansión posterior a diversos puntos del sur español y en la canaria isla de La Palma, donde vive incluso en el parque nacional de la Caldera de Taburiente, en la que causa importantes daños. Especie de gran interés cinegético dado el valor de sus trofeos. En España el crecimiento de las poblaciones es notable, lo que podría hacer peligrar a los ungulados autóctonos, en particular a la cabra montés, su competidor más directo por el hábitat.

\section{REFERENCIAS BIBLIOGRÁFICAS}

Araujo, R., 2006. Margaritifera margaritifera (Linnaeus, 1758). En Verdú y Galante (eds.). Libro Rojo de los Invertebrados de España. Dirección General para la Biodiversidad. Ministerio de Medio Ambiente. Madrid.

Arconada B., Ramos, M.A., y Rolán, E., 2006. Belgrandiella edmundi Boeters, 1984. Belgrandiella galaica Boeters y Rolán, 1988. Spathogyna fezi (Altimira, 1960). Tarraconia rolani Ramos, Arconada y Moreno, 2000. En Verdú y Galante (eds.). Libro Rojo de los Invertebrados de España. Dirección General para la Biodiversidad. Ministerio de Medio Ambiente. Madrid.

Asensio, B. (coord.) 2002. La naturaleza de España. Organismo Autónomo Parques Nacionales. Ministerio de Medio Ambiente, Madrid.381 págs.

Barbadillo, L. J., Lacomba, J.I., Pérez-Mellado, V., Sancho, V., \& López-Jurado, L. F. 1999. Anfibios y Reptiles de la Península Ibérica, Baleares y Canarias. Ed. Geoplaneta, Barcelona. 419 pp.

Barbadillo, L.J. 2002. Anfibios y reptiles. Págs 226-235. En Asensio, B. (coord.) 2002. La naturaleza de España. Organismo Autónomo Parques Nacionales. Ministerio de 106 Medio Ambiente, Madrid.381 págs. 
Blanco J.C. and González J.L. 1992 Libro rojo de los Vertebrados de España. ICONA, Madrid.

Blanco, J.C.(coord) 1998. Guía de campo de los mamíferos de España Vols. I y II. Planeta. Barcelona.

CBD (Convention on Biological Diversity) Secretariat, 2002. First and second national reports on biodiversity. http://www.biodiv.org/world/reports.asp

Costello, M.K., Emblow, C., y White, R. (eds.) 2001. European Register of Marine Species. A check-list of marine species in Europe and bibliography of guides to their identification. Patrimonies naturels, 50, Museum National d'Histoire Naturelle. Paris. 463 pp.

De Juana, E. 2002. Aves. Págs 236-253. En Asensio, B. (coord.) 2002. La naturaleza de España. Organismo Autónomo Parques Nacionales. Ministerio de Medio Ambiente, Madrid.381 págs.

De Juana, J. \& Varela 2001. Guía de las aves de España. SEO Birdlife. Ed. Lynx, Barcelona.

De Sostoa, A. 2002. Las Comunidades de Peces en las Cuencas Mediterráneas: Caracterización y Problemática. En: Atlas y Libro Rojo de los Peces Continentales de España (ed. Doadrio, I.), pp. 51-56, CSIC y Ministerio del Medio Ambiente, $2^{\text {a Edi- }}$ ción, Madrid, España.

Delibes, M. \& Gisbert, J. 2002. Mamíferos. Págs 254-269. En Asensio, B. (coord.) 2002. La naturaleza de España. Organismo Autónomo Parques Nacionales. Ministerio de Medio Ambiente, Madrid.381 págs.

Doadrio, I. \& Elvira, B. 2002. Peces continentales. Págs 216-225. En Asensio, B. (coord.) 2002. La naturaleza de España. Organismo Autónomo Parques Nacionales. Ministerio de Medio Ambiente, Madrid.381 págs.

Doadrio, I. (ed.).2002. Atlas y libro rojo de los peces continentales de España. Dirección General de Conservación de la Naturaleza (Ministerio de Medio Ambiente). Madrid. 364 pp.

Doadrio, I. 2002. Origen y Evolución de la Ictiofauna Continental Española. En: Atlas y Libro Rojo de los Peces Continentales de España (ed. Doadrio, I.), pp. 20-34, CSIC y Ministerio del Medio Ambiente, $2^{\text {a }}$ Edición, Madrid, España.

Doadrio, I., Elvira, B. \& Bernat, Y. (eds.) 1991. Peces continentales españoles. Inventario y clasificación de zonas fluviales. Colección Técnica. ICONA-CSIC, Ministerio de Agricultura, Pesca y Alimentación, Madrid. Colección Técnica. ICONA-CSIC, MAPA, Madrid, $221 \mathrm{pp}$.

EEA (European Environment Agency), 1 (EEA), 2002a. The European Biodiversity Monitoring and Indicators Framework (EBMI-F). http://www.strategyguide.org/ ebmf.html

EEA (European Environment Agency), 1995. Europe's Environment. The Dobris Assessment.Copenhagen.

EEA (European Environment Agency), 2002b. Report on Europe's Biodiversity. European Topic Centre on Nature Protection and Biodiversity (EEA-ETC/NPB), $2002 a$. NATURA 2000 database.

Elvira \& Almodóvar, 2008 Se describen nuevas especies de peces continentales ibéricos. Trofeo Pesca, 159: 102-103. 
Elvira, B. \& Almodóvar A. 2001. Freshwater fish introductions in Spain: facts and figures at the beginning of the 21st century. Journal of Fish Biology, 59 (Suppl. A): 323-331.

Elvira, B. 1995. Native and exotic freshwater fishes in Spanish river basins. Freshwater Biology, 33: 103-108.

Elvira, B. 1996. Endangered freshwater fish of Spain. In Conservation of Endangered Freshwater Fish in Europe (Kirchhofer, A. \& Hefti, D., eds.): 55-61. Basel: Birkhäuser Verlag.

Elvira, B. 1997. El declive de los peces fluviales en España. Ecosistemas, 27: 66-71.

Elvira, B. 1997. Impacto y control de los peces exóticos introducidos en España. En: Conservación, recuperación y gestión de la ictiofauna continental ibérica, (Granado-Lorencio, C. ed.): 139-151. Sevilla. Publicaciones de la Estación de Ecología Acuática.

Galante, E., y Verdú, J. R. 2000. Los Artrópodos de la “Directiva Hábitat” en España. Organismo Autónomo de Parques Nacionales (Ministerio de Medio Ambiente), Serie Técnica. Madrid. 186 pp.

García-París, M.; Montori, A. \& Herrero, P. 2004. Amphibia, Lissamphibia. En: Fauna Ibérica, vol. 24. Ramos, M.A. et al. (eds). Museo Nacional de Ciencias Naturales. CSIC. Madrid. 640 pp.

Granado, C. 2002. Ecología de Peces. Secretariado de Publicaciones, Universidad de Sevilla, $353 \mathrm{pp}$.

Groombridge, B. 1992a. Higher vertebrates. In: Groombridge B (ed) Global Biodiversity: Status of the Earth's Living Resources, pp 136-146. Chapman and Hall, London

Groombridge, B 1992b. Threatened species. In: Groombridge B (ed) Global Biodiversity: Status of the Earth's Living Resources, pp 234-247. Chapman and Hall, London

Hammond, PM 1992. Species inventory. In: Groombridge B (ed) Global Biodiversity: Status of the Earth's Living Resources, pp 17-39. Chapman and Hall, London

Heywood, V.H. \& Watson, R.T., 1995. Global Biodiversity Assessment. UNEP. Cambridge University Press. Cambridge.

Ibáñez, M., y Alonso, M.R., 2006. Napaeus isletae Groh e Ibáñez, 1992. Sculptiferussacia clausiliaeformis Alonso e Ibáñez, 1992. Hemicycla paeteliana (Shuttleworth, in Pfeiffer, 1859). Hemicycla plicaria (Lamarck, 1816). Hemicycla saulcyi (d'Orbigny, 1839). Canariella eutropis (Shuttleworth, 1860). En Verdú y Galante (eds.). Libro Rojo de los Invertebrados de España. Dirección General para la Biodiversidad. Ministerio de Medio Ambiente. Madrid.

Madroño, A.; González, C., \& Atienza, J.C. (eds.) 2004.: Libro Rojo de las aves de España. Ministerio de Medio Ambiente-Sociedad Española de Ornitología. Madrid, $452 \mathrm{pp}$.

Márquez, R., \& Lizana, M. 2002. Conservación de los Anfibios y Reptiles españoles, Cap. IV, pp: 345-383. En Pleguezuelos, J.M.; Márquez, R. y Lizana, M. (eds.) (2002). Atlas y libro rojo de los anfibios y reptiles de España. Dirección general de Conservación de la Naturaleza (MMA)-Asociación Herpetológica Española, 584 108 pp. Madrid. 
Martí, R., \& Del Moral J. C. (eds.) 2003. Atlas de las Aves reproductoras de España. Dir. Gral. de Conservación de la Naturaleza-SEO, Madrid, 733 pp.

Martínez-Ortí, A., Robles, F., Gómez, B., y Pujante, A.M., 2006 a. Melanopsis penchinati Bourguignat, 1868. En Verdú y Galante (eds.). Libro Rojo de los Invertebrados de España. Dirección General para la Biodiversidad. Ministerio de Medio Ambiente. Madrid.

Martínez-Ortí, A., Robles, F., Gómez, B., Bunje, P., y Pujante, A.M., 2006 b. Theodoxus boeticus (Lamarck, 1822). Theodoxus valentinus (Graells, 1846). En Verdú y Galante (eds.). Libro Rojo de los Invertebrados de España. Dirección General para la Biodiversidad. Ministerio de Medio Ambiente. Madrid.

May, R., 2005. Número de especies que habitan la Tierra En En Temas Investigación y Ciencia: Monográfico 35, Biodiversidad.

Meffe, G. K., Carroll, C.R. \& al. (1997): Principles of Conservation Biology. Sinauer Ass., INC.

MIMAM (Ministerio de Medio Ambiente) 2004. Catálogo Nacional de Especies Amenazadas. Listado de taxones por categorías de amenaza (agosto 2004). Dirección General de Conservación de la Naturaleza. Ministerio de Medio Ambiente. Madrid.

Ministerio de Medio Ambiente 1999. Estrategia nacional para la conservación y el uso sostenible de la diversidad biológica. Ministerio de Medio Ambiente, Madrid.

MMARM (2009). Cuarto informe nacional sobre la diversidad biológica. Ministerio de medio ambiente, y medio rural y marino. Informe inédito Madrid.

Moro, L., Martín, J.L., Garrido, M.J., e Izquierdo, I. (eds.). 2003. Lista de especies marinas de Canarias (algas, hongos, plantas y animales). Consejería de Política Territorial y Medio Ambiente del Gobierno de Canarias. La Laguna, Tenerife. 219 pp.

Myers, N., R. A. Mittermeier, C. G. Mittermeier, G. A. B. da Fonseca \& J. Kent. Biodiversity hotspots for conservation priorities. Nature, 403, 853-858.

Humphries, C. and Vane-Wright, R.I. (eds.) Systematics and Conservation Evaluation, pp 289-307. Clarendon Press, Oxford.

Oosterbroek, P. 1994. Biodiversity of the Mediterranean region. In: Forey PL, Humphries C3 and Vane-Wright RI (eds) Systematics and Conservation Evaluation, pp 289-307. Clarendon Press, Oxford.

Palomo, L.J.; Gisbert, J., \& Blanco, J.C. 2007. Atlas y libro rojo de los mamíferos terrestres de España. Atlas de los mamíferos terrestres de España, $2^{a}$ ed. Ministerio de Medio Ambiente, Madrid.

Pimm, S. \& Jenkins, C. 2005. Conservación de la biodiversidad. En Temas Investigación y Ciencia: Monográfico 35 Biodiversidad.

Pineda, F. D., De Miguel, J. M. Casado, M. A., y J. Montalvo (eds.). La diversidad biológica de España. Pearson Ed. Prentice Hall.

Pleguezuelos, J.M., \& Villafranca, C. 1997. Distribución altitudinal de la herpetofauna ibérica. En: Distribución y Biogeografía de los Anfibios y Reptiles en España y Portugal. Pleguezuelos, J.M. (Ed.). Monografías de Herpetología, vol. 3. Asociación Herpetológica Española y Universidad de Granada. Granada: 321-341.

Pleguezuelos, J.M., \& Villafranca, C. 1997. Distribución altitudinal de la herpetofauna ibérica. En: Distribución y Biogeografía de los Anfibios y Reptiles en 
España y Portugal. Pleguezuelos, J.M. (Ed.). Monografías de Herpetología, vol. 3. Asociación Herpetológica Española y Universidad de Granada. Granada: 321-341.

Pleguezuelos, J.M. 2002. Las especies introducidas de anfibios y reptiles. pp: 501-532. En Pleguezuelos, J.M.; Márquez, R. y Lizana, M. (eds.) (2002): Atlas y libro rojo de los anfibios y reptiles de España. Dirección General de Conservación de la Naturaleza (MMA)-Asociación Herpetológica Española, 584 pp. Madrid.

Pleguezuelos, J.M., Márquez, R., \& Lizana, M., (eds.) 2002. Atlas y Libro Rojo de los Anfibios y Reptiles de España. Dir. Gral. de Conservación de la Naturaleza-AHE (2 ${ }^{\mathrm{a}}$ impresión), Madrid, 584pp.

Primack, R. B. 1998. Essentials of Conservation Biology. Sinauer Associates.

Primack, R. B., \& Ros, J. 2002: Introducción a la biología de la conservación. Ed. Ariel, Barcelona.

Purroy, F.J. 2003. Guía de los mamíferos de España: Península, Baleares y Canarias. Ed. Lynx. 165 páginas.

Purroy, F. J. (coord.). (1997): Atlas de las Aves de España (1975-1995). SEO/BirdLife. Lynx Edicions. Barcelona, 583 pp.

Ramos, M. A., Lobo, J. M., y M. Esteban. 2002. Riqueza faunística de la península lbérica e islas Baleares. El Proyecto 'Fauna Ibérica’. Pp.197-207. En: Pineda, F. D., de Miguel, J. M. Casado, M. A. y J. Montalvo (eds.). La diversidad biológica de Espaก̃a.

Ramos, M.A. 1995. Biodiversidad: Fauna Ibérica. Política Científica, 44: 35-38.

Ramos, M.A., Bragado, D., y Fernández, J. 2001. Los invertebrados no insectos de la “Directiva Hábitat" en España. Organismo Autónomo de Parques Nacionales (Ministerio de Medio Ambiente). Serie Técnica. Madrid. 186 pp.

Ramos, M.A., Lobo, J.M., y Esteban, M. 2002. Riqueza faunística de la península Ibérica e islas Baleares. El proyecto ‘Fauna Ibérica’, pp. 197-207. En La Diversidad Biológica de España, Pineda, De Miguel, Casado y Montalvo (eds.), 2002. Prentice Hall, Madrid, 412 pp.

Rosas, G., Ramos, M.A., y García-Valdecasas, A. 1992. Invertebrados españoles protegidos por Convenios Internacionales. ICONA. Madrid. 250 pp.

Salvador, A. (coord.) 1998. Reptiles. Fauna Ibérica. Vol. 10. Museo Nacional de Ciencias Naturales. Madrid.

Salvador, A., \& García-París, M. 2001. Anfibios españoles. Canseco-Esfagnos, Ed., Talavera de la Reina. $269 \mathrm{pp}$.

Salvador, A., \& Pleguezuelos, J. M. 2002. Reptiles españoles. Canseco-Esfagnos, Ed., Talavera de la Reina. 493 pp.

Seo/Birdlife 2001. Tendencias de las poblaciones de aves comunes en España (19962000). SEO/BirdLife, Madrid.

Tellería, J.L. 2002. Vertebrados amenazados. pags. 331-338. En: Pineda, F. D., de Miguel, J. M. Casado, M. A. y J. Montalvo (eds.). La diversidad biológica de España.

Templado, J. 2001. La diversidad marina y su conservación. Pp.: 207-224. En: Marcos, C, García Charton, J. A. y Pérez Ruzafa, A. (ed.). Gestión y ordenación del medio 110 ambiente natural. Universidad de Murcia. 
Templado, J., Calvo, M., Garvía, M., Luque, A.A., Maldonado, M., y Moro, L. 2004. Guía de los invertebrados y peces marinos protegidos por la legislación nacional e internacional. Naturaleza y Parques Nacionales, Serie Técnica, Ministerio de Medio Ambiente. Madrid. 263 pp.

Templado, J. 2006. Estado actual de conocimientos sobre la diversidad marina en España y sus perspectivas. En: Conservación de La biodiversidad y explotación sostenible del medio marino (A. Ocaña y P.M. Sánchez Castillo, Eds.). Centro Mediterráneo, Universidad de Granada y Sociedad Granatense de Historia Natural, Granada, pp. 75-88.

Tucker G. M., \& Heath M.F. (1994): Birds in Europe: their conservation status. Birdlife Conservation Series, 3. Birdlife International. Cambridge.

UICN 2006. Categorías y Criterios de las Listas Rojas de la UICN: Comisión de Supervivencia de Especies de la UICN. UICN, Gland, Suiza.

UNEP-WCMC (World Conservation Centre) 2002. World Atlas of Biodiversity. <Mhttp:// www.unep-wcmc.org/>

Verdú, J.R., y Galante, E. (eds.), 2006. Libro Rojo de los Invertebrados de España. Dirección General para la Biodiversidad. Ministerio de Medio Ambiente. Madrid. 412 pp.

Verdú, J.R., y Galante, E. (eds.). 2006. Libro rojo de los invertebrados de España. Dirección General para la Biodiversidad, Ministerio de Medio Ambiente, Madrid. $411 \mathrm{pp}$.

Wilson, E.O. (2005). La biodiversidad, amenazada. En Temas Investigación y Ciencia: Monográfico 35 Biodiversidad.

Wilson, E. O. 1992. La diversidad de la vida. Editorial Crítica, Dracontos. Grupo Grijalbo-Mondadori. Barcelona. $411 \mathrm{pp}$.

\section{AGRADECIMIENTOS}

Diversas personas han aportado información y revisado el trabajo. En especial Borja Heredia aportó un informe inédito sobre el estado de la biodiversidad española, y Ángel Luque y José Templado proporcionaron valiosa información tanto publicada, como inédita. 
